\title{
The Danish National Patient Registry: a review of content, data quality, and research potential
}

This article was published in the following Dove Press journal:

Clinical Epidemiology

17 November 2015

Number of times this article has been viewed

\author{
Morten Schmidt ${ }^{1}$ \\ Sigrun Alba Johannesdottir \\ Schmidt ${ }^{1}$ \\ Jakob Lynge Sandegaard ${ }^{2}$ \\ Vera Ehrenstein' \\ Lars Pedersen' \\ Henrik Toft Sørensen' \\ 'Department of Clinical Epidemiology, \\ Aarhus University Hospital, \\ Aarhus, ${ }^{2}$ Department of Health \\ Documentation, State Serum Institute, \\ Copenhagen, Denmark
}

Correspondence: Morten Schmidt Department of Clinical Epidemiology, Aarhus University Hospital,

Olof Palmes Allé 43-45,

8200 Aarhus North, Denmark

Tel +4587168063

Fax +4587167215

Email morten.schmidt@clin.au.dk
Background: The Danish National Patient Registry (DNPR) is one of the world's oldest nationwide hospital registries and is used extensively for research. Many studies have validated algorithms for identifying health events in the DNPR, but the reports are fragmented and no overview exists.

Objectives: To review the content, data quality, and research potential of the DNPR.

Methods: We examined the setting, history, aims, content, and classification systems of the DNPR. We searched PubMed and the Danish Medical Journal to create a bibliography of validation studies. We included also studies that were referenced in retrieved papers or known to us beforehand. Methodological considerations related to DNPR data were reviewed.

Results: During 1977-2012, the DNPR registered 8,085,603 persons, accounting for 7,268,857 inpatient, 5,953,405 outpatient, and 5,097,300 emergency department contacts. The DNPR provides nationwide longitudinal registration of detailed administrative and clinical data. It has recorded information on all patients discharged from Danish nonpsychiatric hospitals since 1977 and on psychiatric inpatients and emergency department and outpatient specialty clinic contacts since 1995 . For each patient contact, one primary and optional secondary diagnoses are recorded according to the International Classification of Diseases. The DNPR provides a data source to identify diseases, examinations, certain in-hospital medical treatments, and surgical procedures. Long-term temporal trends in hospitalization and treatment rates can be studied. The positive predictive values of diseases and treatments vary widely $(<15 \%-100 \%)$. The DNPR data are linkable at the patient level with data from other Danish administrative registries, clinical registries, randomized controlled trials, population surveys, and epidemiologic field studies - enabling researchers to reconstruct individual life and health trajectories for an entire population.

Conclusion: The DNPR is a valuable tool for epidemiological research. However, both its strengths and limitations must be considered when interpreting research results, and continuous validation of its clinical data is essential.

Keywords: epidemiological methods, medical record linkage, registries, research design, validation studies

\section{Introduction}

As the role of routine computerized health data in epidemiological research is growing, ${ }^{1}$ there is a need to examine their strengths and limitations. ${ }^{2,3}$ Typical shortcomings of such data include limited linkage possibilities, incomplete temporal or geographic coverage, restriction to selected patient groups, and lack of systematic follow-up. ${ }^{4-7}$ Among the examples, the Dutch nationwide hospital registry has been in operation since 1963, but personal records are anonymized, and therefore not linkable to other 
data sources. ${ }^{4}$ Also, the United Kingdom's Clinical Practice Research Datalink has recorded detailed information on both diagnoses and prescriptions in primary care since 1987 but covers only part of the population and lacks information on patients who leave participating practices. ${ }^{8}$ In the United States, the collection of routine health data is restricted to specific age groups (eg, Medicare beneficiaries), ${ }^{6}$ income groups (eg, Medicaid beneficiaries), ${ }^{6}$ professions (eg, the Veterans Affairs), ${ }^{7}$ or members of private insurance plans (eg, Kaiser Permanente), ${ }^{9}$ often without the possibility of linkage or long-term follow-up.

In the Nordic countries, government-funded universal health care, combined with the tradition of record-keeping and individual-level linkage, has led to establishment of extensive networks of interlinkable longitudinal population-based registries covering entire nations. ${ }^{10,11}$ Patient registries with complete nationwide coverage and individual-level linkage potential have existed in Finland since 1969, ${ }^{12}$ in Sweden since 1987, ${ }^{13}$ in Iceland since 1999, ${ }^{14}$ and in Norway since 2008. ${ }^{15,16}$

The Danish National Patient Registry (DNPR) is one such population-based administrative registry, which has collected data from all Danish hospitals since 1977 with complete nationwide coverage since $1978 .{ }^{17-19}$ An epidemiologist setting out to use the DNPR must be familiar with the strengths and limitations of its data. Many studies have validated algorithms for identifying health events in the DNPR, but the reports are fragmented and no overview exists. Herein, we review the content and data quality of the DNPR and its potential as a research tool in epidemiology.

\section{Setting}

Denmark had 5,580,516 inhabitants in 2012, excluding inhabitants of Greenland and the Faroe Islands. ${ }^{20}$ Although these areas are part of the Kingdom of Denmark, they are not covered by the DNPR. Since 2007, the Danish healthcare system has had three administrative levels: ${ }^{10,21}$ 1) the state, responsible for legislation, national guidelines, surveillance, and health financing through the Ministry of Health; $2)$ the regions $(n=5)$, responsible for delivery of primary and hospital-based care; and 3 ) the municipalities $(n=98)$, responsible for a broad range of welfare services, including school health, child dental treatment, home care, primary disease prevention, and rehabilitation.

The Danish National Health Service provides taxsupported health care for the entire Danish population. ${ }^{10,21}$ Redistributionist taxation finances $\sim 85 \%$ of overall health care costs, including access to general practitioners (GPs), hospitals, outpatient specialty clinics, and partial reimbursement of prescribed medications. ${ }^{21}$ Of note, outpatient specialty clinics include contacts from hospital-based (ambulatory) specialty clinics but not from private practice specialists or GPs. Patients' out-of-pocket expenditures cover the remaining costs of medication and dental care. ${ }^{21}$ Except in emergencies, GPs (including on-call GPs) provide referrals to hospitals and specialists. ${ }^{21}$ Approximately 4,100 GPs and 4,600 dentists, as well as physiotherapists, chiropractors, and home nurses, work in the primary health care sector. ${ }^{21}$

The Danish Civil Registration System is a key tool for epidemiological research in Denmark. ${ }^{20,22}$ This nationwide registry of administrative information was established on April 2, 1968. ${ }^{20}$ It assigns a unique ten-digit Civil Personal Register (CPR) number to all persons residing in Denmark, allowing for technically easy, cost-effective, and exact individual-level record linkage of all Danish registries. ${ }^{20}$ The Danish Civil Registration System, which tracks and continuously updates information on migrations and vital status, permits long-term follow-up with accurate censoring at emigration or death. ${ }^{20}$

\section{DNPR overview}

\section{History}

In the early 1970s, most nonpsychiatric hospitals in Denmark established computerized Patient Administrative Systems (PASs). ${ }^{1}$ Initially, individual hospitals collected varying information. To ensure standardized data collection, the Danish Health and Medicines Authority developed a protocol for data collection, in which the unit of observation was the hospital discharge record of an individual patient. ${ }^{23}$ In 1976, all Danish counties (formerly the main administrative level, replaced by regions in 2007) were requested to submit these data to a central national hospital registry, which formed the basis for the DNPR (Danish, Landspatientregisteret). ${ }^{23}$ This registry was established in 1977 and achieved complete nationwide coverage in $1978 .{ }^{24}$

Since its establishment, different names have been used in the literature for the DNPR. Commonly used English terms include the Danish National Hospital Register, ${ }^{18}$ Danish National Health Registry, ${ }^{19}$ Danish National Patient Register, ${ }^{17}$ Danish Hospital Discharge Registry, ${ }^{25}$ and Danish National Registry of Patients. ${ }^{1}$ The official English name, as it appears in the registry declaration by the Danish Health and Medicines Authority, is the Danish National Patient Registry, DNPR. This term therefore will be used in this review.

\section{Aims}

The official aims of the DNPR are presented in Table $1 .{ }^{26}$ The primary aim is continuous monitoring of hospital 
Table I Aims of the Danish National Patient Registry

I. Form the basis for the Danish Health and Medicines Authority's hospital statistics

2. Form the basis for health economic calculations

3. Provide the Danish authorities with data to support hospital planning

4. Provide data to support the authorities responsible for hospital inspection

5. Monitor the frequency of various diseases and treatments

6. Provide a sampling frame for longitudinal population-based and clinical research

7. Facilitate quality assurance of Danish health care services

8. Provide hospital physicians with access to patient's hospitalization histories

and health services utilization for the Danish Health and Medicines Authority, thus providing a tool for health care planning. ${ }^{26}$ The registry is also increasingly used to monitor the occurrence of diseases and use of treatments, ${ }^{27}$ for quality assurance in the hospital sector, ${ }^{28}$ and for medical research. Since 2002, the DNPR has served as the basis for paying public and private hospitals via the DiagnosisRelated Group system. ${ }^{29,30}$ The registry also collects data for other health registries, including the Danish Psychiatric Central Research Register since $1995,{ }^{31}$ the Register of Legally Induced Abortions since 1995, ${ }^{32}$ the Medical Birth Registry since 1997, ${ }^{33}$ and the Danish Cancer Registry since $2004 .^{34}$

\section{Updates}

DNPR data are updated continuously. ${ }^{35}$ Each regional PAS is required by law to submit standardized data to the DNPR at least monthly, but in practice does so weekly or, for some hospitals, daily. As regional PASs may collect more information than is reportable to the DNPR, the contents of the PASs and the DNPR are overlapping but not identical. The overlapping data are referred to as the common content. The Danish Health and Medicines Authority reports all changes in the common content in its annual report - Common content for basic registration of hospital patients - which includes separate sections for users ${ }^{36}$ and developers. ${ }^{37}$ An overview of the registry's content and structure is also available online. ${ }^{26}$

Reporting to the DNPR became compulsory in 2003 for private hospitals and private outpatient specialty clinics, excluding private practice specialists and GPs. ${ }^{38,39}$ Private practice specialists are only obliged to report activities that are not covered by the health insurance scheme (Danish, Sygesikringen). Despite their increasing share in the health sector, the 249 private hospitals and clinics in Denmark generated only $2.2 \%$ of the total hospital activity in $2010 .{ }^{40}$
Registration of care provided by the private sector is mandatory, regardless of whether the referring hospital is public or private, whether out-of-pocket payments are involved, or whether patients are covered by a private health insurance. ${ }^{38,39}$ However, the reporting from private hospitals and clinics is generally considered incomplete. ${ }^{17,41}$

\section{DNPR content Type of data}

The content of the DNPR is structured, with each variable having a finite number of possible values. ${ }^{36,37}$ Information reported to the DNPR includes administrative data, diagnoses, treatments, and examinations (Table 2). ${ }^{26}$

Administrative data include personal and admission data. The personal data include patients' CPR numbers and municipality and region of residence. The admission data include hospital and department codes, admission type (acute or nonacute), patient contact type (inpatient, outpatient, or emergency department [ED]), referral information, contact reason, and dates of admission and discharge.

Diagnoses associated with each hospital contact are registered in the DNPR as one primary diagnosis and, when relevant, secondary diagnoses. ${ }^{36}$ The primary diagnosis is the main reason for the hospital contact. Secondary diagnoses supplement the primary diagnosis by identifying other relevant diseases related to the current hospital contact, eg, underlying chronic diseases. ${ }^{26,36}$ An exception (since 2009) is brain death (code: R991), which is registered as a diagnosis secondary to the primary underlying condition leading to brain death. ${ }^{36}$ In addition to primary and secondary diagnoses, the registry records referral, temporary, procedure-related, and supplementary diagnoses (Table 2 ). The discharging physician registers all diagnoses at the time of hospital discharge or at the end of an outpatient contact. However, outpatient and inpatient psychiatric contacts with long-term attendance are reported at least monthly. ${ }^{36} \mathrm{ED}$ contacts are registered as completed hospital contacts, regardless of whether patients are transferred to another hospital department. ${ }^{36}$

Treatments include information on surgery, other treatments (eg, invasive procedures, mechanical ventilation, dialysis, cancer treatments, and psychotherapy), anesthesia, and intensive care (Table 2).

Examinations include radiological procedures and other examinations (Table 2). The attending physician/surgeon registers treatment and examination codes immediately following their completion. Thus, each treatment and examination is assigned to its own exact date, independent of the dates of admission and discharge. 
Table 2 Content of the Danish National Patient Registry

Administrative data
CPR number
Residence
Hospital and department
Patient contact
Admission type
Referred from/referred
Referral period
Waiting time
Contact reason
Accident
Time specifications
Secondary diagnoses
Other administrative data

Treatments

Surgery (K)

Other treatments (B)

Anesthesia and intensive care $(\mathrm{N})$

\section{Examinations}

Radiological procedures (U)

Temporary examinations (W)

Other examinations (ZZ)
Unique ten-digit personal identification number assigned at birth or upon emigration

Municipality and region of residence

Hospital and department admitting the patient

Inpatient, outpatient (ambulatory), or emergency department contacts

Acute or nonacute

General practitioner, outpatient (ambulatory) clinic, other hospital departments, foreign hospital, no referral (eg, acute admission via ambulance), or death (only applies to "referred to" if death is declared during admission)

Period from referral date to start date for hospital contact

Period from referral date to start date for treatment

Reason for the hospital contact: diagnosis, accident, act of violence, suicide attempt, late complications, unknown (eg, unconscious patient), or other (rarely used)

Accident description, when an accident is the contact reason

Date and time of inpatient admission/discharge, start/end date for outpatient treatment, date of arrival to/ discharge from emergency department, and date of referral (if relevant)

Home visit (AAF6) or out-of-home visit (eg, drop-in center or prison service; AAF7)

Treatment status of cancers covered by national treatment guaranties: referred, examined, or under treatment

Main reason for hospitalization. When a patient is being examined and a diagnosis is not yet confirmed, a tentative "obs pro" (observation for) diagnosis may be used (the ICD-I0 "Z-codes")

Optional diagnoses supplementing the primary diagnosis by, eg, describing the underlying chronic disease that is related to the current patient contact

Diagnosis given by referring unit as the reason for referral

Diagnoses used only for ongoing nonpsychiatric outpatient contacts and never for completed contacts or for psychiatric contacts

Procedure-related complications, eg, perioperative bleeding or postoperative infections

Up to 50 codes supplementing the primary diagnosis, typically tentative diagnoses (eg, adding meningitis examination to the primary diagnosis disease of the central nervous system), drug abuse (eg, adding heroin to acute opioid intoxication), drug side effects (eg, adding acetylsalicylic acid to peptic ulcer disease), or cancer stage (eg, adding TNM stage to primary tumor diagnosis)

For example, surgery on the thyroid gland (KBA), lung (KGD), or coronary arteries (KFN)

Patient care: eg, dress a wound with sterile bandage (BNPA40) or supra pubic catheter change (BJAZI4) Invasive procedures: eg, implantation of pacemaker (BFCA0)/cardioverter-defibrillator (BFCB0) or radiofrequency ablation (BFFB)

Mechanical ventilation: invasive (BGDA0) or noninvasive (BGDAI)

Cancer/immune-modulating treatments: antibody or immune-modulating therapy (BOHJ), radiation therapy (BWG), stem cell or bone marrow transplantation (BOQE and BOQF), cytostatic treatment (BWHA), and biological therapies (BWHB)

Other medical treatment: eg, fibrinolysis (BOHAI) or initiation of parturition with prostaglandin (BKHD20)

Telemedicine: eg, patient counseling by phone (BVAA33A), email (BVAA33B), or video (BVAA33D)

Systemic psychotherapy: individual (BRSPI), couple (BRSP2), or family (BRSP3)

Physiotherapy or occupational therapy (BVD)

Other treatment examples: dialysis (BJFD), medical abortion (BKHD4), electroconvulsive therapy (BRXAI), total parenteral nutrition (BUALI), and acupuncture (BAFA80)

For example, during intensive care (NABB)

For example, angiography (UXA), computed tomography (UXC), magnetic resonance imaging (UXM), X-ray (UXR), and ultrasound scan (UXU)

Temporary classification of examinations

For example, planning rehabilitation (ZZ0I75X), distortion product otoacoustic emission (ZZ7307), and cardiotocography (ZZ4233)

For example, psychological evaluation (ZZ499I), semistructured diagnostic interview (ZZ4992), writing medical certificate (ZZ0I82), providing preoperative antibiotic prophylaxis (ZPLOC), and procedure cancellation due to nonappearance of the patient (ZPP30) 


\section{Changes in content over time}

Initially, the DNPR recorded information on all inpatient contacts only at nonpsychiatric (somatic) Danish departments, ${ }^{23}$ whereas psychiatric inpatient contacts were recorded in the Psychiatric Central Research Register from 1969 to 1995, after which it was merged with the DNPR. ${ }^{31}$ Registration of somatic outpatient contacts started in 1994 but was not complete (including the counties of Ribe, Ringkøbing, and Copenhagen) until 1995. Thus, since 1995, all psychiatric inpatient, psychiatric and somatic outpatient, and ED contacts in Denmark have also been reported to the DNPR. ${ }^{23}$

The personal data reported to the DNPR have remained unchanged since the registry's establishment in $1977,{ }^{36}$ but over time changes have been made to the admission data, diagnoses, treatments, and examinations. ${ }^{35}$

For the admission data, the first change occurred in 1987, whereby registration of patient contacts, referral information, and type of discharge was simplified (Table 3). Changes have been made almost annually thereafter, gradually expanding the registry's content as shown in Figure 1. The most recent changes to the admission data concerned type of admission and patient contact (Table 3). As of January 1, 2014, ED patients are no longer registered separately as "patient contact type 3" but instead as acute outpatients (ie, "admission type 1" and "patient contact type 2"), whereas other outpatients are registered as nonacute outpatients (ie, "admission type 2" and patient contact type 2). Thus, a patient contact in the DNPR was defined as an inpatient contact from 1977 through 1994; an inpatient, outpatient, or ED contact from 1995 through 2013; and as an inpatient or outpatient contact thereafter.

For diagnoses, it was originally possible to register up to 19 secondary diagnoses (ie, a maximum of 20 diagnoses per contact). Since 1995, the maximum number of recordable secondary diagnoses has increased to 99 in 1995-1998, 999 in 1999-2002, and 9,999 thereafter. Although in practice this

Table 3 Time line for patient contact and admission types in the Danish National Patient Registry

\begin{tabular}{lll}
\hline & Code & Registration period \\
\hline $\begin{array}{l}\text { Patient contact type } \\
\text { Inpatient }\end{array}$ & 0 & Jan I, 2002-ongoing \\
24 hour patient & 0 & Jan I, I977-Dec 3I, 200I \\
Daytime patient & $\mathrm{I}$ & Jan I, I977-Dec 31, I986 \\
Half-day patient & $\mathrm{I}$ & Jan I, I987-200 I \\
Outpatient & 2 & Jan I, 1987-ongoing \\
Overnight patient & 2 & Jan I, I977-Dec 3I, I986 \\
Emergency department patient & 3 & Jan I, I987-Dec 3I, 20I3 \\
Admission type & & \\
Acute & $\mathrm{I}$ & Jan I, I987-ongoing \\
Nonacute & 2 & Jan I, 1987-ongoing \\
\hline
\end{tabular}

means that there is no upper limit to the number of recordable secondary diagnoses, only the first 18 secondary diagnoses are subject to reimbursement by the Danish National Health Service. ${ }^{42}$ Since the adaption of the tenth revision of the International Classification of Diseases (ICD-10) in 1994, $23 \%$ of hospital contacts have had one or more secondary diagnoses recorded. The median number of secondary diagnoses per contact in this period was 1 (interquartile range: 1-2 diagnoses).

Surgeries have been reported to the DNPR since 1977. Starting in 1999, diagnostic examinations and treatments were included. ${ }^{26,35}$ It became mandatory to report on many medical treatments in 2001 (including cardiac, respiratory, kidney, and cancer treatments) and on radiological examinations in 2002. The results of examinations are not included in the DNPR (Table 2). Thus, the DNPR records when a patient undergoes magnetic resonance imaging, colonoscopy, biopsy, etc, but the findings are not registered explicitly. In some cases, however, findings may implicitly be inferred from the recorded diagnoses (eg, when an ulcer diagnosis follows procedure coding for gastroscopy).

\section{Number of patient contacts}

During 1977-2012, the cumulative Danish population numbered 8,342,199 persons. During this period, 8,085,603 distinct persons were registered in the DNPR at least once. Among these, 7,268,857 (90\%) persons were registered with an inpatient contact, 5,953,405 (74\%) persons with an outpatient contact, and 5,097,300 (63\%) persons with an ED contact. When excluding the unspecific Z-codes (factors influencing health status and contact with health services), the numbers of persons registered with inpatient, outpatient, and ED contacts were 4,610,123, 4,995,365, and 4,792,298, respectively. The distribution of all hospital contacts according to ICD category and patient contact type is shown in Table 4. The 25 most common ICD-10 diagnoses for each patient contact type are provided in Table 5.

\section{Classification systems The SKS browser}

The classifications used in the DNPR are provided in the Health Care Classification System (Danish, Sundhedsvæsenets Klassifikations System [SKS]). ${ }^{43}$ The SKS is a collection of international, Nordic, and Danish classifications. ${ }^{43}$ SKS codes contain up to ten alphanumeric characters, the first being a letter representing a primary group, following a monohierarchical classification system. ${ }^{43}$ Thus, diagnoses are registered under "D", surgery under "K", other treatments 


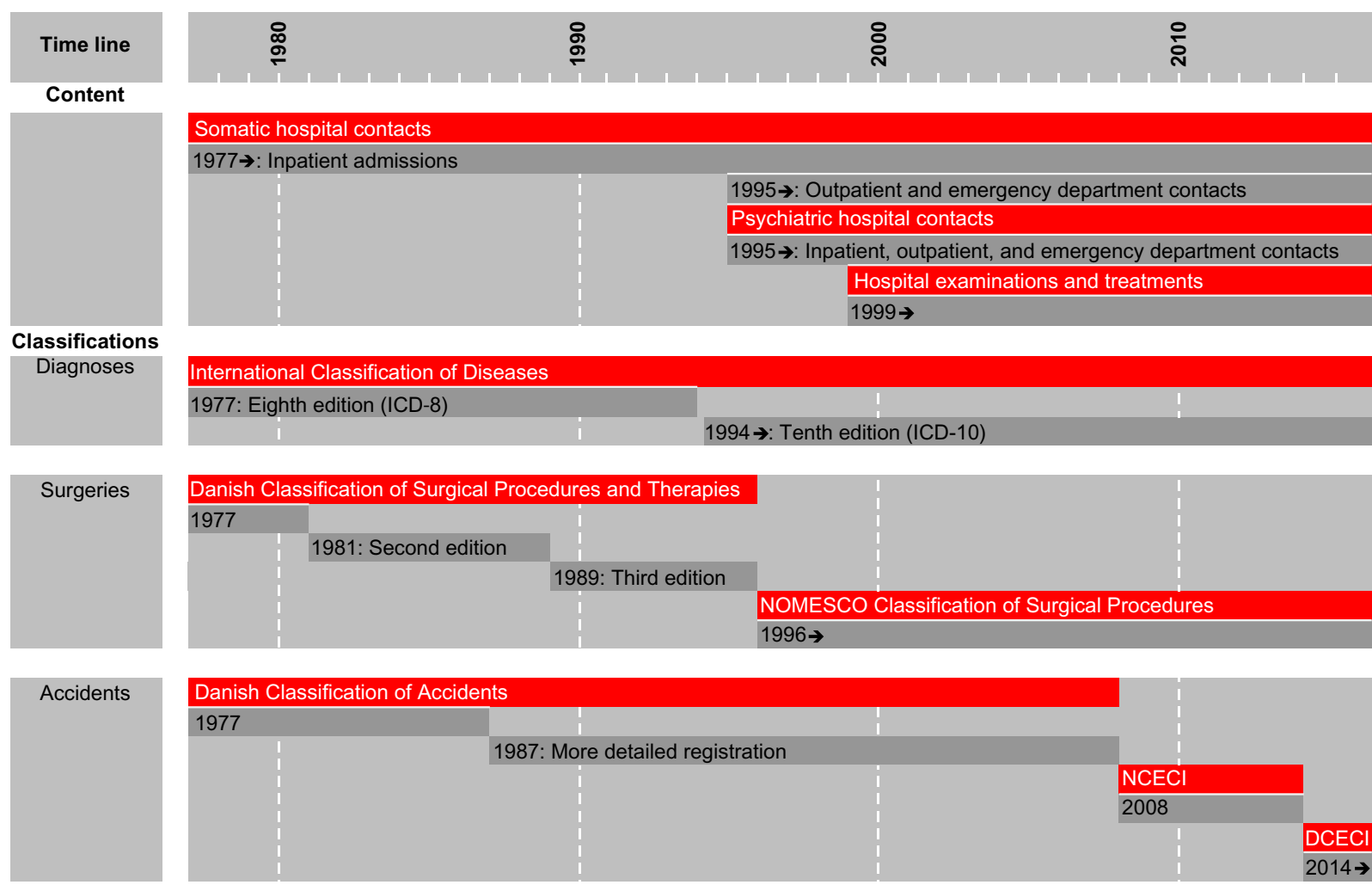

Figure I Timeline for the content and classification systems in the Danish National Patient Registry.

Abbreviations: DCECI, Danish Classification of External Causes of Injury; ed, edition; ICD, International Classification of Diseases; NCECI, Nordic Classification of External Causes of Injury; NOMESCO, Nordic Medico-Statistical Committee.

under "B", anesthesia under "N", and examinations under "U" or "ZZ" (Table 2). ${ }^{36}$

To facilitate the search for SKS codes, the Danish National Health and Medicines Authority maintains a user-friendly SKS browser (Figure 2), ${ }^{44}$ searchable by code, by free text, or by browsing. Searching for acute myocardial infarction codes can be done by entering "DI21" or by typing the Danish or Latin term in a full phrase (akut myokardieinfarkt) or a partial phrase (eg, infarctus myo). ${ }^{44}$ Manual browsing requires clicking the main group "Classification of diseases" (group D), then "Diseases of the cardiovascular system" (I), then "Ischemic heart disease" (I20-I25), and finally "Acute myocardial infarction" (I21). The SKS browser does not include historical codes ${ }^{44}$ but these are available online elsewhere. ${ }^{45}$

\section{Changes over time}

Over time, the DNPR has adopted different classification systems for diagnoses, surgeries, and accidents (Figure 1), whereas the classification systems for radiological procedures and in-hospital medications have remained unchanged since their introduction into the DNPR. ${ }^{26,36}$

Diagnoses were classified according to the ICD-8 until the end of 1993 and the ICD-10 thereafter. The three-digit
ICD-8 codes were used in a modified Danish version (with two supplementary digits), which explains in part why ICD-9 coding was never introduced in Denmark. Coding granularity improved in 1994 through introduction of the five-digit ICD-10 codes. Although the DNPR follows the current international standards for disease classification, the ICD-10 version used in Denmark often does not allow for identification of certain clinical details, such as disease severity. Supplementary codes (eg, the so-called "TUL" codes) sometimes allow for anatomical precision, eg, to identify location of a thrombosis or surgery site in right/left or upper/lower extremity, but these codes are used inconsistently. Sometimes, ABC extensions are added to specific diagnostic codes, eg, atrial fibrillation (I489B) and flutter (I489A), making the Danish version of the ICD-10 more detailed than the international ICD-10 but less detailed than the clinical modification of the ICD-10 (ICD-10-CM), which is not used in Denmark. ${ }^{46}$

Surgeries were coded according to the three consecutive editions of the Danish Classification of Surgical Procedures and Therapies, from 1977 to $1995 .{ }^{47}$ Since 1996, surgical procedures have been coded according to the Danish version of the Nordic Medico-Statistical Committee Classification of Surgical Procedures. ${ }^{48}$ 
Table 4 Number of patients registered in the Danish National Patient Registry according to disease categories and patient contacts, $1977-2012^{\mathrm{a}}$

\begin{tabular}{|c|c|c|c|c|c|c|}
\hline ICD-8 & ICD-IO & Disease categories & $\begin{array}{l}\text { Inpatient } \\
\text { contact, } \mathrm{n}(\%)\end{array}$ & $\begin{array}{l}\text { Outpatient } \\
\text { contact, n (\%) }\end{array}$ & $\begin{array}{l}\text { Emergency department } \\
\text { contact, } \mathbf{n}(\%)\end{array}$ & $\begin{array}{l}\text { Any patient } \\
\text { contact, } \mathrm{n}(\%)\end{array}$ \\
\hline All & All & All diseases & $7,268,857(100)$ & $5,953,405(100)$ & $5,097,300(100)$ & $8,085,603(100)$ \\
\hline $0-139$ & A00-B99 & $\begin{array}{l}\text { Certain infectious and parasitic } \\
\text { diseases }\end{array}$ & $80 I, 47 I(I I .0)$ & $232,080(3.9)$ & $104,089(2.0)$ & $975,286(\mid 2.1)$ \\
\hline $140-239$ & C00-D48 & Neoplasms & $\mathrm{I}, 308,247(\mathrm{I} 8.0)$ & $910,226(15.3)$ & $18,619(0.4)$ & I,599,930 (19.8) \\
\hline $280-289$ & D50-D89 & $\begin{array}{l}\text { Diseases of the blood and } \\
\text { blood-forming organs }\end{array}$ & $35 I, 455(4.8)$ & $146,420(2.5)$ & $13,779(0.3)$ & $416,132(5.1)$ \\
\hline $240-279$ & E00-E90 & $\begin{array}{l}\text { Endocrine, nutritional, and } \\
\text { metabolic diseases }\end{array}$ & $972,238(13.4)$ & 653,091 (11.0) & $69,610(1.4)$ & $\mathrm{I}, 232,964(15.2)$ \\
\hline $290-319$ & F00-F99 & Mental and behavioral disorders & $575,5 \mid 4(7.9)$ & $218,086(3.7)$ & $|37,7| \mid(2.7)$ & $743,981(9.2)$ \\
\hline $320-359$ & G00-G99 & Diseases of the nervous system & $514,425(7.1)$ & $504,543(8.5)$ & $90,232(1.8)$ & $840,500(10.4)$ \\
\hline $360-379$ & $\mathrm{H} 00-\mathrm{H} 59$ & Diseases of the eye and adnexa & $295,631(4.1)$ & $738,413(12.4)$ & $126,565(2.5)$ & $997,947(12.3)$ \\
\hline $380-389$ & $\mathrm{H} 60-\mathrm{H} 95$ & $\begin{array}{l}\text { Diseases of the ear and mastoid } \\
\text { process }\end{array}$ & $27 I, 495(3.7)$ & $547,612(9.2)$ & $42,307(0.8)$ & $750,109(9.3)$ \\
\hline $390-459$ & $100-199$ & Diseases of the circulatory system & I,97I,447 (27.I) & $\mathrm{I}, 106,198(18.6)$ & $311,333(6.1)$ & $2,3 \mid 2,646(28.6)$ \\
\hline $460-519$ & J00-J99 & Diseases of the respiratory system & $1,738,535(23.9)$ & $713,021(12.0)$ & $204,853(4.0)$ & $2,018,882(25.0)$ \\
\hline $520-579$ & K00-K93 & Diseases of the digestive system & $1,717,940(23.6)$ & I,I I6,975 (I8.8) & $174,675(3.4)$ & $2,229,186(27.6)$ \\
\hline $680-709$ & L00-L99 & $\begin{array}{l}\text { Diseases of the skin and } \\
\text { subcutaneous tissue }\end{array}$ & $421,034(5.8)$ & $434,280(7.3)$ & $190,607(3.7)$ & $824,052(10.2)$ \\
\hline $710-739$ & M00-M99 & $\begin{array}{l}\text { Musculoskeletal and connective } \\
\text { tissue disease }\end{array}$ & $\mathrm{I}, 178,743(16.2)$ & I,747,207 (29.3) & $440,731(8.6)$ & $2,387,728(29.5)$ \\
\hline $580-629$ & N00-N99 & $\begin{array}{l}\text { Diseases of the genitourinary } \\
\text { system }\end{array}$ & $1,527,088(21.0)$ & $1,132,468(19.0)$ & $123,847(2.4)$ & $2,066,692(25.6)$ \\
\hline $630-679$ & 000-099 & $\begin{array}{l}\text { Pregnancy, childbirth, and the } \\
\text { puerperium }\end{array}$ & $1,287,919(17.7)$ & $429,432(7.2)$ & $44,587(0.9)$ & $|, 321,98|(16.3)$ \\
\hline $760-779$ & P00-P96 & $\begin{array}{l}\text { Conditions originating in the } \\
\text { perinatal period }\end{array}$ & $468,787(6.4)$ & $75,901(1.3)$ & $\mathrm{I}, 867(0.0)$ & $490,506(6.1)$ \\
\hline $740-759$ & Q00-Q99 & $\begin{array}{l}\text { Congenital malformations and } \\
\text { deformations }\end{array}$ & $274,586(3.8)$ & $235,560(4.0)$ & $4, I 16(0.1)$ & $4 \mid 2,386(5.1)$ \\
\hline $780-799$ & R00-R99 & $\begin{array}{l}\text { Symptoms, signs, and findings } \\
\text { not classified elsewhere }\end{array}$ & I,952,537 (26.9) & $1,2 \mid 4,203(20.4)$ & $655,075(12.9)$ & $2,784,868(34.4)$ \\
\hline $800-999$ & S00-T98 & $\begin{array}{l}\text { External causes of injury and } \\
\text { poisoning }\end{array}$ & $2,184,899(30.1)$ & I,75I,282 (29.4) & $4,252,799(83.4)$ & $5,056,70 \mathrm{I}(62.5)$ \\
\hline E00-E99 & X0I-Y98 & $\begin{array}{l}\text { External causes of morbidity } \\
\text { and mortality }\end{array}$ & $669,066(9.2)$ & $756(0.0)$ & $27,230(0.5)$ & $692,424(8.6)$ \\
\hline Y00-Y99 & Z00-Z99 & $\begin{array}{l}\text { Factors influencing health } \\
\text { and contact with health services }\end{array}$ & $4,162,984(57.3)$ & $4,890,778(82.2)$ & I,894,89I (37.2) & $6,104,084(75.5)$ \\
\hline
\end{tabular}

Notes: ${ }^{\text {TT }}$ The disease categories are ordered according to the ICD-10. Both primary and secondary diagnoses were included. A person (ie, one Civil Personal Register number) can contribute in several diseases categories, but only once in each cell.

Abbreviation: ICD, International Classification of Diseases.

Accidents have been coded using the Danish Classification of Accidents. A detailed registration was introduced in 1987. The latest version of the classification, the Nordic Classification of External Causes of Injury, also included suicide attempts and violence. ${ }^{26}$ It was adopted in 2008 and used until a new Danish Classification of External Causes of Injury was incorporated in the SKS, in $2014 .{ }^{36,37}$ Although closely related to the Nordic classification in structure, the new Danish classification facilitates a simpler registration of external causes of injury.

Radiological procedures (without results) are coded according to the Danish Classification of Radiological Procedures (UX codes). This classification system follows the general principles used for registration of treatments in the SKS. ${ }^{36}$

In-hospital medication use (without dispensed dose or route of administration) is registered using different modules consistent with the Anatomical Therapeutic Chemical (ATC) classification system. Data on in-hospital medical treatment are not commonly used in research, except for drugs exclusively administered at hospitals, eg, fibrinolysis or cancer/immune-modulating treatments such as antibody, radiation, cytostatic, and biological therapies (Table 2). These drugs are primarily registered with a SKS treatment code, but their ATC codes can also be used as supplemental 
Table 5 The 25 most common ICD-10 diagnoses at the four-digit level in the Danish National Patient Registry, according to patient contact type, 1994-2012

\begin{tabular}{|c|c|c|c|c|c|}
\hline \multicolumn{2}{|l|}{ Inpatient contact } & \multicolumn{2}{|l|}{ Outpatient contact } & \multicolumn{2}{|c|}{ Emergency department contact } \\
\hline $\begin{array}{l}\text { Diagnosis } \\
\text { (ICD-10 code) }\end{array}$ & n (\%) & $\begin{array}{l}\text { Diagnosis } \\
\text { (ICD-10 code) }\end{array}$ & n (\%) & $\begin{array}{l}\text { Diagnosis } \\
\text { (ICD-10 code) }\end{array}$ & n (\%) \\
\hline Any & $4,610,123(100)$ & Any & $4,995,365(100)$ & Any & $4,792,298(100)$ \\
\hline $\begin{array}{l}\text { I. Spontaneous vertex } \\
\text { delivery }(\mathrm{O} 800)\end{array}$ & $466,723(10.1)$ & $\begin{array}{l}\text { Senile cataract, } \\
\text { unspecified }(\mathrm{H} 259)\end{array}$ & $287,008(5.7)$ & $\begin{array}{l}\text { Fracture of lower } \\
\text { end of radius (S934) }\end{array}$ & $590,608(12.3)$ \\
\hline $\begin{array}{l}\text { 2. Pneumonia, } \\
\text { unspecified (J/89) }\end{array}$ & $260,815(5.7)$ & Presbycusis $(\mathrm{H} 9 \mathrm{II})$ & $193,200(3.9)$ & $\begin{array}{l}\text { Open wound of finger(s) } \\
\text { without damage to nail }(56 \mid 0)\end{array}$ & $554,305(11.6)$ \\
\hline $\begin{array}{l}\text { 3. Abdominal pain, } \\
\text { unspecified (RI08) }\end{array}$ & $159,390(3.5)$ & $\begin{array}{l}\text { Unilateral or unspecified } \\
\text { inguinal hernia (K409) }\end{array}$ & $|78,8| \mid(3.6)$ & $\begin{array}{l}\text { Contusion of finger(s) } \\
\text { without damage to nail ( } \$ 600)\end{array}$ & $30 \mathrm{I}, 454(6.3)$ \\
\hline $\begin{array}{l}\text { 4. Angina pectoris, } \\
\text { unspecified (1209) }\end{array}$ & $147,605(3.2)$ & $\begin{array}{l}\text { Meniscus derangement } \\
\text { due to tear or injury (M232) }\end{array}$ & $157,750(3.2)$ & $\begin{array}{l}\text { Contusion of wrist and hand, } \\
\text { exclusion fingers ( } \mathrm{S} 602)\end{array}$ & $263,753(5.5)$ \\
\hline 5. Acute abdomen (RI00) & $146,264(3.2)$ & $\begin{array}{l}\text { Essential hypertension } \\
\text { (II09) }\end{array}$ & $132,992(2.7)$ & $\begin{array}{l}\text { Fracture of lower end } \\
\text { of radius (S525) }\end{array}$ & $250,339(5.2)$ \\
\hline $\begin{array}{l}\text { 6. Atrial fibrillation } \\
\text { and flutter (1489) }\end{array}$ & $142,849(3.1)$ & $\begin{array}{l}\text { Hearing loss, } \\
\text { unspecified }(\mathrm{H} 9 \mid 9)\end{array}$ & $126,037(2.5)$ & Contusion of knee (S800) & $243,863(5.1)$ \\
\hline 7. Concussion ( $\mathrm{S} 060)$ & 129,704 (2.8) & $\begin{array}{l}\text { Fracture of lower } \\
\text { end of radius (S525) }\end{array}$ & $123,682(2.5)$ & $\begin{array}{l}\text { Open wound of head, } \\
\text { part unspecified (SOI9) }\end{array}$ & $242,506(5.1)$ \\
\hline $\begin{array}{l}\text { 8. Syncope and collapse } \\
\text { (R559) }\end{array}$ & II 4,942 (2.5) & $\begin{array}{l}\text { Complete or unspecified } \\
\text { medical abortion (O049) }\end{array}$ & $|2|, 82 \mid(2.4)$ & Open wound of scalp (SOI0) & $24 \mid, 943(5.0)$ \\
\hline 9. Stroke, unspecified (1649) & II $2,366(2.4)$ & $\begin{array}{l}\text { Angina pectoris, } \\
\text { unspecified (1209) }\end{array}$ & $120,765(2.4)$ & $\begin{array}{l}\text { Contusion of other } \\
\text { and unspecified parts } \\
\text { of foot (S903) }\end{array}$ & $204,344(4.3)$ \\
\hline $\begin{array}{l}\text { 10. Gastroenteritis of } \\
\text { unspecified origin (A099) }\end{array}$ & $107,339(2.3)$ & $\begin{array}{l}\text { Tear of } \\
\text { meniscus (S832) }\end{array}$ & II 7,493 (2.4) & $\begin{array}{l}\text { Sprain and strain of } \\
\text { finger(s) }(\mathrm{S636})\end{array}$ & $199,784(4.2)$ \\
\hline $\begin{array}{l}\text { II. Unilateral or unspecified } \\
\text { inguinal hernia (K409) }\end{array}$ & $98,996(2.1)$ & $\begin{array}{l}\text { Abdominal pain, } \\
\text { unspecified (RI08) }\end{array}$ & || $7,38 \mid(2.3)$ & $\begin{array}{l}\text { Fracture of other } \\
\text { finger }(\mathrm{S} 626)\end{array}$ & $|7|, 706(3.6)$ \\
\hline $\begin{array}{l}\text { 12. Delivery by emergency } \\
\text { cesarean section (O82I) }\end{array}$ & $97,505(2.1)$ & $\begin{array}{l}\text { Varicose veins of lower } \\
\text { extremities (1839) }\end{array}$ & I I 6,957 (2.3) & $\begin{array}{l}\text { Contusion of shoulder } \\
\text { and upper arm (S400) }\end{array}$ & $169,022(3.5)$ \\
\hline 13. Volume depletion (E869) & $95,031(2.1)$ & $\begin{array}{l}\text { Disc disorders with } \\
\text { radiculopathy (M5II) }\end{array}$ & $1 \mid 3,217(2.3)$ & $\begin{array}{l}\text { Sprain and strain } \\
\text { of unspecified parts } \\
\text { of knee (\$836) }\end{array}$ & $163,976(3.4)$ \\
\hline $\begin{array}{l}\text { 14. Fracture of neck } \\
\text { of femur (S720) }\end{array}$ & $94,372(2.0)$ & $\begin{array}{l}\text { Asthma, } \\
\text { unspecified (1459) }\end{array}$ & $106,652(2.1)$ & Concussion (S060) & $162,564(3.4)$ \\
\hline $\begin{array}{l}\text { 15. Calculus of gallbladder, } \\
\text { no cholecystitis (K802) }\end{array}$ & $87,351$ ( 1.9$)$ & $\begin{array}{l}\text { Hyperplasia of } \\
\text { prostate (N409) }\end{array}$ & $106,459(2.1)$ & $\begin{array}{l}\text { Injury of conjunctiva } \\
\text { and corneal abrasion (S050) }\end{array}$ & $155,675(3.2)$ \\
\hline $\begin{array}{l}\text { 16. Spontaneous breech } \\
\text { delivery }(\mathrm{O} 802)\end{array}$ & $86,451$ ( 1.9$)$ & $\begin{array}{l}\text { Atrial fibrillation } \\
\text { and flutter (1489) }\end{array}$ & $105,710(2.1)$ & $\begin{array}{l}\text { Open wound of eyelid } \\
\text { and periocular area (SOII) }\end{array}$ & $150,449(3.1)$ \\
\hline $\begin{array}{l}\text { 17. Acute myocardial infarction, } \\
\text { unspecified (1219) }\end{array}$ & $84,800(1.8)$ & $\begin{array}{l}\text { Unspecified } \\
\text { hematuria (R3|9) }\end{array}$ & $105,548(2.1)$ & Contusion of thorax (S202) & $149,719(3.1)$ \\
\hline $\begin{array}{l}\text { 18. Cerebral infarction, } \\
\text { unspecified (1639) }\end{array}$ & $84,001(1.8)$ & $\begin{array}{l}\text { Internal derangement } \\
\text { of knee, unspecified (M239) }\end{array}$ & $104,986(2.1)$ & Contusion of elbow (S500) & $147,950(3.1)$ \\
\hline $\begin{array}{l}\text { 19. Complete or unspecified } \\
\text { medical abortion (O049) }\end{array}$ & $80,284(1.7)$ & $\begin{array}{l}\text { Carpal tunnel } \\
\text { syndrome (G560) }\end{array}$ & $96,247(1.9)$ & $\begin{array}{l}\text { Contusion of toe(s) without } \\
\text { damage to nail (S90I) }\end{array}$ & $133,673(2.8)$ \\
\hline $\begin{array}{l}\text { 20. Heart failure, unspecified } \\
\text { (1509) }\end{array}$ & $79,877(1.7)$ & $\begin{array}{l}\text { Calculus of gallbladder, } \\
\text { no cholecystitis (K802) }\end{array}$ & $94,599(1.9)$ & $\begin{array}{l}\text { Sprain and strain of } \\
\text { wrist (S635) }\end{array}$ & $133,174(2.8)$ \\
\hline $\begin{array}{l}\text { 21. Acute appendicitis, } \\
\text { unspecified (K359) }\end{array}$ & $74,769(1.6)$ & $\begin{array}{l}\text { Impingement syndrome } \\
\text { of shoulder (M754) }\end{array}$ & $91,306(1.8)$ & $\begin{array}{l}\text { Superficial injury of head, } \\
\text { part unspecified (S009) }\end{array}$ & I I 7,495 (2.5) \\
\hline 22. Constipation (K590) & $73,162(1.6)$ & COPD, unspecified (J449) & $89,555(1.8)$ & $\begin{array}{l}\text { Superficial injury of } \\
\text { scalp }(S 000)\end{array}$ & I I 7, I I 8 (2.4) \\
\hline 23. Acute cystitis (N300) & $72,768(1.6)$ & $\begin{array}{l}\text { Other primary } \\
\text { gonarthrosis (MI7I) }\end{array}$ & $89,528(1.8)$ & $\begin{array}{l}\text { Open wound of other parts } \\
\text { of wrist and hand (S6|8) }\end{array}$ & I I 6,600 (2.4) \\
\hline $\begin{array}{l}\text { 24. Vacuum extractor } \\
\text { delivery }(\mathrm{O} 8 \mid 4)\end{array}$ & $69,842(1.5)$ & Pain in limb (M796) & $86,225(1.7)$ & $\begin{array}{l}\text { Foreign body in } \\
\text { cornea (TI50) }\end{array}$ & $115,715(2.4)$ \\
\hline $\begin{array}{l}\text { 25. Essential hypertension } \\
\text { (II09) }\end{array}$ & $68,799(1.5)$ & Low back pain (M545) & $85,920(1.7)$ & $\begin{array}{l}\text { Sprain and strain of } \\
\text { cervical spine }(S \mid 34)\end{array}$ & II $4,4 \mid 9(2.4)$ \\
\hline
\end{tabular}

Notes: ${ }^{\mathrm{B}}$ Both primary and secondary diagnoses are included. Factors influencing health status and contact with health services (Z-codes) are not included. Abbreviation: ICD, International Classification of Diseases; COPD, chronic obstructive pulmonary disease. 

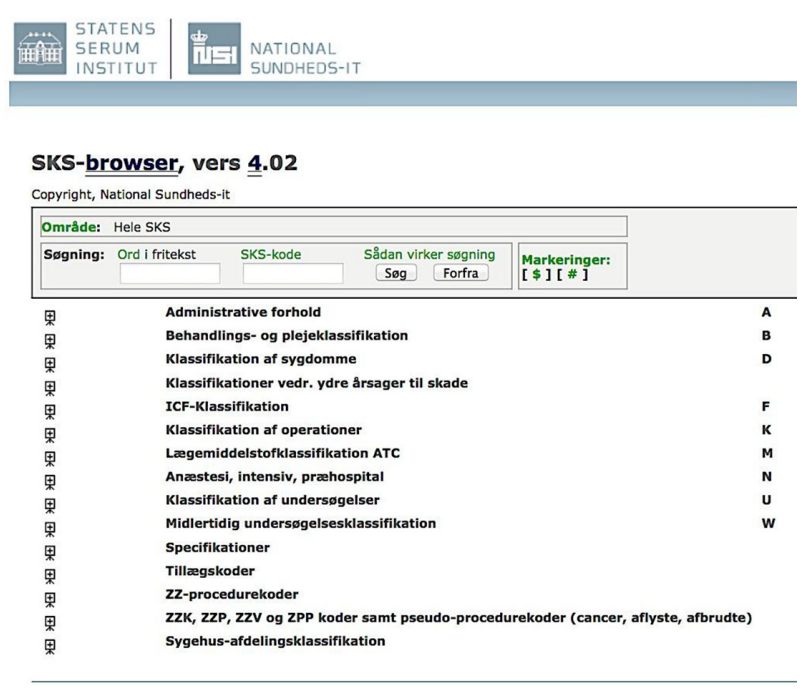

Figure 2 User interface of the Danish Health Care Classification System (SKS browser).

Notes: Available at http://www.medinfo.dk/sks/brows.php. English translation (consecutive line order): administrative data/classifications of treatment and care/ classification of diseases/classifications of external causes of injury/International Classification of Functioning (ICF)/classification of surgery/Anatomical Therapeutic Chemical (ATC) classification system/anesthesia, intensive care, prehospital care/ classification of examinations/temporary classification of examinations/specifications/ supplementary codes/ZZ-procedure codes/ZZK, ZZP, ZZV, and ZPP codes and pseudo procedure codes (cancer, cancelled, discontinued)/classification of hospitals and departments.

Abbreviation: SKS, Sundhedsvæsenets Klassifikations System.

codes (eg, fibrinolysis is covered by SKS code BOHA1 and ATC code B01AD).

\section{Data quality \\ Measurements of data quality}

The two most common measures of data quality are validity and completeness. ${ }^{49}$ By validity we refer to the extent to which a variable measures the intended construct. ${ }^{49}$ The positive predictive value (PPV) of registration is the most frequently reported measure of the validity of records in the DNPR. It is defined as the proportion of patients registered with a disease who truly have the disease and is usually estimated using medical record review as the reference standard to confirm the presence of disease. ${ }^{49}$ The term reference standard is used here, as medical record is not always considered the gold standard in validation studies, although one must assume that it is a better representation of the truth than the registry record.

Completeness refers to the proportion of true cases of a disease that is correctly captured by the registry. ${ }^{49}$ Completeness can be measured in relation to either all individuals in the general population with a specific disease or all patients admitted/treated for the specific disease. Completeness is largely determined by the registry's sensitivity and depends on the amount of missing data. ${ }^{49}$ Since no complete reference source exists, it is difficult to estimate the overall completeness of registry data relative to the general population. Data completeness depends on hospitalization patterns and diagnostic accuracy. Thus, conditions such as nonfatal myocardial infarction or hip fracture, which should always lead to a hospital encounter, are registered consistently in the DNPR. In contrast, lifestyle risk factors (overweight, smoking, excessive alcohol consumption, and physical inactivity) and conditions as hypertension or uncomplicated diabetes are often treated by GPs and are thus not completely registered.

\section{Overall data quality}

After receiving data from the hospitals, the DNPR automatically checks for missing codes, incorrect digits, errors in CPR numbers, and inconsistencies between diagnoses and sex. ${ }^{24}$ In case of errors, the records are returned to the source hospital for correction. ${ }^{24}$

The Danish Health and Medicines Authority has examined the PPVs of personal data, admission data, and diagnoses in the DNPR three times, using medical record review as the reference standard. ${ }^{24,50,51}$ The first such validation was performed in 1980 as a pilot study of 1,000 randomly sampled discharges from a single hospital (Hillerød Hospital). ${ }^{50}$ The study concluded that the validity of primary diagnoses in the DNPR was not sufficient for research. ${ }^{50}$ The secondary study validated 1,094 random discharges from a 1990 nationwide sample and found high overall correlation between admission and discharge data in the DNPR and medical records. ${ }^{24}$ The proportion of incorrect registrations was $1.4 \%$ for admission type, $8.1 \%$ for contact reason, $0.8 \%-8.7 \%$ for accident registration (lowest for work-related accidents), $14.8 \%$ for the "referral to" variable, and $1.5 \%$ for date of discharge. The "referral from" data were incorrect among $11.5 \%$ of nonacute patients. However, due to differing guidelines for reporting this variable, there was considerable regional variation in its validity. In the study, diagnoses and surgical procedures were categorized according to five clinical specialties covering $85 \%$ of all nonpsychiatric discharges (Table 6 ). A comparison of various primary diagnoses showed correct categorization at the five-digit level for $73 \%$ of all cases, increasing to $83 \%$ when alternative diagnoses were accepted. Substantial variation was observed between different clinical specialties, with the lowest PPV for medical diagnoses (66\%) and the highest PPV for diagnoses associated with orthopedic surgery (83\%). For all specialties, the proportion of correct diagnoses increased substantially when the comparison was made at the three-digit rather than at the five-digit level. It increased 
Table 6 Summary results from the Danish Health and Medicines Authority's evaluation of diagnoses in the Danish National Patient Registry in 1990 according to clinical specialties

\begin{tabular}{|c|c|c|c|c|}
\hline \multirow[t]{3}{*}{ Clinical specialty } & \multicolumn{4}{|c|}{ Positive predictive value of correct primary diagnoses } \\
\hline & \multicolumn{2}{|c|}{ Five-digit diagnosis codes } & \multicolumn{2}{|c|}{ Three-digit diagnosis codes } \\
\hline & $\begin{array}{l}\text { Primary diagnosis } \\
\text { alone (\%) }\end{array}$ & $\begin{array}{l}\text { Primary + two secondary } \\
\text { diagnoses (\%) }\end{array}$ & $\begin{array}{l}\text { Primary diagnosis } \\
\text { alone (\%) }\end{array}$ & $\begin{array}{l}\text { Primary + two secondary } \\
\text { diagnoses (\%) }\end{array}$ \\
\hline Medicine & 66 & 72 & 73 & 81 \\
\hline Pediatrics & 74 & 80 & 82 & 89 \\
\hline General surgery & 77 & 82 & 84 & 89 \\
\hline Gynecology/obstetrics & 77 & 88 & 83 & 94 \\
\hline Orthopedic surgery & 83 & 85 & 89 & 91 \\
\hline Overall & 73 & 80 & 81 & 88 \\
\hline
\end{tabular}

even further when secondary diagnoses were also included (Table 6). The third validation study included 420 random discharges from a nationwide sample in 2003 and focused only on admission and discharge data. ${ }^{51}$ The proportion of incorrect registrations in this sample was 3\% for admission type and $8 \%$ for referral type. Data on admission/discharge dates, hospital/department codes, and CPR numbers were accurate. $^{51}$

\section{Systematic review of validated variables}

The data quality of individual variables in the DNPR has been examined on an ad hoc basis..$^{25,52-164}$ To provide researchers with an overview of such studies, we performed a systematic review, aiming to create a bibliography of validated administrative data, diagnoses, treatments, and examinations in the DNPR.

Figure S1 shows a flowchart for the review process, including the search strategy. We searched MEDLINE (PubMed) and the Danish Medical Journal (http://ugeskriftet. dk/udgivelser) using the Danish and the various English names for the DNPR. One author (MS) screened titles and abstracts, and when necessary the full-text papers, for inclusion in the bibliography. Because validation is often a secondary study aim and therefore not highlighted in titles, abstracts, or keywords of papers, even a comprehensive systematic search cannot identify all relevant papers. We therefore also searched the reference lists of the retrieved papers for potentially relevant articles. Finally, we included additional studies known to us beforehand. We included all studies written in English or Danish, regardless of characteristics, such as publication status or year.

Two authors (MS and SAJS) independently extracted the following data from all included papers: patient contact type (inpatient, outpatient, or ED), diagnosis type (primary vs secondary), codes/algorithms used, measure of validity (PPV/negative predictive value), measure of completeness (sensitivity/specificity), the reference standard used, and results (absolute numbers, proportions, and confidence intervals [CIs]). Any disagreements were resolved by consensus. When patient contact, diagnosis type, or codes were not specified, we contacted the corresponding authors for this information. Unspecified patient type included most often both in- and outpatient diagnoses. Unspecified diagnosis type included most often both primary and secondary diagnoses. Unconfirmed data were categorized as not available (n/a). We used extracted information as well as more detailed information from selected studies to illustrate the use of various algorithms over time and to discuss methodological considerations, in particular information bias.

Our review showed that several different methods had been used to calculate CIs for proportions. Moreover, studies varied with respect to the number of decimal points reported for CIs, while some studies failed to report CIs. To permit direct comparisons among study results, we recalculated all proportions based on the absolute numbers provided in the papers. We used Wilson's score methods to calculate CIs with one decimal point precision. ${ }^{165}$ When lack of absolute numbers precluded recalculations, we presented the results as reported in the original reference.

We identified 114 papers, validating 1-40 codes/ algorithms each and 253 in total. The bibliography of validated variables is provided in Table S1. The variables are listed in the table according to the SKS coding (ie, ICD-10 codes for diagnoses and Nordic Medico-Statistical Committee codes for surgeries) and within each variable according to study period. Recalculation of all proportions reported was possible for $89 \%(102 / 114)$ of all studies.

We found that the PPVs of the reported diagnoses in the DNPR ranged from below $15 \%{ }^{137}$ to $100 \%{ }^{58,97}$ Some of this variation (both intervariable and intravariable variation) may result from different reference standards used. The majority 
of variables were examined in cross-sectional studies using medical record review as the reference standard. However, several other reference standards have also been used, including patient interviews, ${ }^{84,146}$ clinical registries, ${ }^{32,57,78,89,142}$ the Danish Cancer Registry, ${ }^{59,60,64,67}$ a military conscription research database, ${ }^{116}$ the Clinical Laboratory Information System Database, ${ }^{72,73,114}$ the Danish National Pathology Registry and Data Bank, ${ }^{120}$ the hospital pharmacy systems, ${ }^{160}$ the Danish prescription registries, ${ }^{79,83}$ GP verification, ${ }^{75}$ radiology reports, ${ }^{111,118}$ and autopsy reports. ${ }^{110,141}$ Our review revealed variation in study settings and calendar year. The study setting is important to consider, as the PPV depends on the prevalence of disease and therefore on the data's department of origin. Thus, restriction to specialized departments, eg, rheumatology departments when examining the validity of a rheumatoid arthritis diagnosis, likely results in higher PPVs. ${ }^{126}$ Similarly, the calendar year may affect the quality of variables, given the continuous improvement in diagnostic criteria and procedures used. As examples, the validation studies indicate a temporal increase in the PPV of ulcer disease (from $84 \%$ during $1997-2001^{119}$ to $98 \%$ during 1998-2007 ${ }^{58}$ ) and of myocardial infarction (from 92\% during $1979-1980,{ }^{100} 94 \%$ during $1982-1991,{ }^{99}$ to almost $100 \%$ during $1996-2009^{97}$ ). Improvements in variable completeness over time have also been documented for, eg, bacteremia (from $4.4 \%$ in $1994,{ }^{25} 25.1 \%$ in $2000,{ }^{55}$ to $35.1 \%$ in $2011^{55}$ ).

We found that the definition of a disease in registry data is not always based on ICD codes alone but may require algorithms that combine a diagnosis with admission data (eg, admission type, patient contact, and department specialty), other diagnostic specification (such as primary vs secondary diagnoses), procedures, in-hospital medical treatment (eg, chemotherapy), prescription use, previous medical history (to identify incident events), time since first diagnosis or metastasis (to identify recurrent events), pathology data (for tumor genotypes), ${ }^{166}$ or other registry data (eg, laboratory ${ }^{167}$ and cancer data ${ }^{34}$ ). As an example, a validation study of recurrent venous thromboembolism tested different algorithms based on the inpatient vs outpatient diagnoses, presence or absence of an ultrasound or computed tomography (CT) scan during admission, and postdischarge anticoagulant drug use. ${ }^{112}$ Based on the results of that study, a case of venous thromboembolism recurrence was defined as an inpatient diagnosis of deep venous thrombosis or pulmonary embolism recorded $>3$ months after the incident venous thromboembolism event among patients with an ultrasound or CT scan performed during admission (PPV $=79 \%$ ). ${ }^{112}$ An algorithm for colorectal cancer recurrences combines metastasis and chemotherapy codes in the DNPR with cancer recurrence codes in the Danish National Pathology Registry (PPV $=86 \%$; sensitivity $=95 \%) .{ }^{61}$

Lack of completeness of the DNPR in capturing certain conditions can sometimes be compensated by data linkage to other routine registries. Diabetes can be identified from at least one outpatient dispensation record for insulin or an oral antidiabetic drug (in the Danish prescription registries ${ }^{168}$ ) and/or by an inpatient or outpatient hospital diagnosis of type 1 or type 2 diabetes in the DNPR.${ }^{76}$ Recent studies have supplemented the algorithm with data on glycosylated hemoglobin $\mathrm{A}_{1 \mathrm{c}}$ level of $\geq 6.5 \%$ from the Clinical Laboratory Information System Database, increased specificity by excluding metformin-treated patients with polycystic ovarian syndrome, ${ }^{169}$ and differentiated type 1 and type 2 diabetes using information on age at diagnosis combined with insulin monotherapy. ${ }^{76}$

The large variation in data validity found in our review underscores the need to validate diagnoses and treatments before using DNPR data for research. Furthermore, validation studies may need updates, as newer diagnostic criteria and procedures may differ from those used in older validation studies.

\section{DNPR as a research tool Health events}

Potential uses of the DNPR, according to study design, are presented in Table 7. Patient cohorts of interest may be identified, along with their medical history and outcomes. Thus, the DNPR may provide data on diseases, ${ }^{170,171}$ treatments, ${ }^{172}$ and diagnostic examinations as exposures. Seasonal variation as an exposure has also been examined. ${ }^{173}$

Furthermore, the DNPR allows for identification of disease occurrence in the general population (risk studies), ${ }^{174}$ where the exposure information could originate from other data sources involving primary or secondary data collection, eg, military conscription cohorts ${ }^{175}$ or population-based health surveys such as the Danish Health Examination Survey, ${ }^{176}$ the "How Are You?" study, ${ }^{177}$ the Danish Diet, Cancer and Health study, ${ }^{178}$ the Soon Parents cohort, ${ }^{179}$ the Glostrup Population Studies, ${ }^{180}$ and the Copenhagen City Heart study. ${ }^{181}$ Extraordinary long-term follow-up ( $>35$ years) for lifestyle-associated diseases is feasible. ${ }^{175}$

Using techniques similar to that in risk studies, the DNPR can be used to study outcomes in well-defined patient groups 
Table 7 Use of the Danish National Patient Registry according to study design

\begin{tabular}{ll}
\hline Cohort studies & Identifying study cohorts from hospitalized patients, the general population (assessed from registries or in combination \\
with primary data collection), and family cohorts (constructed through linkage to the Danish Civil Registration System) & Identifying study exposures related to diseases, treatments, examinations, and seasonality \\
& Identifying disease occurrence in the general population (eg, associated with lifestyle factors identified from health surveys) \\
& or family cohorts \\
Identifying disease outcome (recurrence or complications) in patients identified from the DNPR itself, clinical registries, \\
or randomized trials \\
Identifying health care utilization rates through counting frequency of inpatient/outpatient and planned/unplanned contacts \\
Identifying temporal trends in disease incidence and use of treatments and diagnostic procedures \\
Identifying cases (and exposure from the DNPR, other registries, health surveys, or primary data collection). Risk-set \\
sampling is possible through linkage to the Danish Civil Registration System \\
Identifying patient's medical history at study entry according to diagnoses (index disease and comorbidities), treatments \\
(in-hospital medical treatment, surgical procedures, anesthesia, and intensive care), and diagnostic procedures \\
Identifying variations in health care and outcomes at the population level
\end{tabular}

Abbreviation: DNPR, Danish National Patient Registry.

(eg, diagnostic examinations, ${ }^{182}$ recurrence,,${ }^{112}$ and complications ${ }^{183}$ ) and prognostic factors. ${ }^{170}$ These patient groups may be identified from the DNPR itself, other registries, or surveys. Most recently, the DNPR has also been used to gather long-term follow-up data for randomized controlled trials using clinically driven outcome detection. ${ }^{184}$ The automated event-detection feature of the DNPR allows for large, lowcost randomized trials that reflect daily clinical practice, cover a broad range of patients and end points, and include lifelong follow-up. ${ }^{183,185-187}$ As with cohort studies, DNPR data may be used to identify exposures and cases/outcomes in casecontrol studies ${ }^{112,188,189}$ and ecological studies ${ }^{182}$ (Table 7).

\section{Health care planning}

The administrative data related to each patient contact allow for studies of health care utilization and how health care planning may affect patient outcomes. As an example, admission rates for the most common medical conditions in Denmark have been found to be higher during the regular office hours than during the weekend hours. ${ }^{190}$ However, admissions during the weekend hours have been associated with higher mortality rates (weekend nighttime hours $>$ weekend daytime hours $>$ weekday out-of-hours $>$ weekday office hours). ${ }^{190}$

\section{Record linkage}

The availability of patient-identifiable data in the DNPR makes it technically easy to link to other Danish data sources using the CPR number. ${ }^{20}$ Because Denmark's registries are numerous and far reaching even by the high standards of the Nordic countries, ${ }^{22,191}$ additional information on, eg, cancer staging, ${ }^{34}$ laboratory test results,${ }^{167}$ general practice utilization, ${ }^{192}$ socioeconomic data, ${ }^{193-196}$ prescription use, ${ }^{197}$ all-cause mortality, ${ }^{20}$ and cause-specific mortality ${ }^{198}$ can easily be obtained to supplement the DNPR. Figure 3 shows the time line for the DNPR relative to selected administrative and clinical registries in Denmark, illustrating the potential for record linkage by calendar year. As shown, nationwide data can be obtained on, eg, all twins in Denmark since 1870 (the Danish Twin Registry), ${ }^{199}$ specific causes of death since 1943 (the Danish Register of Causes of Death), ${ }^{198}$ detailed cancer diagnoses since 1943 (the Danish Cancer Registry), ${ }^{34}$ migration and vital status since 1968 (the Danish Civil Registration System), ${ }^{20}$ personal income since 1970 (the Income Statistics Registry), ${ }^{195}$ labor market statistics and health services since 1980 (the Integrated Database for Labour Market Research ${ }^{193}$ and Danish National Health Service Register), ${ }^{192}$ education since 1981 (the Population's Education Register), ${ }^{194}$ prescribed medications since 1995 (the Danish National Prescription Registry), ${ }^{168}$ and patient tissue samples and blood transfusions since 1997 (the Danish National Pathology Registry and Blood Transfusion Databases). ${ }^{166}$ The Danish clinical registries constitute the infrastructure of the National Clinical Quality Databases and the Danish Multidisciplinary Cancer Groups. ${ }^{200}$ The clinical registries contain information about individual patients used for quality improvement, research, and surveillance purposes. ${ }^{200}$ Linkage to one or more of the current 69 clinical registries thus provides detailed information on a range of procedures (eg, hip arthroplasty and hysterectomy) and diseases (eg, heart failure, stroke, diabetes, and various malignant diseases; Figure 3). ${ }^{200,201}$ Finally, individual-level linkage to data from randomized controlled trials, population surveys, and epidemiologic field studies is possible as previously described.

\section{Methodological considerations}

Methodological considerations related to the internal validity of cohort studies conducted within the DNPR are summarized 


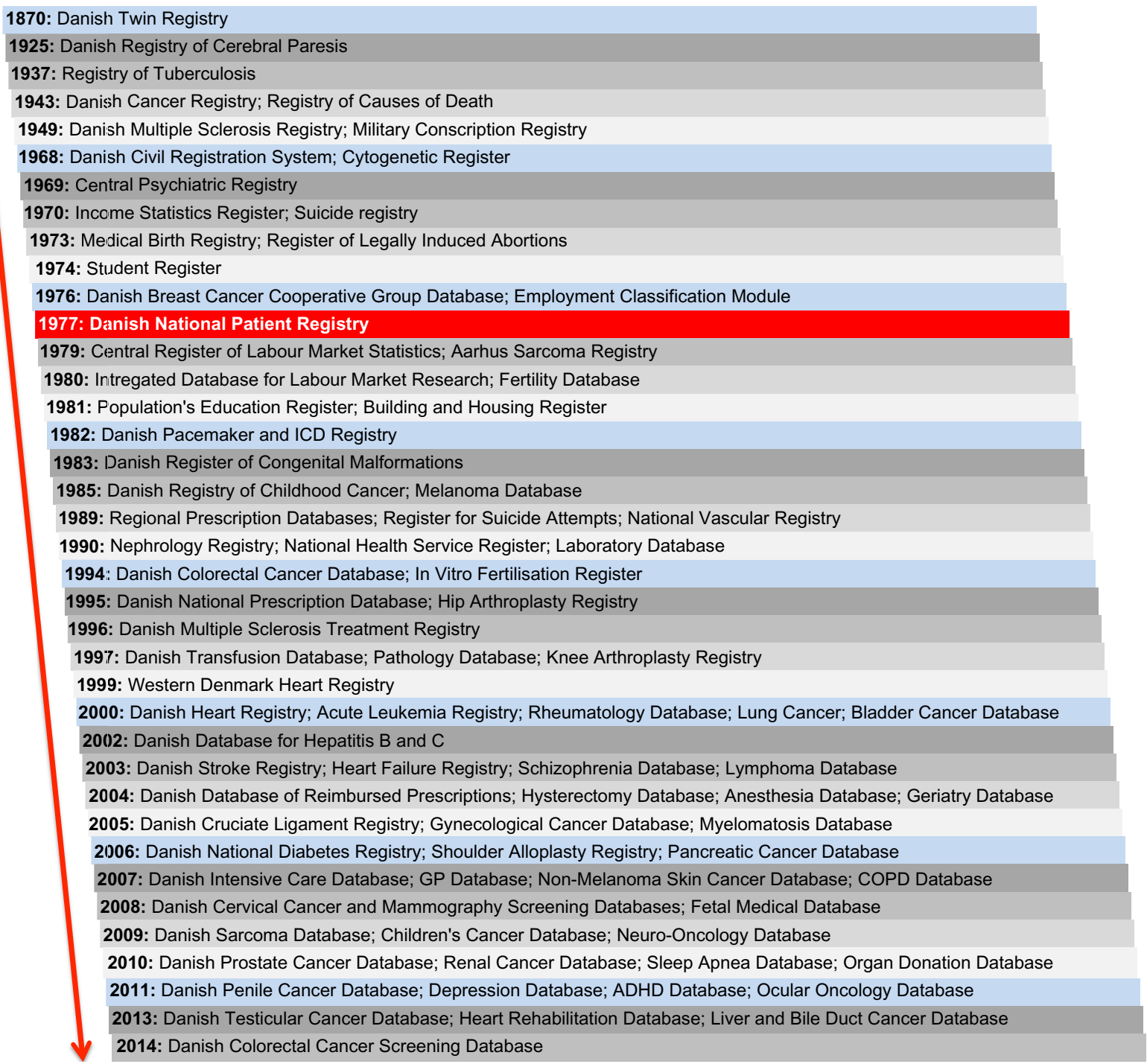

Figure 3 Timeline for the initiation of selected Danish registries linkable to the Danish National Patient Registry.

Abbreviations: ADHD, attention deficit hyperactivity disorder; ICD, International Classification of Diseases; GP, general practitioner; COPD, chronic obstructive pulmonary disease.

subsequently and in Table 8 . We also address the special methodological problems that relate to studies of temporal health trends.

\section{Precision}

The nationwide coverage since 1978 provides sample sizes that permit studies of rare diseases, disease complications, and effects in subgroups of patients (effect modification and interactions). Of note, very rare diseases may still be difficult to study because of the relatively small size of the Danish population..$^{202}$

\section{Selection bias}

Appropriate population-based study designs can reduce selection biases in cohort studies for three reasons. First, the
Danish population has a relatively stable and homogeneous demography with regard to race and religion. Second, the universal health care system (and small private hospital sector $)^{40}$ prevents selection bias arising from selective inclusion of specific hospitals, health insurance systems, income levels, or age groups. Third, virtually complete follow-up of all patients (with no unrecorded dropouts) is possible because the Danish Civil Registration System records vital status and migrations on a daily basis. ${ }^{20}$ Still, the cohort represented in the DNPR is only unselected for diseases that always require hospital treatment. For diseases that can be treated in general practice, cases included in the DNPR to some degree represent a selected patient group, with either high severity of the disease in question (eg, herpes zoster infections, obesity, diabetes, and hypertension) or severe comorbidity leading 
Table 8 Methodological considerations related to the internal validity of cohort studies conducted with data from the Danish National Patient Registry

\begin{tabular}{ll}
\hline Precision & $\begin{array}{l}\text { The large nationwide sample permits studies of } \\
\text { rare diseases, disease complications, and treatment } \\
\text { effects in subgroups of patients }\end{array}$ \\
Selection bias & $\begin{array}{l}\text { The population-based coverage, within a universal } \\
\text { health care system with virtually complete follow-up } \\
\text { of all patients owing to the Danish Civil Registration } \\
\text { System, reduces the risk of selection biases }\end{array}$ \\
Information bias & $\begin{array}{l}\text { The risk of misclassification warrants validation of } \\
\text { all variables used for research } \\
\text { Confounding }\end{array}$ \\
& $\begin{array}{l}\text { The registrations of diagnoses, treatments, and } \\
\text { examinations for all hospital contacts may provide } \\
\text { data on potential confounding factors. Seasonality } \\
\text { may be controlled in the studies of infectious disease }\end{array}$
\end{tabular}

to a lower threshold for hospital admission compared with patients without comorbidity (eg, pneumonia in transplant patients vs in young otherwise healthy adults).

\section{Information bias}

Although it is obvious that registration and retrieval of patient information from the DNPR must be based on correct SKS codes, this task is not always easy. The SKS includes many codes that might not be mutually exclusive from a clinical point of view. For many diagnoses, it is thus necessary to be aware of potential differences in registration practice among hospital departments ${ }^{24}$ and over time. ${ }^{122,170,203}$

Before engaging in extensive retrieval and analysis of data, it is therefore important to consult clinicians from the relevant specialty to learn about current and previous coding practices. As an example, atrial fibrillation and atrial flutter have separate codes at the four-digit level. However, a large proportion of all diagnoses for atrial fibrillation or flutter are registered as "not elsewhere specified" (Danish, uden nærmere specifikation). Since $\sim 95 \%$ of all I48 codes correspond to atrial fibrillation and only $5 \%$ to atrial flutter, ${ }^{104}$ use of the unspecified code will increase the sensitivity of the DNPR-based definition of atrial fibrillation but reduce its specificity. Hence, DNPR studies on risk of atrial fibrillation are often limited by considering atrial fibrillation and flutter as one disease entity. ${ }^{174}$ Another example is ICD-10 diagnoses of stroke (I60-I64). Approximately one-third of the cases are registered as unspecified stroke (I64), ${ }^{204}$ and among these, two-thirds are ischemic strokes. ${ }^{91}$ Inclusion of unspecified diagnoses will increase sensitivity but reduce specificity of stroke subtypes.

The introduction of the Diagnosis-Related Group system in $2002^{29,30}$ regarding payment to public hospitals may have resulted in more complete registration. However, it may also have affected coding practices for some diseases and certain types of treatments. Private hospitals and clinics are potential sources of underreporting. ${ }^{40}$ Although it has been mandatory for private health care providers to report all activities since 2003, and the Danish Health and Medicines Authority runs information campaigns to promote registration, ${ }^{38}$ registration from private hospitals and clinics remains incomplete. ${ }^{17,41}$ Private hospitals offer services paid by taxes due to the rules of "free hospital choice" or as part of an agreement with a region, as well as services paid privately either by insurance companies or private parties. ${ }^{21,40}$ Services paid for by private parties have the highest degree of incomplete registration.

In contrast to validity, the completeness of diagnoses is often higher in the DNPR than in the clinical registries. ${ }^{89,100,164,205,206}$ This higher completeness is expected since many clinical registries receive data from the DNPR. Another reason is that the law requires the national clinical registries to cover only $90 \%$ of patients with a given condition. ${ }^{207}$ Moreover, the degree of completeness varies among and within clinical registries over time. ${ }^{164,208}$

\section{Confounding}

Nonrandomized studies are susceptible to confounding by known and unknown factors. ${ }^{209}$ Therefore - irrespective of data source - the potential for confounding always needs to be addressed in the study design or analysis. The DNPR provides an opportunity to obtain information on many potential confounders, particularly comorbidities. ${ }^{58,210}$ The possibility of identifying such covariables from patients' history of hospital encounters (back to 1977) rather than short-fixed historical windows may also result in less biased estimates. ${ }^{211}$ Still, it should be kept in mind that incomplete registration of some diagnoses and missing data on other characteristics (eg, lifestyle risk factors $^{212}$ ) may leave substantial residual and unmeasured confounding.

\section{Temporal health trends}

As data in the DNPR currently span almost four past decades, the registry is a unique data source to monitor long-term temporal trends in use of diagnostic procedures (eg, cardiac CT angiography), ${ }^{164}$ treatments (eg, use of implantable cardioverter-defibrillators), ${ }^{213}$ and disease incidence (eg, myocardial infarction). ${ }^{27,170}$ Related particularly to disease incidence, however, a number of methodological problems must be considered. 
First, the DNPR only covers patients with disease episodes associated with hospital contact and thus not necessarily the total number of patients with a given disease (as described previously).

Second, lack of information on deaths occurring outside the hospital among persons with no previous hospital contact for a given disease may lead to underestimation of both the disease incidence and the disease-specific mortality. This problem is particularly important for acute critical events such as myocardial infarction. ${ }^{170}$ Still, it should be noted that a person is not considered legally dead in Denmark before a physician has confirmed clear signs of death. Thus, all patients dying in an ambulance or otherwise arriving at a hospital with no signs of life are also admitted and registered in the DNPR (even when no resuscitation is attempted at the hospital). Data linkage to the Danish Register of Causes of Death ${ }^{198}$ may help to provide a more complete picture of the incidence of acute fatal events not included in the DNPR. ${ }^{170}$

Third, it may be difficult - or even impossible - to identify incident diagnoses of chronic diseases in older patients because of immigration or the lack of hospital data before 1977. Thus, events occurring prior to 1977 are left censored if individuals are enrolled in a study and left truncated if they are not. ${ }^{214}$ On the other hand, the DNPR enables reconstruction of individual life and health trajectories of persons born in 1977 or later.

Fourth, defining incidence by "the first occurrence of the disease in the registry" leads to overestimation of incidence in the period immediately following the initiation of the DNPR, after initiation of a screening program, or after introduction of new registry codes, due to misclassification of "backlogged" prevalent cases as incident cases. Because this problem decreases with the passage of time after 1977 or with the number of screening rounds, a "washout period" before identification of incident cases may reduce the error. This source of error is less important when examining diseases of short duration, such as infections. The transition from ICD-8 to ICD-10 in 1994 and inclusion of outpatients and ED diagnoses in 1995 may similarly introduce artifacts in long-term incidence trends. Exemplifying this problem, the incidence of alcoholic cirrhosis showed no clear trend for men or women of any age from 1988 to 1993 but apparently increased by $32 \%$ in 1994 and by an additional 10\% when including outpatient and ED visits. ${ }^{122}$

Fifth, changes in classification systems and diagnostic criteria and use of more sensitive diagnostic methods over time (diagnostic drift) may hamper the interpretation of secular trends in incidence. As an example, a transient increase in the observed rate of hospitalization with myocardial infarction in Denmark between 2000 and 2004 was likely attributable not to the true increase of occurrence but to new diagnostic criteria introduced in 2000, which included troponin as the main diagnostic biomarker. ${ }^{170,215}$ Similar time-trend biases have been observed for the incidence of primary liver cancer ${ }^{203}$ and advanced stages of lung cancer, the latter leading to an apparent improvement over time in stage-specific prognosis. ${ }^{216}$

\section{Data access}

The Danish Health and Medicines Authority has established guidelines for releasing data from the DNPR. Implementing the European Union Data Protection Directive (Directive $95 / 46 / E C)$ on the protection of individuals with regard to the processing of personal data and on the free movement of such data, the Danish Act on Processing of Personal Data provides the legal basis for private and public institutions to obtain individually identifiable health data for research purposes. ${ }^{217}$ This Act protects against abuse of such data and thus balances the privacy rights of individuals and the society's need for quality research. In order to access data from the DNPR, researchers have to apply to Research Service (Danish, Forskerservice). ${ }^{26,218}$ Use of any health data also requires project-specific permission from the Danish Data Protection Agency, ${ }^{217}$ and, in many cases, additional permission from the Danish Health and Medicines Authority to link data from various registries. ${ }^{26}$ The Danish Data Protection Agency specifies safety precautions for data processing and also sets cancellation deadlines, ensuring that data traceable to individuals will not be stored longer than required to complete a project. As well, it is necessary to obtain permission from the Danish Health and Medicines Authority and the chief physician from relevant hospital departments to retrieve medical record files for validation of DNPR data. ${ }^{219}$

\section{Conclusion}

The DNPR is a valuable tool for epidemiological research, providing longitudinal registration of diagnoses, treatments, and examinations, with complete nationwide coverage since 1978. Denmark's constellation of universal health care, routine and long-standing registration of life and health events, and the possibility of exact individual-level linkage impart virtually unlimited research possibilities onto the DNPR. At the same time, varying completeness and validity of the individual variables underscore the need for validation of its clinical data before using the registry for research. 


\section{Acknowledgments}

The study was approved by the Danish Data Protection Agency (record number 1-16-02-1-08). Author HTS was supported by the Program for Clinical Research Infrastructure (PROCRIN) established by the Lundbeck Foundation and the Novo Nordisk Foundation, and the Department of Clinical Epidemiology's Research Foundation. The funding sources had no role in the design, conduct, analysis, or reporting of the study.

\section{Author contributions}

MS conceived the study idea, designed the study, and wrote the initial draft. MS reviewed the literature on the registry content together with JLS; study examples together with HTS; and previous validation studies together with SAJS. HTS obtained data permissions and LP collected the data and carried out the descriptive analyses. All authors contributed to data analysis, drafting and critical revision of the paper, and agree to be accountable for all aspects of the work.

\section{Disclosure}

The authors report no conflicts of interest in this work.

\section{References}

1. Sørensen HT. Regional administrative health registries as a resource in clinical epidemiology: a study of options, strengths, limitations and data quality provided with examples of use. Int J Risk Saf Med. 1997;10(1): $1-22$.

2. Sorensen HT, Sabroe S, Olsen J. A framework for evaluation of secondary data sources for epidemiological research. Int J Epidemiol. 1996;25(2): 435-442.

3. Benchimol EI, Smeeth L, Guttmann A, et al. The Reporting of studies Conducted using Observational Routinely-collected health Data (RECORD) Statement. PLoS Med. 2015;12(10):e1001885.

4. PHARMO. The Dutch Hospital Database. Available from: http://www. pharmo.nl/pharmo-databases/hospitalisations-lmr. Accessed April 1, 2015.

5. García-Rodríguez LA, Pérez Gutthann S. Use of the UK general practice research database for pharmacoepidemiology. Br J Clin Pharmacol. 1998;45(5):419-425.

6. Lichtman JH, Leifheit-Limson EC, Goldstein LB. Centers for medicare and medicaid services medicare data and stroke research: goldmine or landmine? Stroke. 2015;46(2):598-604.

7. Boyko EJ, Koepsell TD, Gaziano JM, Horner RD, Feussner JR. US department of veterans affairs medical care system as a resource to epidemiologists. Am J Epidemiol. 2000;151(3):307-314.

8. Herrett E, Gallagher AM, Bhaskaran K, et al. Data resource profile: clinical practice research datalink (CPRD). Int J Epidemiol. 2015;44(3): 827-836.

9. National Cancer Institute. Pharmacoepidemiology and Healthcare Databases. Available from: http://epi.grants.cancer.gov/pharm/ pharmacoepi_db/. Accessed June 24, 2015.

10. Health Statistics for the Nordic Countries 2014. Nordic MedicoStatistical Committee; 2014:102.

11. Olsen J, Basso O, Sørensen HT. What is a population-based registry? Scand J Public Health. 1999;27(1):78-78.

12. Sund R. Quality of the Finnish hospital discharge register: a systematic review. Scand J Public Health. 2012;40(6):505-515.
13. Ludvigsson JF, Andersson E, Ekbom A, et al. External review and validation of the Swedish national inpatient register. BMC Public Health. 2011;11(1):450.

14. Gudbjornsson B, Thorsteinsson SB, Sigvaldason H, et al. Rofecoxib, but not celecoxib, increases the risk of thromboembolic cardiovascular events in young adults - a nationwide registry-based study. Eur J Clin Pharmacol. 2010;66(6):619-625.

15. Helsedirektoratet. [Norsk pasientregister]. Available from: http://www. helsedirektoratet.no/kvalitet-planlegging/norsk-pasientregister-npr/ innhold-og-kvalitet/Sider/default.aspx. Accessed April 1, 2015.

16. Office of the Auditor General of Norway. [Revisjonsrapport om $k$ valiteten på de medisinske kodingene i helseforetakene som grunnlag for innsatsstyrt finansiering. I: Riksrevisjonens kontroll med forvaltningen av statlige selskaper for 2008]. Dokument 3: 2 (2009-2010), Vedlegg 5; Oslo:2009.

17. Lynge E, Sandegaard JL, Rebolj M. The Danish national patient register. Scand J Public Health. 2011;39(7 Suppl):30-33.

18. Andersen TF, Madsen M, Jorgensen J, Mellemkjoer L, Olsen JH. The Danish national hospital register. A valuable source of data for modern health sciences. Dan Med Bull. 1999;46(3):263-268.

19. Nickelsen TN. Data validity and coverage in the Danish National Health Registry. A literature review [in Danish: Datavaliditet og dækningsgrad i Landspatientregisteret. En litteraturgennemgang]. Ugeskr Laeger. 2002;164(1):33-37.

20. Schmidt M, Pedersen L, Sørensen HT. The Danish civil registration system as a tool in epidemiology. Eur J Epidemiol. 2014;29(8): 541-549.

21. Ministry of Interior and Health. Health Care in Denmark; 2008. Available from: http://tyskland.um.dk/de/ /media/Tyskland/German-site/ Documents/Reise\%20und\%20Aufenthalt/Health\%20Care\%20in\%20 Denmark.pdf. Accessed October 8, 2015.

22. Frank L. Epidemiology. When an entire country is a cohort. Science. 2000;287(5462):2398-2399.

23. Danish Health and Medicines Authority. The Danish National Patient Registry Through 25 Years: 1977-2002; 2003. Copenhagen [Report no 21].

24. Danish Health and Medicines Authority. [Evaluation of the Danish National Patient Registry 1990]. Hospital Statistics II: 57; Copenhagen: 1993.

25. Madsen KM, Schønheyder HC, Kristensen B, Nielsen GL, Sørensen HT. Can hospital discharge diagnosis be used for surveillance of bacteremia? A data quality study of a Danish hospital discharge registry. Infect Control Hosp Epidemiol. 1998;19(3):175-180.

26. eSundhed. Documentation of the Danish National Patient Registry. Available from: http://www.esundhed.dk/dokumentation/Registre/ Sider/Register.aspx\#Pc980378f70f74dd890a9bdb3d00abd5a_2_340i T0. Accessed April 1, 2015.

27. Department of Clinical Epidemiology, Aarhus University Hospital, Denmark. AUDEO - Program for Disease Epidemiology and Outcomes. Available from: http://www.audeo.dk/sygdomsmonitorering. aspx. Accessed April 1, 2015.

28. Lidegaard $\varnothing$, Vestergaard $\mathrm{CH}$, Hammerum MS. Quality monitoring based on data from the Danish National Patient Registry. [in Danish: Kvalitetsmonitorering ud fra data i Landspatientregisteret]. Ugeskr Laeger. 2009;171(6):412-415.

29. The Diagnosis Related Group (DRG) System. [Beretning om DRGSystemet]. The National Audit Office of Denmark. Copenhagen: 2011. [in Danish].

30. The Diagnosis Related Group (DRG) system and the Danish Ambulant Grouping System (DAGS). Available from: http://www.drg.dk. Accessed April 1, 2015

31. Mors O, Perto GP, Mortensen PB. The Danish psychiatric central research register. Scand J Public Health. 2011;39(7 Suppl):54-57.

32. Krebs L, Johansen AMT, Helweg-Larsen K. Indberetning af prokerede aborter i 1994: En sammenligning mellem data i registret over Legalt Provokerede Aborter og Landspatientregistret. Ugeskr Laeger. 1997; 159(11):1607-1611. 
33. Knudsen L, Olsen J. The Danish medical birth registry. Dan Med Bull. 1998;45(3):320-323.

34. Gjerstorff ML. The Danish cancer registry. Scand J Public Health. 2011;39(7 Suppl):42-45.

35. Danish Health and Medicines Authority. Changes in the reporting to the Danish National Patient Registry, 2000-2015 [in Danish: Endringer til indberetning til Landspatientregisteret]; 2015.

36. Danish Health and Medicines Authority. Fællesindhold for basisregistrering af sygehuspatienter - Vejledningsdel [Common Content for Basic Registration of Hospital Patients 2014 - Instruction Part] 22nd ed; 2014. Copenhagen [Report no 6]. Danish.

37. Danish Health and Medicines Authority. Common Content for Basic Registration of Hospital Patients 2014 - Technical Part (in Danish: Fallesindhold for basisregistrering af sygehuspatienter-Teknisk del). 23nd ed; 2013. Copenhagen [Report no 6].

38. Danish Health and Medicines Authority. Bekendtgørelse om logers anmeldelse til Sundhedsstyrelsens Landspatientregister af patienter behandlet på private sygehuse eller klinikker; 2003. Copenhagen [Notification no 986].

39. Danish Health and Medicines Authority. Bekendtgørelse om lægers anmeldelse til Sundhedsstyrelsens Landspatientregister af patienter behandlet på private sygehuse eller klinikker; 2007. Copenhagen [Notification no 1073].

40. Danish Health and Medicines Authority. Private hospital activity 2006-2010 [In Danish: Aktivitet på private sygehuse 2006-2010]; 2011. Available from: http://sundhedsstyrelsen.dk/publ/Publ2011/ DOKS/AktivitetPrivateSygehuse/AktvitetPrivateSygehuse2006-10. pdf. Accessed April 1, 2015.

41. Politiken. Lack of control with private hospitals. [in Danish: Hul $i$ kontrollen med privathospitaler]; 2008. Available from: http://pol. dk/565165. Accessed August 1, 2015.

42. Personal Correspondence. Sundhedsdokumentation Sektor for National Sundhedsdokumentation og Forskning, Denmark. 2014:1-2.

43. National Health IT. Sundhedsvaesenets Klassifikations System $(S K S)$. Available from: http://www.ssi.dk/sks. Accessed October 1, 2015.

44. National Health IT. SKS-Browser. Available from: http://www.medinfo. dk/sks/brows.php. Accessed April 1, 2015.

45. The reference as indicated is correct (free access as guest user), thus with the updated date the please change the reference to: National Health IT. Historical SKS Codes. Available from: ftp://filer.sst.dk/filer/sks/data/ skscomplete/. Accessed October 1, 2015.

46. Centers for Disease Control and Prevention. International Classification of Diseases, Tenth Revision, Clinical Modification (ICD-10-CM). Available from: http://www.cdc.gov/nchs/icd/icd10 cm.htm. Accessed April 1, 2015.

47. Danish Health and Medicines Authority. Danish Classification of Surgical Procedures and Therapies. 1st, 2nd, 3rd ed. Copenhagen, Denmark: Danish Health and Medicines Authority; 1973, 1980, 1988.

48. The Nordic Medico-Statistical Committee (NOMESCO) Classification of Surgical Procedures. Available from: http://nowbase.org/ Publikationer/ /media/Projekt\%20sites/Nowbase/Publikationer/NCSP/ NCSP\%201_14.ashx. Accessed April 1, 2015.

49. Baron JA, Sørensen HT, Sox Jr HC. Clinical epidemiology. In: Olsen J, Saracci R, Trichopoulos D, editors. Teaching Epidemiology: A Guide for Teachers in Epidemiology, Public Health and Clinical Medicine. 4th ed., pp. 444-462. Oxford: Oxford University Press; 2015.

50. Jürgensen HJ, Frølund C, Gustafsen J, Mosbech H, Guldhammer B, Mosbech J. Registration of diagnoses in the Danish national registry of patients. Methods Inf Med. 1986;25(3):158-164.

51. Division of Health Planning at C. F. Møller on behalf of The Danish National Board of Health. Project concerning data quality in The Danish National Patient Registry [in Danish: Projekt vedrørende datakvalitet i Landspatientregistret]. 2004.

52. Vest-Hansen B, Riis AH, Christiansen CF. Registration of acute medical hospital admissions in the Danish national patient registry: a validation study. Clin Epidemiol. 2013;5:129-133.
53. Holland-Bill L, Xu H, Sørensen HT, et al. Positive predictive value of primary inpatient discharge diagnoses of infection among cancer patients in the Danish national registry of patients. Ann Epidemiol. 2014;24(8):593-7, 597. e1-e18.

54. Sørensen HT, Hansen I, Ejlersen E, Schønheyder HC, Hamburger H, Sabroe S. Identification of cases of meningococcal disease: data quality in two Danish population-based information systems during a 14-year period. Int J Risk Saf Med. 1995;7(3):179-189.

55. Gradel KO, Nielsen SL, Pedersen C, et al; Danish Collaborative Bacteraemia Network (DACOBAN), Danish Observational Registry of Infectious Syndromes (DORIS). Low completeness of bacteraemia registration in the Danish national patient registry. PLoS One. 2015;10(6):e0131682.

56. Søgaard KK, Thomsen RW, Schønheyder HC, Søgaard M. Positive predictive values of the international classification of diseases, 10th revision diagnoses of Gram-negative septicemia/sepsis and urosepsis for presence of Gram-negative bacteremia. Clin Epidemiol. 2015;7:195-199.

57. Obel N, Reinholdt H, Omland LH, Engsig F, Sørensen HT, Hansen A-BE. Retrivability in the Danish national hospital registry of HIV and hepatitis $\mathrm{B}$ and $\mathrm{C}$ coinfection diagnoses of patients managed in HIV centers 1995-2004. BMC Med Res Methodol. 2008;8:25.

58. Thygesen SK, Christiansen CF, Christensen S, Lash TL, Sørensen HT. The predictive value of ICD-10 diagnostic coding used to assess Charlson comorbidity index conditions in the population-based Danish national registry of patients. BMC Med Res Methodol. 2011;11:83.

59. Osterlind A, Jensen OM. Evaluation of cancer registration in Denmark in 1977. Preliminary evaluation of cancer registration by the Cancer Register and the National Patient Register [in Danish: Evaluering af cancerregistreringen i Danmark 1977. En praeliminaer evaluering af cancerregisterets og landspatientregisterets registrering af cancertilfaelde]. Ugeskr Laeger. 1985;147(31): 2483-2488.

60. Helqvist L, Erichsen R, Gammelager H, Johansen MB, Sørensen HT. Quality of ICD-10 colorectal cancer diagnosis codes in the Danish national registry of patients. Eur J Cancer Care (Engl). 2012;21(6): $722-727$.

61. Lash TL, Riis AH, Ostenfeld EB, Erichsen R, Vyberg M, ThorlaciusUssing $\mathrm{O}$. A validated algorithm to ascertain colorectal cancer recurrence using registry resources in Denmark. Int J Cancer. 2015;136(9): 2210-2215.

62. Kjaergaard J, Clemmensen IH, Storm HH. Validity and completeness of registration of surgically treated malignant gynaecological diseases in the Danish national hospital registry. $J$ Epidemiol Biostat. 2001;6(5):387-392.

63. Drljevic A, Borre M, Ehrenstein V, Nguyen-nielsen M, Høyer M. Quality of venous thromboembolism diagnoses among prostate cancer patients in the Danish national registry of patients. Clin Epidemiol. 2014;6:351-357.

64. Gammelager H, Christiansen CF, Johansen MB, Borre M, Schoonen M, Sørensen HT. Quality of urological cancer diagnoses in the Danish national registry of patients. Eur J Cancer Prev. 2012;21(6): 545-551.

65. Jensen AØ, Nørgaard M, Yong M, Fryzek JP, Sørensen HT. Validity of the recorded international classification of diseases, 10th edition diagnoses codes of bone metastases and skeletal-related events in breast and prostate cancer patients in the Danish national registry of patients. Clin Epidemiol. 2009;1:101-108.

66. Ehrenstein V, Hernandez RK, Maegbaek ML, et al. Validation of algorithms to detect distant metastases in men with prostate cancer using routine registry data in Denmark. Clin Epidemiol. 2015;7:259-265.

67. Nørgaard M, Skriver MV, Gregersen H, Pedersen G, Schønheyder HC, Sørensen HT. The data quality of haematological malignancy ICD-10 diagnoses in a population-based hospital discharge registry. Eur $J$ Cancer Prev. 2005;14(3):201-206.

68. Kjaergaard J, Clemmensen IH, Thomsen BL, Storm HH. Validity of diagnoses of and operations for nonmalignant gynecological conditions in the Danish national hospital registry. J Clin Epidemiol. 2002;55(2): $137-142$. 
69. Nielsen EH, Lindholm J, Laurberg P. Use of combined search criteria improved validity of rare disease (craniopharyngioma) diagnosis in a national registry. J Clin Epidemiol. 2011;64(10):1118-1126.

70. Gregersen H, Larsen C, Haglund A, Mortensen R, Andersen NF, Nørgaard M. Data quality of the monoclonal gammopathy of undetermined significance diagnosis in a hospital registry. Clin Epidemiol. 2013;5:321-326.

71. Andersen GS, Toftdahl D, Nielsen PE, Strandgaard S, Lund JO. Pheochromocytoma in Denmark 1977-1981 [in Danish: Faeokromocytom i Danmark 1977-1981]. Ugeskr Laeger. 1986;148(47):3109-3113.

72. Zalfani J, Frøslev T, Olsen M, et al. Positive predictive value of the international classification of diseases, 10th edition diagnosis codes for anemia caused by bleeding in the Danish national registry of patients. Clin Epidemiol. 2012;4:327-331.

73. Ben Ghezala I, Arendt JF, Erichsen R, et al. Positive predictive value of the diagnosis coding for vitamin B12 deficiency anemia in the Danish national patient register. Clin Epidemiol. 2012;4:333-338.

74. Heden KEK, Jensen AØ, Farkas DK, Nørgaard M. Validity of a procedure to identify patients with chronic idiopathic thrombocytopenic purpura in the Danish national registry of patients. Clin Epidemiol. 2009;1:7-10.

75. Kristensen JK, Drivsholm TB, Carstensen B, Steding-Jensen M, Green A. Validation of methods to identify known diabetes on the basis of health registers [in Danish: Validering af metoder til identifikation af erkendt diabetes på basis af administrative sundhedsregistre]. Ugeskr Laeger. 2007;169(18):1687-1692.

76. Thomsen RW, Hundborg HH, Lervang H-H, Johnsen SP, Sørensen HT, Schønheyder HC. Diabetes and outcome of community-acquired pneumococcal bacteremia: a 10 -year population-based cohort study. Diabetes Care. 2004;27(1):70-76.

77. Atladóttir HO, Pedersen MG, Thorsen P, et al. Association of family history of autoimmune diseases and autism spectrum disorders. Pediatrics. 2009;124(2):687-694.

78. Svensson J, Marinelli K, Eising S. Landspatientregisteret over for et specialespecifikt register for diabetes i barnealderen? Ugeskr Laeger. 2007;169(2):122.

79. Nielsen GL, Sørensen HT, Pedersen AB, Sabroe S. Analyses of data quality in registries concerning diabetes mellitus - A comparison between a population based hospital discharge and an insulin prescription registry. J Med Syst. 1996;20(1):1-10.

80. Dal J, Skou N, Nielsen EH, Pedersen L, Joergensen JOL. Acromegaly according to the Danish national registry of patients: how valid are ICD diagnoses and how do patterns of registration affect the accuracy of registry data? Clin Epidemiol. 2014;6:295-299.

81. Lund JO, Andersen GS, Toftdahl D, Strandgaard S, Nielsen PE. Primary aldosteronism (Conn's syndrome) in Denmark 1977-1981 [in Danish: Primaer aldosteronisme (Conn's syndrom) i Danmark 1977-1981]. Ugeskr Laeger. 1986;148(47):3115-3118.

82. Rasmussen NH, Thomsen RW, Rasmussen HH, Søgaard M. Validity of diagnostic coding for undernutrition in hospitals. Clin Nutr. 2015. Epub ahead of print.

83. Holland-Bill L, Christiansen CF, Ulrichsen SP, Ring T, Jørgensen JOL, Sørensen HT. Validity of the international classification of diseases, 10th revision discharge diagnosis codes for hyponatraemia in the Danish national registry of patients. BMJ Open. 2014;4(4):e004956.

84. Phung TKT, Andersen BB, Høgh P, Kessing LV, Mortensen PB, Waldemar G. Validity of dementia diagnoses in the Danish hospital registers. Dement Geriatr Cogn Disord. 2007;24(3):220-228.

85. Kioumourtzoglou M-A, Seals RM, Himmerslev L, Gredal O, Hansen J, Weisskopf MG. Comparison of diagnoses of amyotrophic lateral sclerosis by use of death certificates and hospital discharge data in the Danish population. Amyotroph Lateral Scler Frontotemporal Degener. 2015;16(3-4):224-229.

86. Wermuth L, Lassen CF, Himmerslev L, Olsen J, Ritz B. Validation of hospital register-based diagnosis of Parkinson's disease. Dan Med J. 2012;59(3):A4391.
87. Rugbjerg K, Ritz B, Korbo L, Martinussen N, Olsen JH. Risk of Parkinson's disease after hospital contact for head injury: population based case-control study. BMJ. 2008;337:a2494.

88. Greene N, Lassen CF, Rugbjerg K, Ritz B. Reproductive factors and Parkinson's disease risk in Danish women. Eur J Neurol. 2014;21(9): 1168-e68.

89. Mason K, Thygesen LC, Stenager E, Brønnum-Hansen H, KochHenriksen N. Evaluating the use and limitations of the Danish national patient register in register-based research using an example of multiple sclerosis. Acta Neurol Scand. 2012;125(3):213-217.

90. Christensen J, Vestergaard M, Olsen J, Sidenius P. Validation of epilepsy diagnoses in the Danish national hospital register. Epilepsy Res. 2007;75(2-3):162-170.

91. Krarup L-H, Boysen G, Janjua H, Prescott E, Truelsen T. Validity of stroke diagnoses in a National register of patients. Neuroepidemiology. 2007;28(3):150-154.

92. Johnsen SP, Overvad K, Sørensen HT, Tjønneland A, Husted SE. Predictive value of stroke and transient ischemic attack discharge diagnoses in the Danish national registry of patients. J Clin Epidemiol. 2002;55(6):602-607.

93. Djurhuus BD, Skytthe A, Faber CE. Validation of the cholesteatoma diagnosis in the Danish national hospital register. Dan Med Bull. 2010;57(10):A4159.

94. Schmidt M, Johannesdottir SA, Lemeshow S, et al. Obesity in young men, and individual and combined risks of type 2 diabetes, cardiovascular morbidity and death before 55 years of age: a Danish 33-year follow-up study. BMJ Open. 2013;3(4):e002698.

95. Nielsen HW, Tüchsen F, Jensen MV. Validiteten af diagnosen essentiel hypertension i Landspatientregistret. Ugeskr Laeger. 1996;158(2): 163-167.

96. Joensen AM, Jensen MK, Overvad K, et al. Predictive values of acute coronary syndrome discharge diagnoses differed in the Danish national patient registry. J Clin Epidemiol. 2009;62(2):188-194.

97. Coloma PM, Valkhoff VE, Mazzaglia G, et al; EU-ADR Consortium. Identification of acute myocardial infarction from electronic healthcare records using different disease coding systems: a validation study in three European countries. BMJ Open. 2013;3(6):e002862.

98. Stratifed analyses of the positive predictive values were kindly provided by Albert Marni Joensen, Department of Cardiology, Aalborg University Hospital, Aalborg, Denmark; 2014.

99. Madsen M, Davidsen M, Rasmussen S, Abildstrom SZ, Osler M. The validity of the diagnosis of acute myocardial infarction in routine statistics: a comparison of mortality and hospital discharge data with the Danish MONICA registry. J Clin Epidemiol. 2003;56(2):124-130.

100. Madsen M, Balling H, Eriksen LS. The validity of the diagnosis of acute myocardial infarction in two registries: the Heart Registry compared to the National Patient Registry [in Danish: Validiteten af diagnosen akut myokardieinfarkt $\mathrm{i}$ to registre: Hjerteregistret sammenlignet med Landspatientregistret]. Ugeskr Laeger. 1990;152(5): 308-314.

101. Severinsen MT, Kristensen SR, Overvad K, Dethlefsen C, Tjønneland A, Johnsen SP. Venous thromboembolism discharge diagnoses in the Danish national patient registry should be used with caution. J Clin Epidemiol. 2010;63(2):223-228.

102. Larsen TB, Johnsen SP, Møller CI, Larsen H, Sørensen HT. A review of medical records and discharge summary data found moderate to high predictive values of discharge diagnoses of venous thromboembolism during pregnancy and postpartum. J Clin Epidemiol. 2005;58(3): 316-319.

103. Ingeman A, Andersen G, Hundborg HH, Johnsen SP. Medical complications in patients with stroke: data validity in a stroke registry and a hospital discharge registry. Clin Epidemiol. 2010;2:5-13.

104. Rix TA, Riahi S, Overvad K, Lundbye-Christensen S, Schmidt EB, Joensen AM. Validity of the diagnoses atrial fibrillation and atrial flutter in a Danish patient registry. Scand Cardiovasc J. 2012;46(3): 149-153. 
105. Frost L, Andersen LV, Vestergaard P, Husted S, Mortensen LS. Trend in mortality after stroke with atrial fibrillation. Am J Med. 2007;120(1): $47-53$.

106. Frost L, Vestergaard P. Alcohol and risk of atrial fibrillation or flutter: a cohort study. Arch Intern Med. 2004;164(18):1993-1998.

107. Mard S, Nielsen FE. Positive predictive value and impact of misdiagnosis of a heart failure diagnosis in administrative registers among patients admitted to a university hospital cardiac care unit. Clin Epidemiol. 2010;2:235-239.

108. Kümler T, Gislason GH, Kirk V, et al. Accuracy of a heart failure diagnosis in administrative registers. Eur J Heart Fail. 2008;10(7): 658-660.

109. Wildenschild C, Mehnert F, Thomsen RW, et al. Registration of acute stroke: validity in the Danish stroke registry and the Danish national registry of patients. Clin Epidemiol. 2013;6:27-36.

110. Gaist D, Vaeth M, Tsiropoulos I, et al. Risk of subarachnoid haemorrhage in first degree relatives of patients with subarachnoid haemorrhage: follow up study based on national registries in Denmark. BMJ. 2000;320(7228):141-145.

111. Tuckuviene R, Kristensen SR, Helgestad J, Christensen AL, Johnsen SP. Predictive value of pediatric thrombosis diagnoses in the Danish national patient registry. Clin Epidemiol. 2010;2:107-122.

112. Schmidt M, Cannegieter SC, Johannesdottir SA, Dekkers OM, Horvath-Puho E, Sørensen HT. Statin use and venous thromboembolism recurrence: a combined nationwide cohort and nested case-control study. J Thromb Haemost. 2014;12(8):1207-1215.

113. Lidegaard Ø, Nielsen LH, Skovlund CW, Skjeldestad FE, Løkkegaard E. Risk of venous thromboembolism from use of oral contraceptives containing different progestogens and oestrogen doses: Danish cohort study, 2001-9. BMJ. 2011;343:d6423-d6423.

114. Stensballe LG, Kristensen K, Nielsen J, Aaby P. Diagnosis coding in the Danish national patient registry for respiratory syncytial virus infections. Scand J Infect Dis. 2005;37(10):747-752.

115. Thomsen RW, Lange P, Hellquist B, et al. Validity and underrecording of diagnosis of COPD in the Danish national patient registry. Respir Med. 2011;105(7):1063-1068.

116. Jensen AØ, Nielsen GL, Ehrenstein V. Validity of asthma diagnoses in the Danish national registry of patients, including an assessment of impact of misclassification on risk estimates in an actual dataset. Clin Epidemiol. 2010;2:67-72.

117. Moth G, Vedsted P, Schiøtz PO. National registry diagnoses agree with medical records on hospitalized asthmatic children. Acta Paediatr. 2007;96(10):1470-1473.

118. Søgaard M, Kornum JB, Schønheyder HC, Thomsen RW. Positive predictive value of the ICD-10 hospital diagnosis of pleural empyema in the Danish national registry of patients. Clin Epidemiol. 2011;3: 85-89.

119. Lassen A, Hallas J, de Muckadell OBS. Complicated and uncomplicated peptic ulcers in a Danish county 1993-2002: a population-based cohort study. Am J Gastroenterol. 2006;101(5):945-953.

120. Fonager K, Sørensen HT, Rasmussen SN, Møller-Petersen J, Vyberg M. Assessment of the diagnoses of Crohn's disease and ulcerative colitis in a Danish hospital information system. Scand J Gastroenterol. 1996;31(2):154-159.

121. Vestberg K, Thulstrup AM, Sørensen HT, Ottesen P, Sabroe S, Vilstrup H. Data quality of administratively collected hospital discharge data for liver cirrhosis epidemiology. J Med Syst. 1997;21(1):11-20.

122. Jepsen P, Vilstrup H, Sørensen HT. Alcoholic cirrhosis in Denmark population-based incidence, prevalence, and hospitalization rates between 1988 and 2005: a descriptive cohort study. BMC Gastroenterol. 2008;8(1):3.

123. Erichsen R, Strate L, Sørensen HT, Baron JA. Positive predictive values of the international classification of disease, 10th edition diagnoses codes for diverticular disease in the Danish national registry of patients. Clin Exp Gastroenterol. 2010;3:139-142.
124. Floyd A, Pedersen L, Nielsen GL, Thorladcius-Ussing O, Sørensen HT. Secular trends in incidence and 30-day case fatality of acute pancreatitis in North Jutland County, Denmark: a register-based study from 1981-2000. Scand J Gastroenterol. 2002;37(12): 1461-1465.

125. Majholm B, Bartholdy J, Christoffersen JK, Engbæk J, Møller AM. Poor agreement between data from the National patient registry and the Danish patient insurance association. Dan Med J. 2012;59(6):A4430.

126. Pedersen M, Klarlund M, Jacobsen S, Svendsen AJ, Frisch M. Validity of rheumatoid arthritis diagnoses in the Danish national patient registry. Eur J Epidemiol. 2004;19(12):1097-1103.

127. Friis S, Mellemkjaer L, McLaughlin JK, et al. Connective tissue disease and other rheumatic conditions following breast implants in Denmark. Ann Plast Surg. 1997;39(1):1-8.

128. Jensen MV, Tüchsen F. Erhverv og diskusprolaps i lænden [Lumbar disc prolapse]. Ugeskr Laeger. 1995;157(11):1519-1523. Danish.

129. Gammelager H, Sværke C, Noerholt SE, et al. Validity of an algorithm to identify osteonecrosis of the jaw in women with postmenopausal osteoporosis in the Danish national registry of patients. Clin Epidemiol. 2013;5:263-267.

130. Gammelager H, Erichsen R, Antonsen S, et al. Positive predictive value of the international classification of diseases, 10th revision, codes to identify osteonecrosis of the jaw in patients with cancer. Cancer Epidemiol. 2012;36(4):381-383.

131. Ehrenstein V, Gammelager H, Schiødt M, et al. Evaluation of an ICD-10 algorithm to detect osteonecrosis of the jaw among cancer patients in the Danish national registry of patients. Pharmacoepidemiol Drug Saf. 2015;24(7):693-700.

132. Schmidt L, Damsgaard MT, Nielsen JM. An evaluation of the national patient register. A study of validity of some abortion diagnoses. Ugeskr Laeger. 1989;151(51):3478-3482.

133. Lohse SR, Farkas DK, Lohse N, et al. Validation of spontaneous abortion diagnoses in the Danish national registry of patients. Clin Epidemiol. 2010;2:247-250.

134. Klemmensen ÅK, Olsen SF, Østerdal ML, Tabor A. Validity of preeclampsia-related diagnoses recorded in a national hospital registry and in a postpartum interview of the women. Am J Epidemiol. 2007; 166(2):117-124.

135. Kristensen J, Langhoff-Roos J, Skovgaard LT, Kristensen FB Validation of the Danish birth registration. J Clin Epidemiol. 1996; 49(8):893-897.

136. Langhoff-Roos J, Rasmussen S. Danish Health and Medicines Authority. [Validering af Landspatientregistret (LPR) mhp. obstetrisk forskning og kvalitetssikring]; Copenhagen: 2003.

137. Devantier A, Kjer JJ. The national patient register - a research tool? [in Danish: Landspatientregistret - et forskningsredskab?]. Ugeskr Laeger. 1991;153(7):516-517.

138. Thygesen SK, Olsen M, Christiansen C. Positive predictive value of the infant respiratory distress syndrome diagnosis in the Danish national patient registry. Clin Epidemiol. 2013;5:295-298.

139. Maimburg RD, Bech BH, Bjerre JV, Olsen J, Møller-Madsen B. Obstetric outcome in Danish children with a validated diagnosis of kernicterus. Acta Obstet Gynecol Scand. 2009;88(9):1011-1016.

140. Agergaard P, Hebert A, Bjerre J, Sørensen KM, Olesen C, Ostergaard JR. Children diagnosed with congenital cardiac malformations at the national university departments of pediatric cardiology: positive predictive values of data in the Danish national patient registry. Clin Epidemiol. 2011;3:61-66.

141. Jepsen B, Jepsen P, Johnsen SP, Espersen GT, Sørensen HT. Validity of diagnoses of cardiac malformations in a Danish populationbased hospital-discharge registry. Int J Risk Saf Med. 2006;18(2): $77-81$.

142. Larsen H, Nielsen GL, Bendsen J, Flint C, Olsen J, Sørensen HT. Predictive value and completeness of the registration of congenital abnormalities in three Danish population-based registries. Scand $J$ Public Health. 2003;31(1):12-16. 
143. Jensen MS, Snerum TM, Olsen LH, et al. Accuracy of cryptorchidism diagnoses and corrective surgical treatment registration in the Danish national patient registry. $J$ Urol. 2012;188(4):1324-1329.

144. Pedersen L, Skriver MV, Nørgaard M, Sørensen HT. Maternal use of loratadine during pregnancy and risk of hypospadias in offspring. Int J Med Sci. 2006;3(1):21-25.

145. Gravholt CH, Juul S, Naeraa RW, Hansen J. Morbidity in Turner syndrome. J Clin Epidemiol. 1998;51(2):147-158.

146. Vestergaard M, Obel C, Henriksen TB. The Danish national hospital register is a valuable study base for epidemiologic research in febrile seizures. J Clin Epidemiol. 2006;59(1):61-66.

147. Lauridsen MD, Gammelager H, Schmidt M, Nielsen H, Christiansen CF. Positive predictive value of international classification of diseases, 10(th) revision, diagnosis codes for cardiogenic, hypovolemic, and septic shock in the Danish national patient registry. BMC Med Res Methodol. 2015;15(1):23.

148. Sørensen HT, Nielsen JO, Nissen I, Nielsen J. Head injuries. I. An epidemiological study based on 596 patients over a 4-year period [in Danish: Kranietraumer. I. En epidemiologisk undersøgelse baseret på 596 patienter i en 4 års periode]. Ugeskr Laeger. 1987;149(10):680-683.

149. Hougaard K, Kjaersgaard-Andersen P, Kuur E. Registration under the diagnosis of traumatic hip luxation in the national registry [in Danish: Landspatientregisterets registrering under diagnosen traumatisk hofteluksation]. Ugeskr Laeger. 1992;154(40):2747-2748.

150. Sørensen HT, Nielsen B, Ostergaard Nielsen J. Anaphylactic shock occurring outside hospitals. Allergy. 1989;44(4):288-290.

151. Lange J, Pedersen AB, Troelsen A. Do hip prosthesis related infection codes in administrative discharge registers correctly classify periprosthetic hip joint infection? Hip Int. 2015. Epub ahead of print.

152. McLaughlin JK, Olsen JH, Friis S, Mellemkjaer L, Fraumeni JF. Re: breast implants, cancer, and systemic sclerosis. J Natl Cancer Inst. 1995;87(18):1415-1416.

153. Holte K, Bay-Nielsen M, Utzon J, Støckel M, Funch-Jensen P, Kehlet H. Operation for gastroøsofageal refluks i Danmark 1997-1999. Ugeskr Laeger. 2001;163(41):5658-5661.

154. Harboe KM, Anthonsen K, Bardram L. Validation of data and indicators in the Danish cholecystectomy database. Int J Qual Health Care. 2009;21(3):160-168.

155. Jespersen CG, Borre M, Nørgaard M. Validity of the recorded codes of gonadotropin-releasing hormone agonist treatment and orchiectomies in the Danish national patient registry. Clin Epidemiol. 2012;4: 145-149.

156. Møller C, Kehlet H, Utzon J, Ottesen BS. Hysterectomy in Denmark. An analysis of postoperative hospitalisation, morbidity and readmission. Ugeskr Laeger. 2002;164(39):4539.

157. Ottesen M. Validity of the registration and reporting of vaginal prolapse surgery [in Danish: Validitet af kodning og indberetning ved vaginal prolapskirurgi]. Ugeskr Laeger. 2009;171(6):404-408.

158. Lass P, Lilholt J, Thomsen L, Lundbye-Christensen S, Enevoldsen $\mathrm{H}$, Simonsen $\mathrm{OH}$. The quality of diagnosis and procedure coding in Orthopaedic surgery Northern Jutland [in Danish: Kvaliteten af diagnose- og procedurekodning i Ortopaedkirurgi Nordjylland]. Ugeskr Laeger. 2006;168(48): 4212-4215.

159. Andersen LV, Mortensen LS, Lindholt JS, Faergeman O, Henneberg EW, Frost L. Completeness and positive predictive value of registration of upper limb embolectomy in the Danish national vascular registry. Clin Epidemiol. 2009;1:27-32.

160. Blichert-Hansen L, Nielsson MS, Nielsen RB, Christiansen CF, Nørgaard M. Validity of the coding for intensive care admission, mechanical ventilation, and acute dialysis in the Danish national patient registry: a short report. Clin Epidemiol. 2013;5:9-12.

161. Lund JL, Frøslev T, Deleuran T, et al. Validity of the Danish national registry of patients for chemotherapy reporting among colorectal cancer patients is high. Clin Epidemiol. 2013;5:327-334.

162. Nielsson MS, Erichsen R, Frøslev T, Taylor A, Acquavella J, Ehrenstein V. Positive predictive values of the coding for bisphosphonate therapy among cancer patients in the Danish national patient registry. Clin Epidemiol. 2012;4:233-236.
163. Haerskjold A, Henriksen L, Way S, et al. The Danish national prescription registry in studies of a biological pharmaceutical: palivizumab \&ndash; validation against two external data sources. Clin Epidemiol. 2015;7:305-312.

164. Nielsen LH, Nørgaard BL, Tilsted HH, et al. The Western Denmark cardiac computed tomography registry: a review and validation study. Clin Epidemiol. 2015;7:53-64.

165. Brown LD, Cai TT, DasGupta A. Interval estimation for a binomial proportion. Stat Sci. 2001;16:101-117.

166. Erichsen R, Lash TL, Hamilton-Dutoit SJ, Bjerregaard B, Vyberg M, Pedersen L. Existing data sources for clinical epidemiology: the Danish national pathology registry and data bank. Clin Epidemiol. 2010;2:51-56.

167. Grann AF, Erichsen R, Nielsen AG, Frøslev T, Thomsen RW. Existing data sources for clinical epidemiology: the clinical laboratory information system (LABKA) research database at Aarhus university, Denmark. Clin Epidemiol. 2011;3:133-138.

168. Kildemoes HW, Sørensen H, Hallas J. The Danish national prescription registry. Scand J Public Health. 2011;39(7 Suppl):38-41.

169. Christiansen C, Johansen M, Christensen S, O'Brien JM, Tønnesen E, Sørensen H. Preadmission metformin use and mortality among intensive care patients with diabetes: a cohort study. Crit Care. 2013; 17(5):R192.

170. Schmidt M, Jacobsen JB, Lash TL, Bøtker HE, Sørensen HT. 25 year trends in first time hospitalisation for acute myocardial infarction, subsequent short and long term mortality, and the prognostic impact of sex and comorbidity: a Danish nationwide cohort study. BMJ. 2012;344:e356.

171. Sørensen HT, Mellemkjær L, Steffensen FH, Olsen JH, Nielsen GL. The risk of a diagnosis of cancer after primary deep venous thrombosis or pulmonary embolism. $N$ Engl J Med. 1998;338(17):1169-1173.

172. Roos NP, Wennberg JE, Malenka DJ, et al. Mortality and reoperation after open and transurethral resection of the prostate for benign prostatic hyperplasia. N Engl J Med. 1989;320(17):1120-1124.

173. Frost L, Vukelic Andersen L, Mortensen LS, Dethlefsen C. Seasonal variation in stroke and stroke-associated mortality in patients with a hospital diagnosis of nonvalvular atrial fibrillation or flutter. A population-based study in Denmark. Neuroepidemiology. 2006; 26(4):220-225.

174. Schmidt M, Christiansen CF, Mehnert F, Rothman KJ, Sørensen HT. Non-steroidal anti-inflammatory drug use and risk of atrial fibrillation or flutter: population based case-control study. BMJ. 2011;343:d3450.

175. Schmidt M, Bøtker HE, Pedersen L, Sørensen HT. Comparison of the frequency of atrial fibrillation in young obese versus young nonobese men undergoing examination for fitness for military service. Am J Cardiol. 2014;113(5):822-826.

176. Christensen AI, Ekholm O, Glümer C, et al. The Danish national health survey 2010. Study design and respondent characteristics. Scand $J$ Public Health. 2012;40(4):391-397.

177. Center for Public Health and Quality Improvement, Central Denmark Region. How Are You? Available from: http://www.cfk.rm.dk/om-cfk/ projektsite/hvordan-har-du-det/om-undersogelsen/. Accessed October $1,2015$.

178. Tjønneland A, Olsen A, Boll K, et al. Study design, exposure variables, and socioeconomic determinants of participation in diet, cancer and health: a population-based prospective cohort study of 57,053 men and women in Denmark. Scand J Public Health. 2007;35(4):432-441.

179. Mikkelsen EM, Hatch EE, Wise LA, Rothman KJ, Riis A, Sørensen HT. Cohort profile: the Danish web-based pregnancy planning study 'Snart-Gravid'. Int J Epidemiol. 2009;38(4):938-943.

180. Osler M, Linneberg A, Glümer C, Jørgensen T. The cohorts at the research centre for prevention and health, formerly 'the Glostrup population studies'. Int J Epidemiol. 2011;40(3):602-610.

181. Schnohr P, Jensen G, Lange P, Scharling H. The Copenhagen city heart study. Østerbroundersøgelsen: tables with data from the third examination 1991-1994. Eur Heart J Suppl. 2001;3:(suppl H) H1-H83. 
182. Hjertholm P, Fenger-Grøn M, Vestergaard M, et al. Variation in general practice prostate-specific antigen testing and prostate cancer outcomes: an ecological study. Int J Cancer. 2015;136(2):435-442.

183. Christiansen EH, Jensen LO, Thayssen P, et al; Scandinavian Organization for Randomized Trials with Clinical Outcome (SORT OUT) V investigators. Biolimus-eluting biodegradable polymercoated stent versus durable polymer-coated sirolimus-eluting stent in unselected patients receiving percutaneous coronary intervention (SORT OUT V): a randomised non-inferiority trial. Lancet 2013;381(9867):661-669.

184. Thuesen L, Jensen LO, Tilsted HH, et al. Event detection using population-based health care databases in randomized clinical trials: a novel research tool in interventional cardiology. Clin Epidemiol. 2013;5:357-361.

185. Sloth AD, Schmidt MR, Munk K, et al; CONDI Investigators. Improved long-term clinical outcomes in patients with ST-elevation myocardial infarction undergoing remote ischaemic conditioning as an adjunct to primary percutaneous coronary intervention. Eur Heart J. 2014;35(3):168-175.

186. Nielsen PH, Maeng M, Busk M, et al; DANAMI-2 Investigators. Primary angioplasty versus fibrinolysis in acute myocardial infarction: long-term follow-up in the Danish acute myocardial infarction 2 trial. Circulation. 2010;121(13):1484-1491.

187. Jespersen CM, Als-Nielsen B, Damgaard M, et al; CLARICOR Trial Group. Randomised placebo controlled multicentre trial to assess short term clarithromycin for patients with stable coronary heart disease: CLARICOR trial. BMJ. 2006;332(7532):22-27.

188. Pedersen AT, Lidegaard Ø, Kreiner S, Ottesen B. Hormone replacement therapy and risk of non-fatal stroke. Lancet. 1997;350(9087): $1277-1283$

189. Andersen BS, Olsen J. Oral contraception and factor V Leiden mutation in relation to localization of deep vein thrombosis. Thromb Res. 1998;90(4):191-194.

190. Vest-Hansen B, Riis AH, Sørensen HT, Christiansen CF. Out-of-hours and weekend admissions to Danish medical departments: admission rates and 30-day mortality for 20 common medical conditions. BMJ Open. 2015;5(3):e006731-e006731.

191. Thygesen LC, Ersbøll AK, editors. Danish population-based registers for public health and health-related welfare research. Scand J Public Health. 2011;39(7 Suppl):8-10.

192. Andersen JS, Olivarius NDF, Krasnik A. The Danish national health service register. Scand J Public Health. 2011;39(7 Suppl):34-37.

193. Statistics Denmark. The Integrated Database for Labour Market Researc. [In Danish: Den Integrerede Database for Arbejdsmarkedsforskning]; 2013:1-6. Available from: http://www.dst.dk/da/Statistik/ Publikationer/VisPub.aspx?cid=20698. Accessed April 1, 2015.

194. Jensen VM, Rasmussen AW. Danish education registers. Scand J Public Health. 2011;39(7 Suppl):91-94.

195. Baadsgaard M, Quitzau J. Danish registers on personal income and transfer payments. Scand J Public Health. 2011;39(7 Suppl):103-105.

196. Christensen G. The building and housing register. Scand J Public Health. 2011;39(7 Suppl):106-108.

197. Johannesdottir SA, Horvath-Puho E, Ehrenstein V, Schmidt M, Pedersen L, Sørensen HT. Existing data sources for clinical epidemiology: the Danish national database of reimbursed prescriptions. Clin Epidemiol. 2012;4:303-313.

198. Helweg-Larsen K. The Danish register of causes of death. Scand J Public Health. 2011;39(7 Suppl):26-29.

199. Harvald B, Hauge G, Kyvik KO, Christensen K, Skytthe A, Holm NV. The Danish twin registry: past and present. Twin Res. 2004;7(4): 318-335.

200. Databasernes fællessekretariat. Information on the Danish Clinical Registries. Available from: http://www.rkkp.dk/in-english/. Accessed August 1, 2015

201. The Danish e-Health Portal. Description of all Danish Clinical Registries (in Danish). Available from: http://www.sundhed.dk/ sundhedsfaglig/kvalitet/kliniske-kvalitetsdatabaser/. Accessed August 1, 2015.
202. Nørgaard M, Jensen AØ, Engebjerg MC, et al. Long-term clinical outcomes of patients with primary chronic immune thrombocytopenia: a Danish population-based cohort study. Blood. 2011;117(13): 3514-3520.

203. Anderson IB, Sørensen TI, Prener A. Increase in incidence of disease due to diagnostic drift: primary liver cancer in Denmark, 1943-1985. BMJ. 1991;302(6774):437-440.

204. Schmidt M, Hováth-Puhó E, Christiansen CF, Petersen KL, Bøtker HE, Sørensen HT. Preadmission use of nonaspirin nonsteroidal antiinflammatory drugs and 30-day stroke mortality. Neurology. 2014; 83(22):2013-2022.

205. Topp M, Langhoff-Roos J, Uldall P. Validation of a cerebral palsy register. J Clin Epidemiol. 1997;50(9):1017-1023.

206. Andersen TF, Madsen M, Loft A. Validity of surgical information from the Danish National Patient Registry with special attention to the analysis of regional variations in hysterectomy rates [in Danish: Regionale variationer i anvendelse af hysterektomi]. Ugeskr Laeger. 1987;149(36):2420-2422.

207. Green A. Danish clinical databases: an overview. Scand J Public Health. 2011;39(7 Suppl):68-71.

208. Ingeholm P. Danish National Colorectal Cancer Database. National Database for Colorectal Cancer. Annual Report 2011; 2012.

209. Sørensen HT, Lash TL, Rothman KJ. Beyond randomized controlled trials: a critical comparison of trials with nonrandomized studies. Hepatology. 2006;44(5):1075-1082.

210. Petersen KE, Johnsen NF, Olsen A, et al. The combined impact of adherence to five lifestyle factors on all-cause, cancer and cardiovascular mortality: a prospective cohort study among Danish men and women. Br J Nutr. 2015;113(5):849-858.

211. Brunelli SM, Gagne JJ, Huybrechts KF, et al. Estimation using all available covariate information versus a fixed look-back window for dichotomous covariates. Pharmacoepidemiol Drug Saf. 2013;22(5): $542-550$.

212. Lidegaard Ø, Løkkegaard E, Jensen A, Skovlund CW, Keiding N. Thrombotic stroke and myocardial infarction with hormonal contraception. N Engl J Med. 2012;366(24):2257-2266.

213. Schmidt M, Pedersen SB, Farkas DK, et al. Thirteen-year nationwide trends in use of implantable cardioverter-defibrillators and subsequent long-term survival. Heart Rhythm. 2015;12(9):2018-2027.

214. Cain KC, Harlow SD, Little RJ, et al. Bias due to left truncation and left censoring in longitudinal studies of developmental and disease processes. Am J Epidemiol. 2011;173(9):1078-1084.

215. Alpert JS, Thygesen K, Antman E, Bassand JP. Myocardial infarction redefined - a consensus document of The Joint European Society of Cardiology/American College of Cardiology Committee for the redefinition of myocardial infarction. J Am Coll Cardiol. 2000;36(3):959-969.

216. Feinstein AR, Sosin DM, Wells CK. The Will Rogers phenomenon. Stage migration and new diagnostic techniques as a source of misleading statistics for survival in cancer. $N$ Engl J Med. 1985;312(25): 1604-1608.

217. Danish Data Protection Agency. The Danish Act on Processing of Personal Data. Available from: http:/www.datatilsynet.dk/english/ the-danish-data-protection-agency/introduction-to-the-danish-dataprotection-agency/. Accessed February 1, 2015.

218. Danish Health and Medicines Authority. Forskerservice. Available from: http://www.ssi.dk/Sundhedsdataogit/Forskerservice.aspx. Accessed April 1, 2015.

219. Danish Health and Medicines Authority. [Videregivelse af patientjournaloplysninger]. Available from: http://sundhedsstyrelsen. $\mathrm{dk} / \mathrm{da} /$ sundhed/behandling-og-rettigheder/patientjournaloplysninger. Accessed April 1, 2015. 


\section{Supplementary materials}

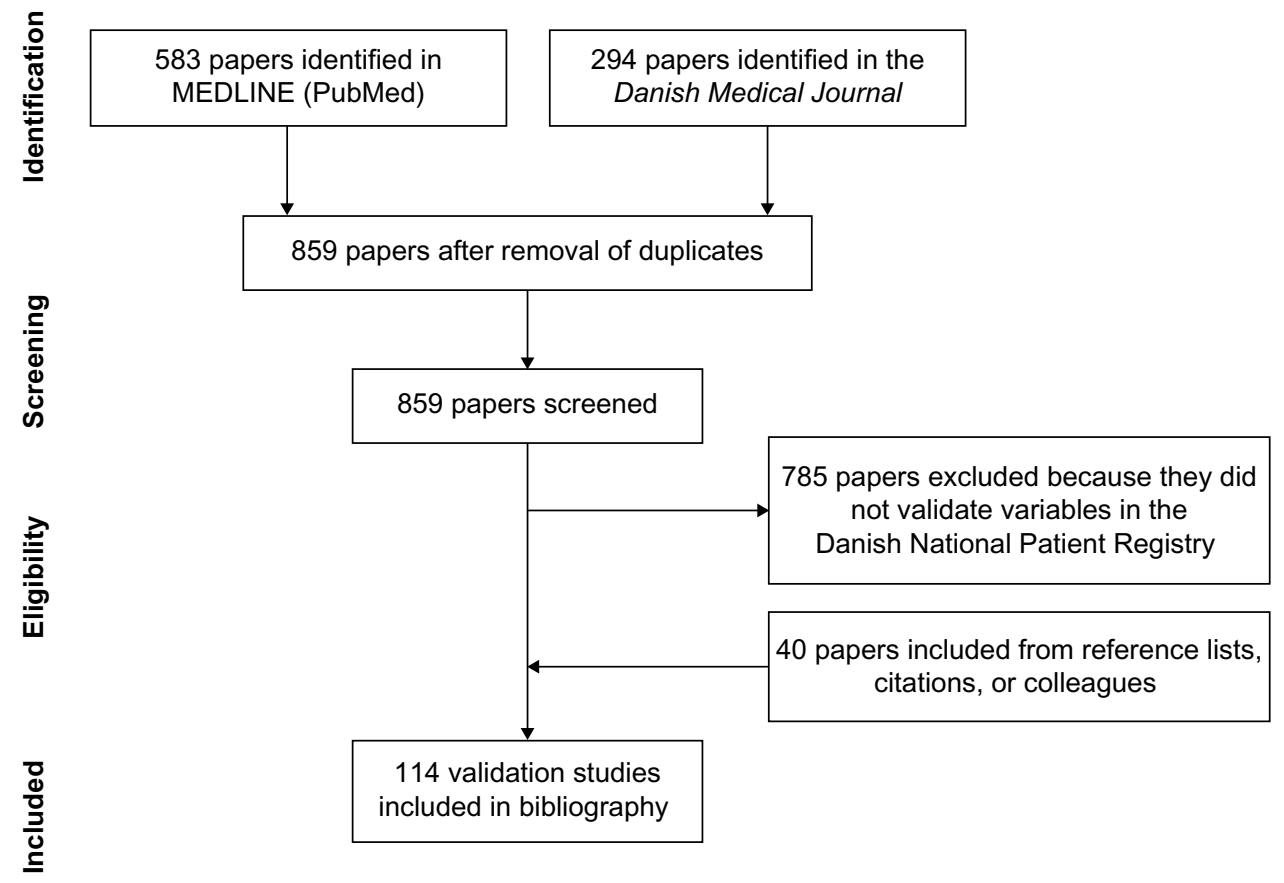

Figure SI Flowchart for the systematic review of validation studies.

Notes: The literature search was performed on July 20, 2015 using the following search string in I) PubMed: "Danish National Patient Registry" OR "Danish National Registry of Patients" OR "Danish National Hospital Register" OR “Danish National Health Registry" OR "Danish National Patient Register" OR "Danish Hospital Discharge Registry" OR “Danish National Hospital Registry" OR “Danish Hospital Registers”; and 2) the Danish Medical Journal: "Landspatientregisteret”. 


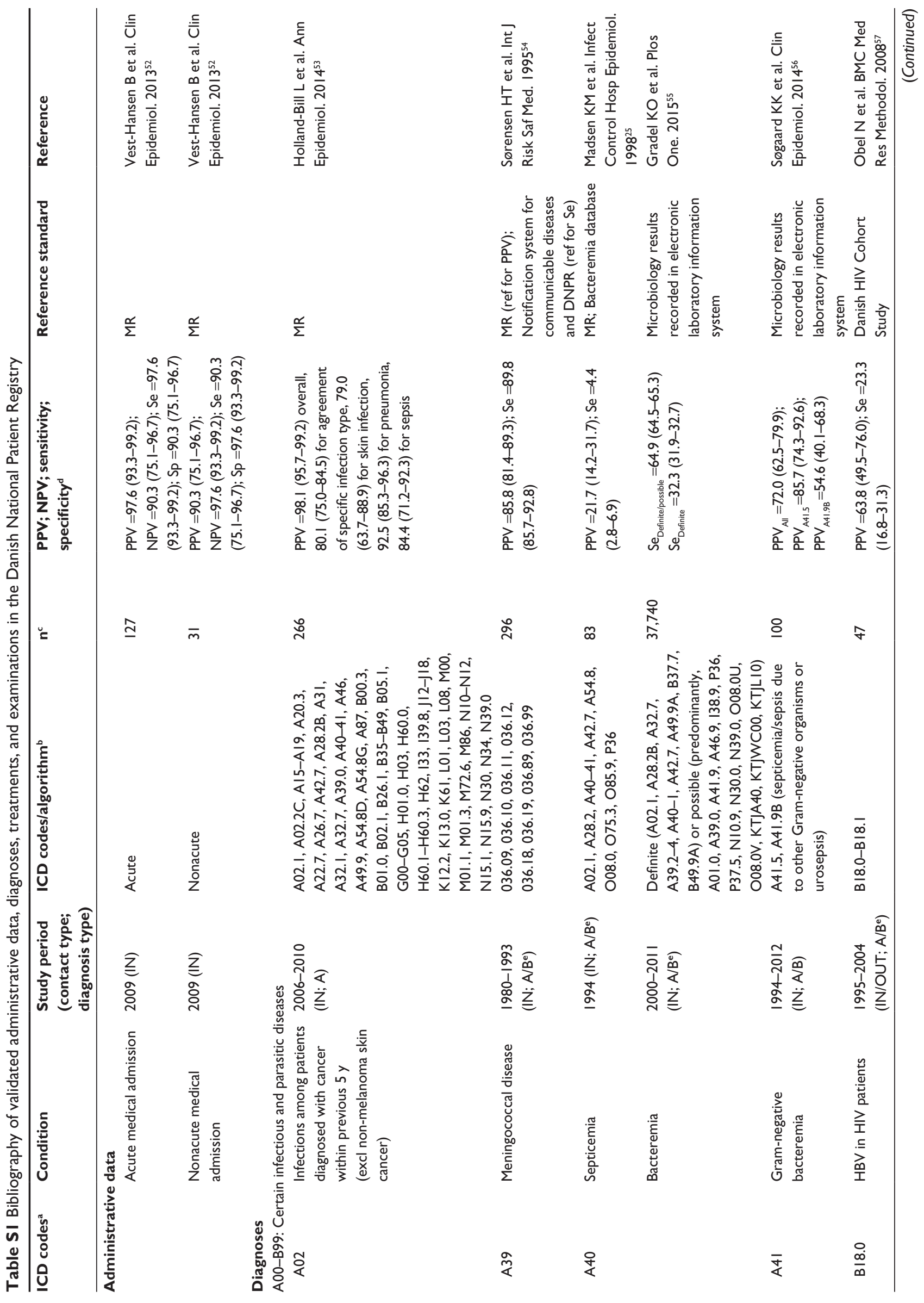




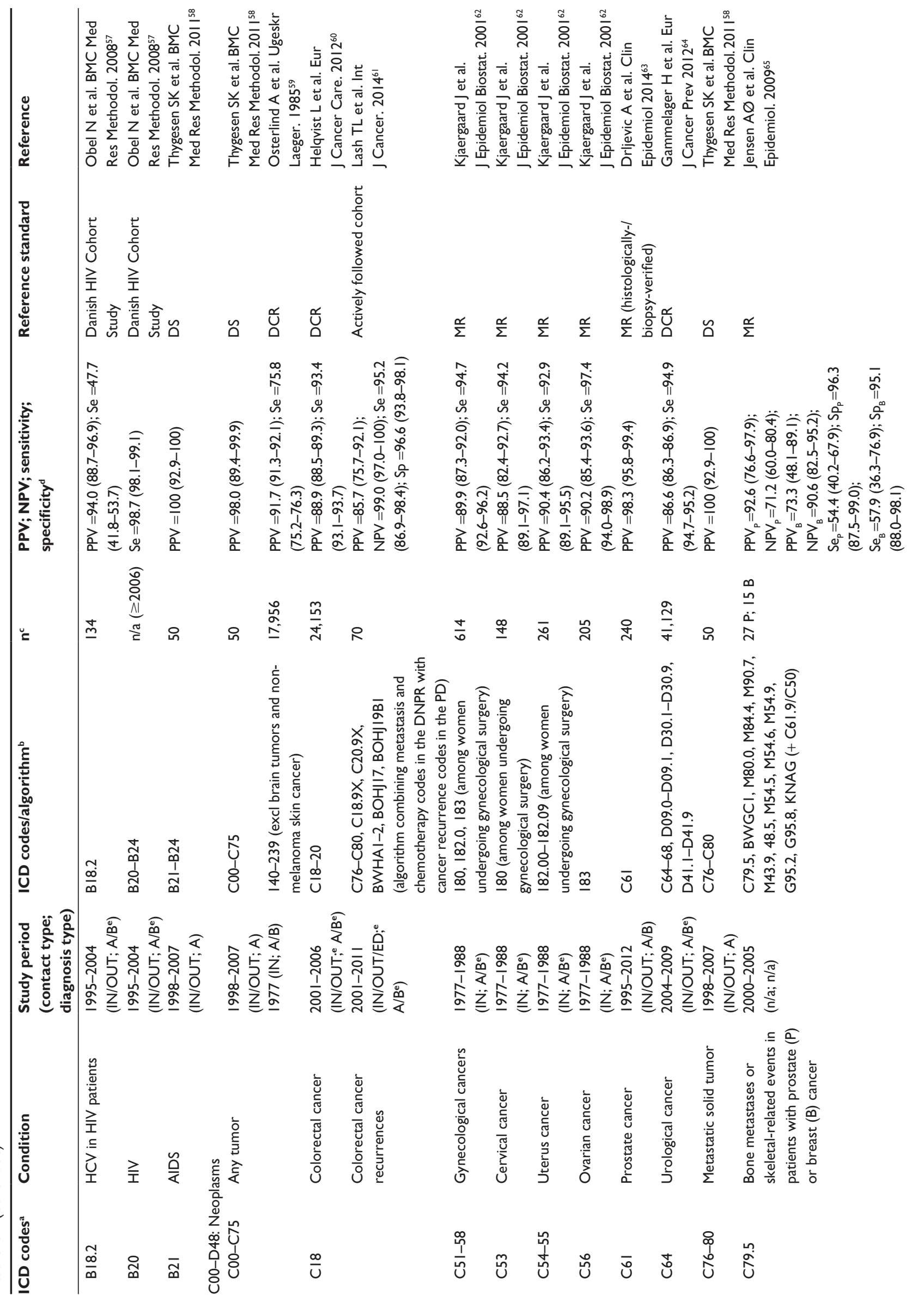




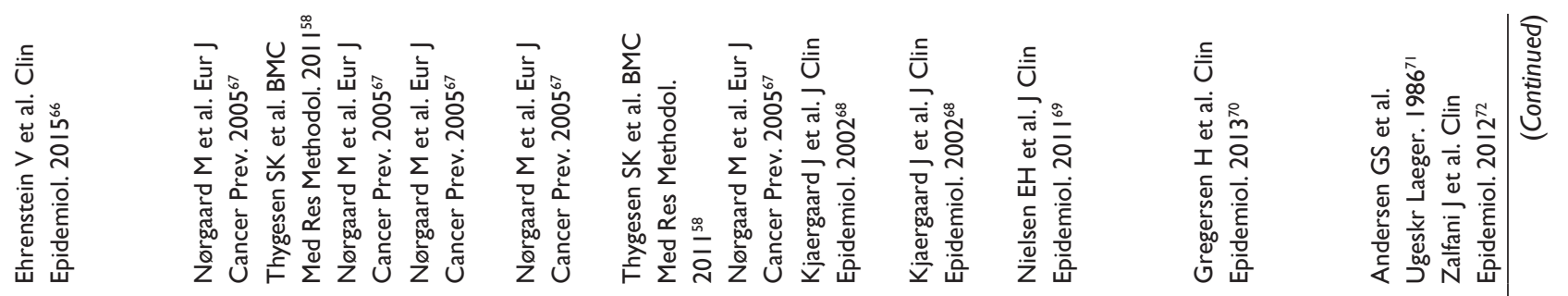

品
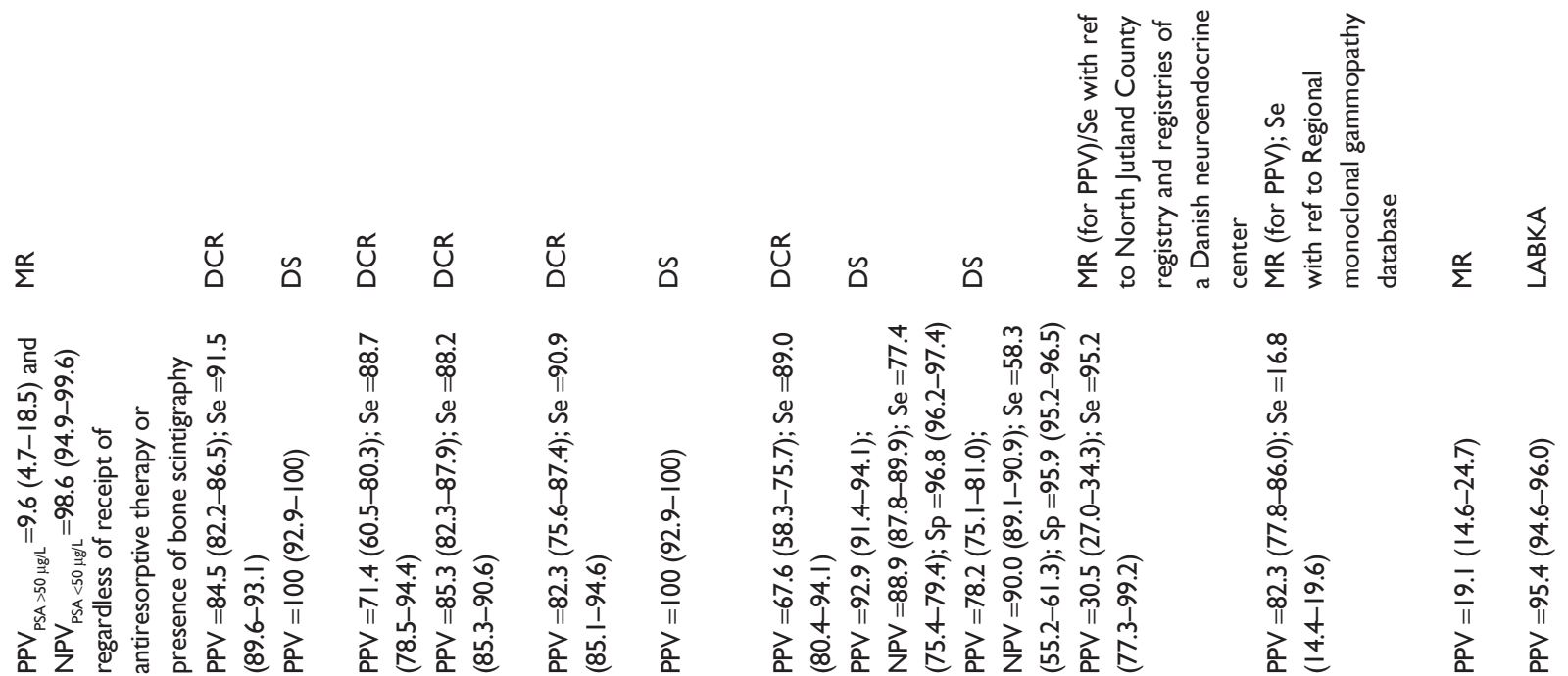

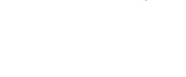
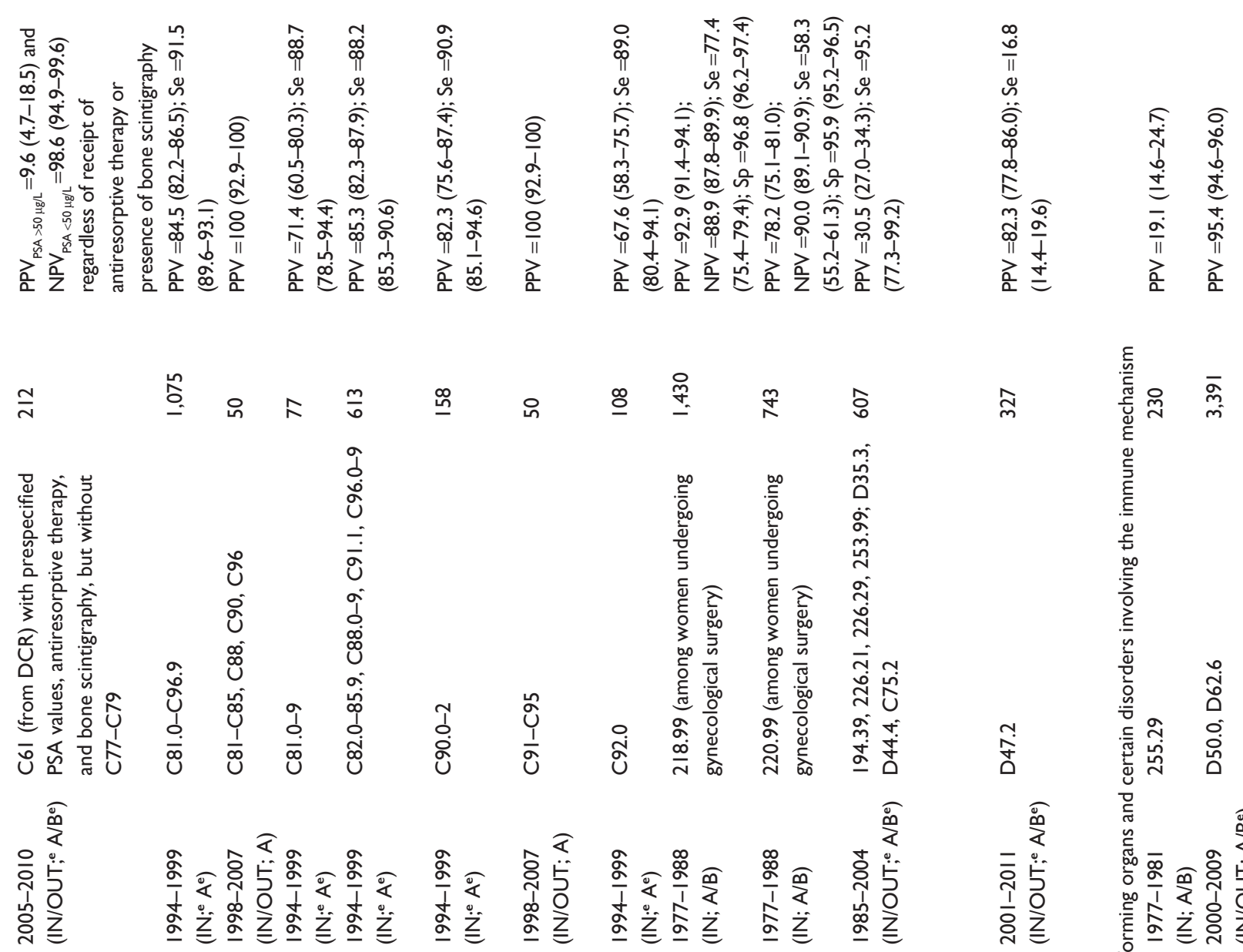

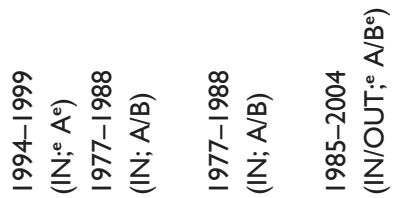
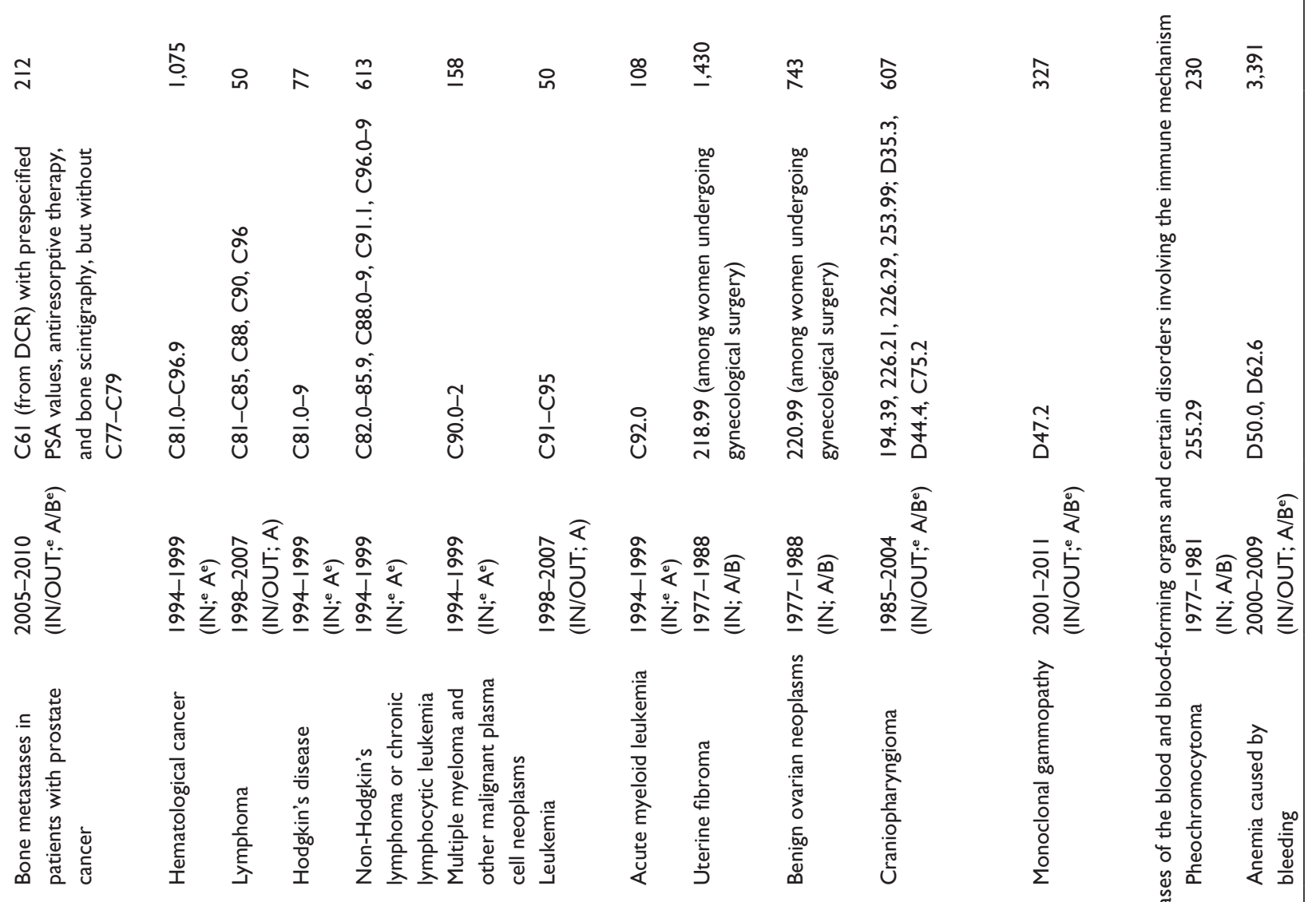

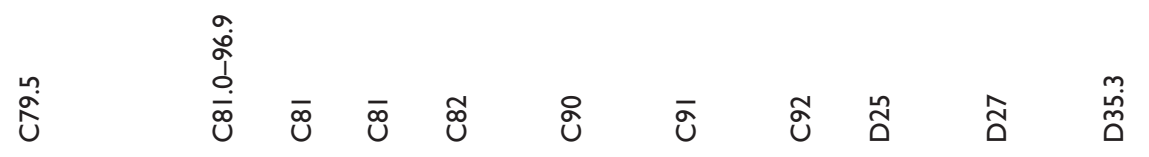

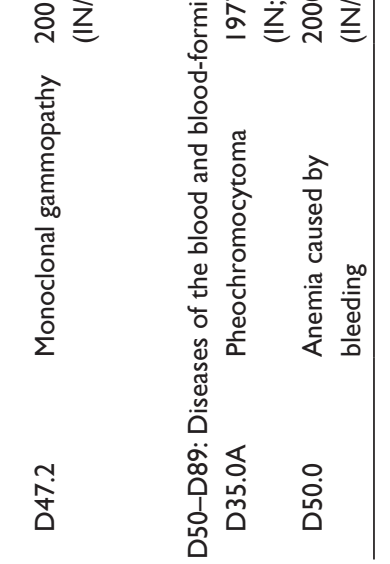




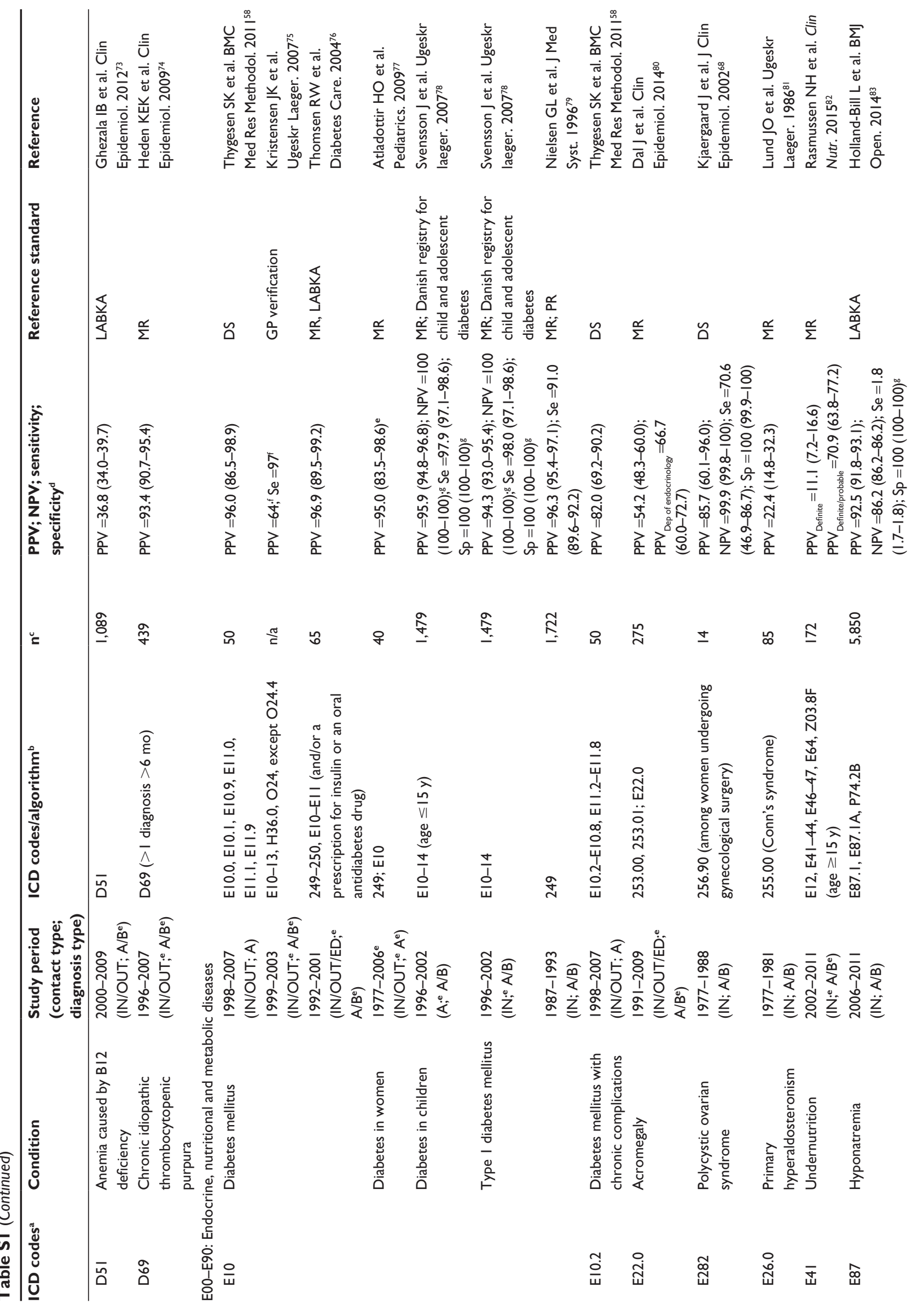




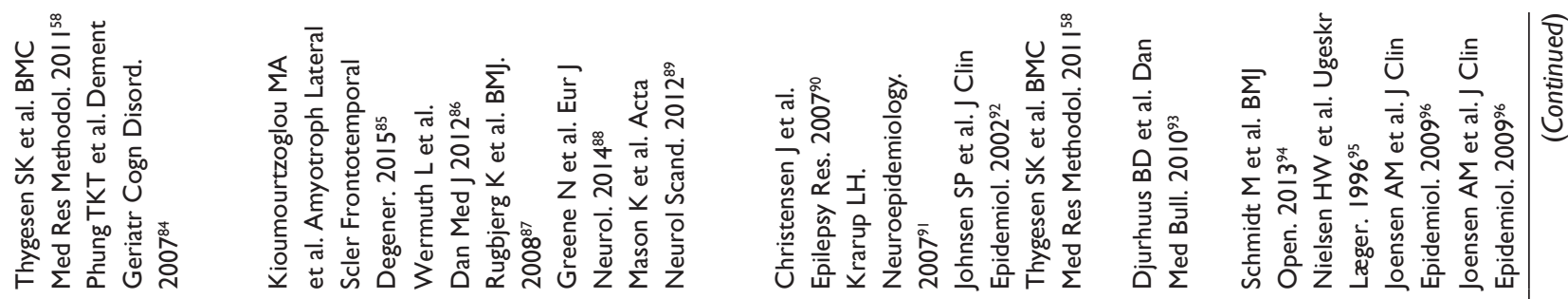

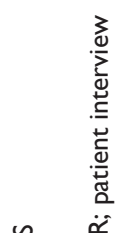

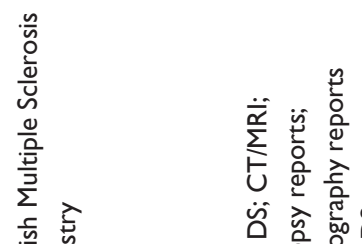

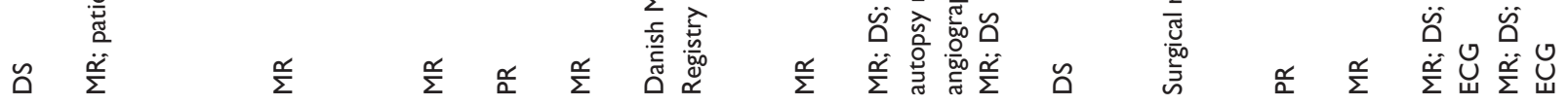

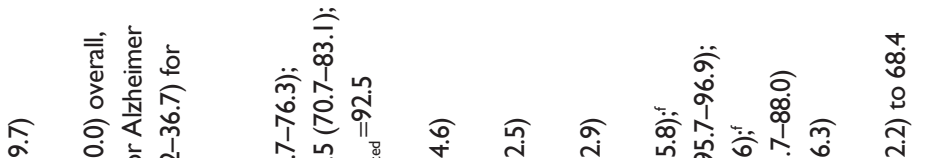

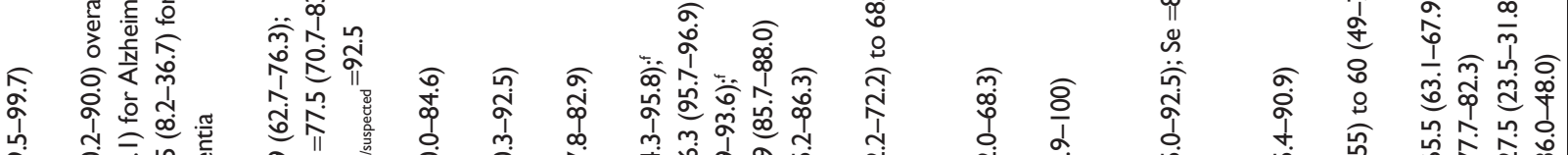

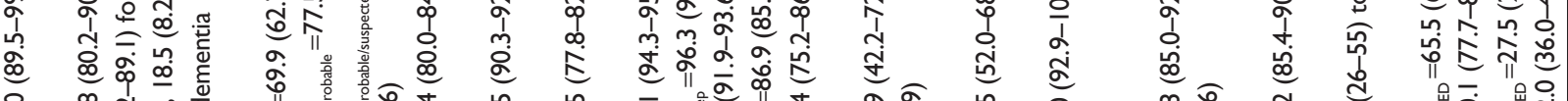

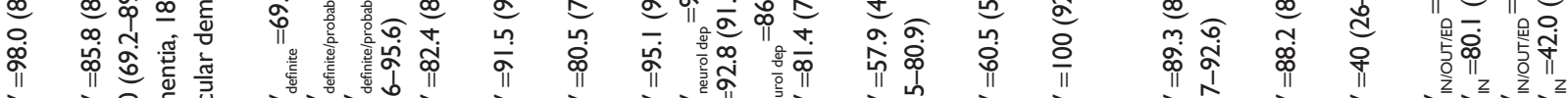

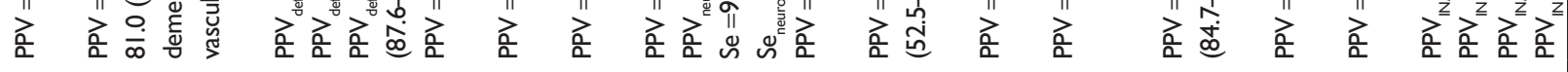

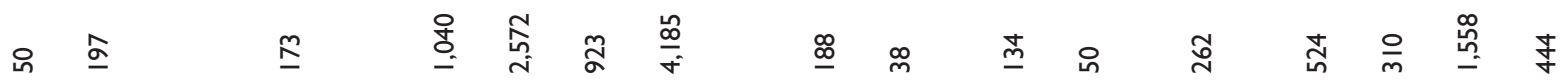

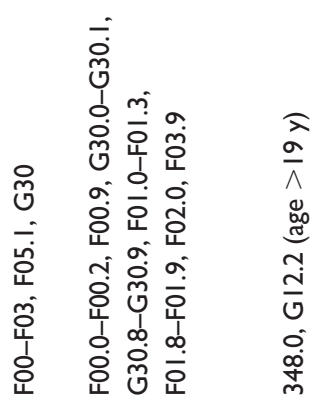

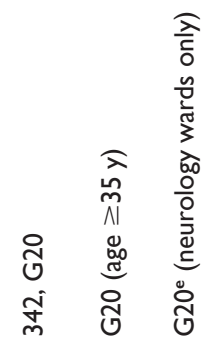
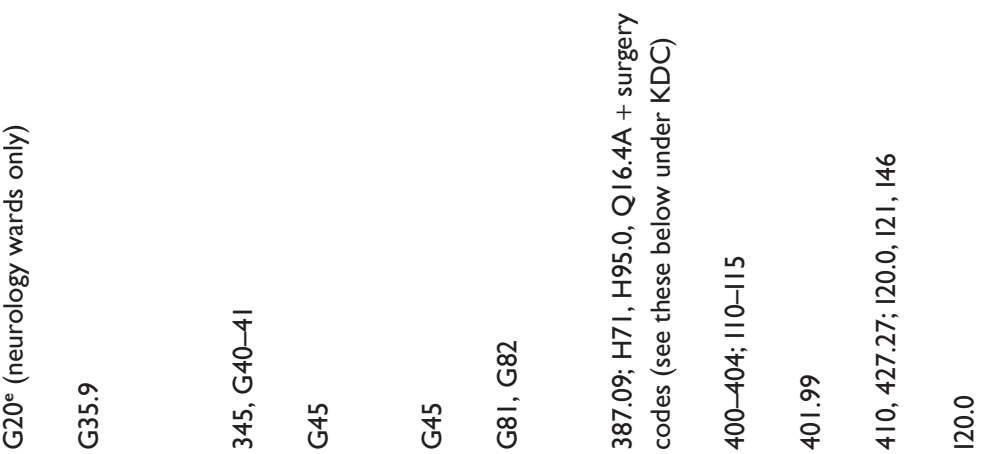

余芺苍

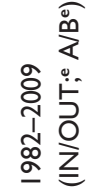

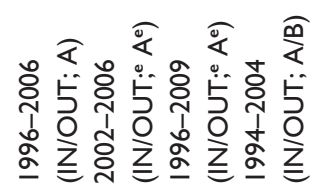

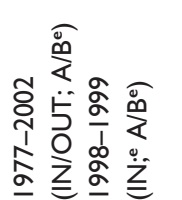

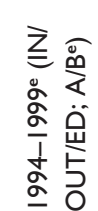

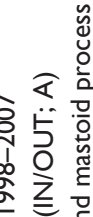

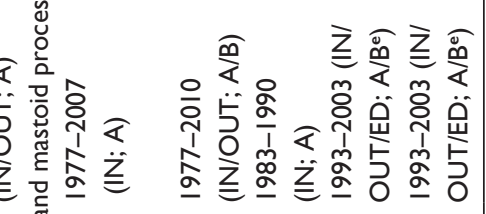
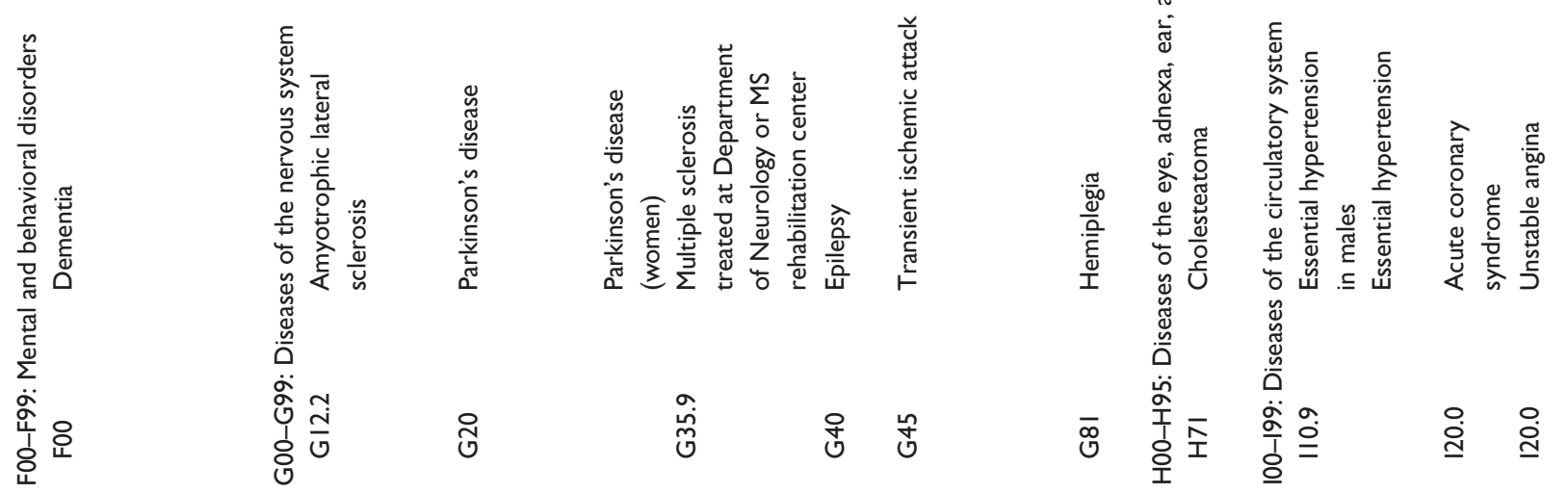


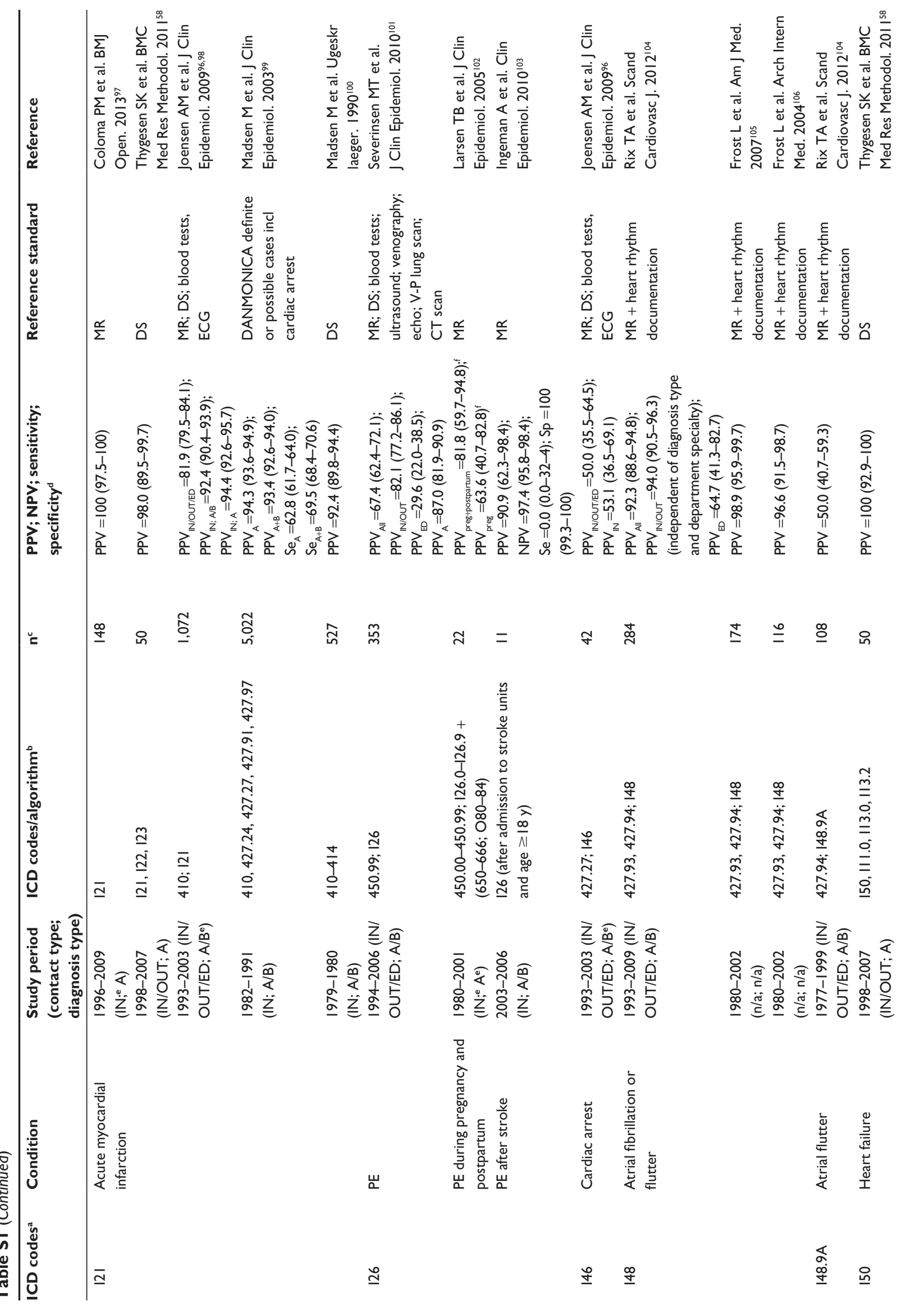




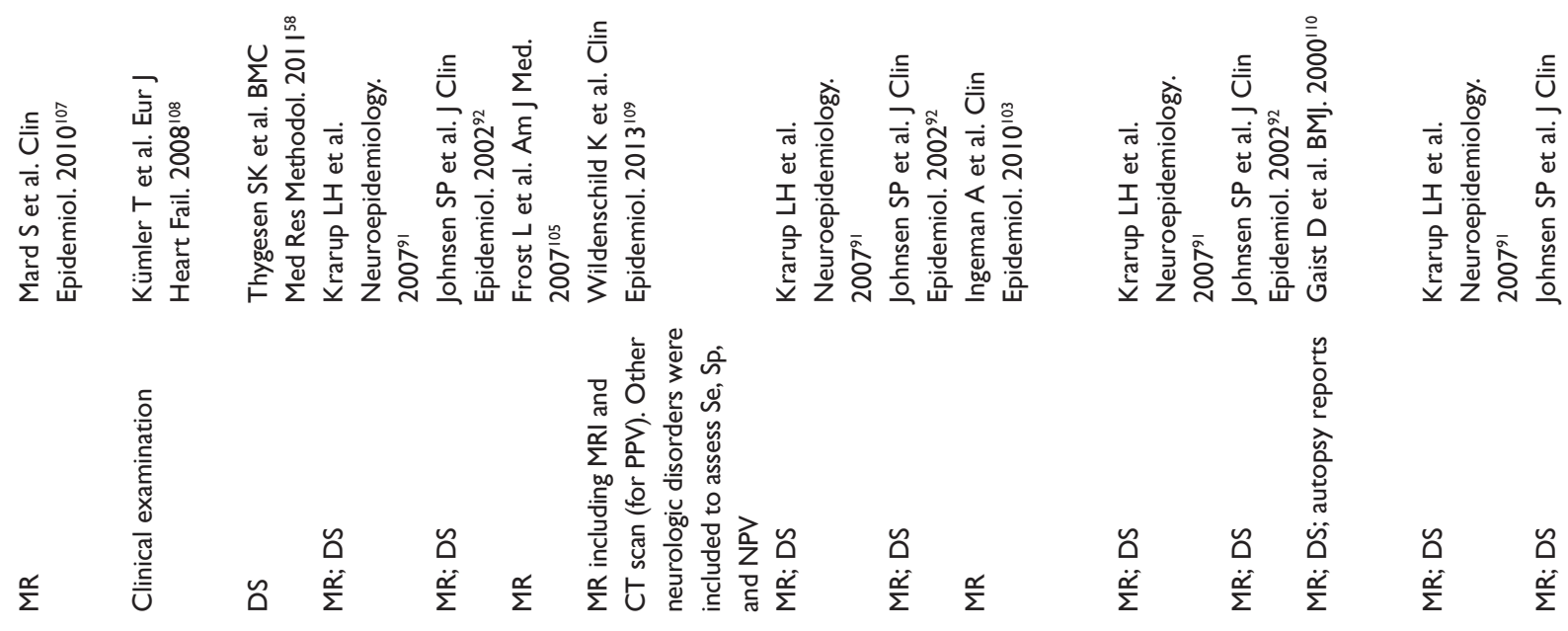

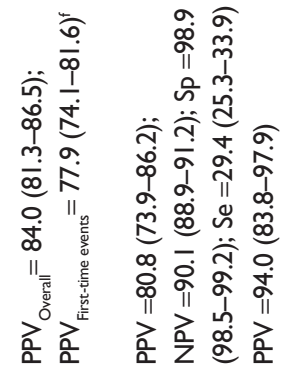

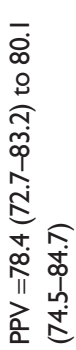

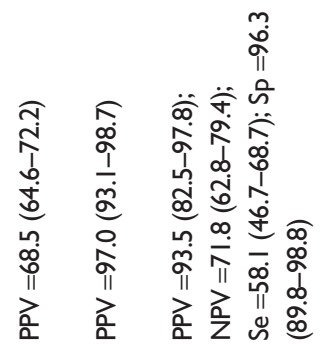

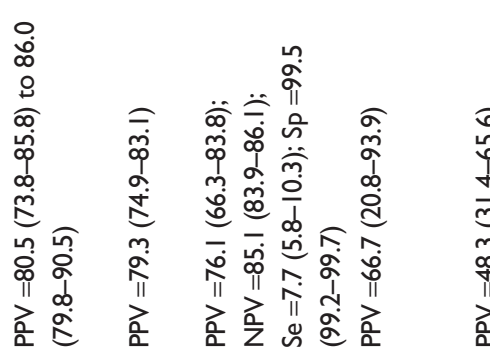

\%ิ

$\stackrel{\infty}{\wedge}$

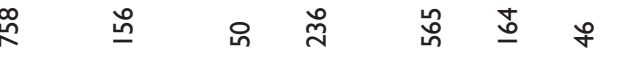

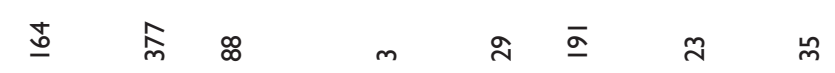
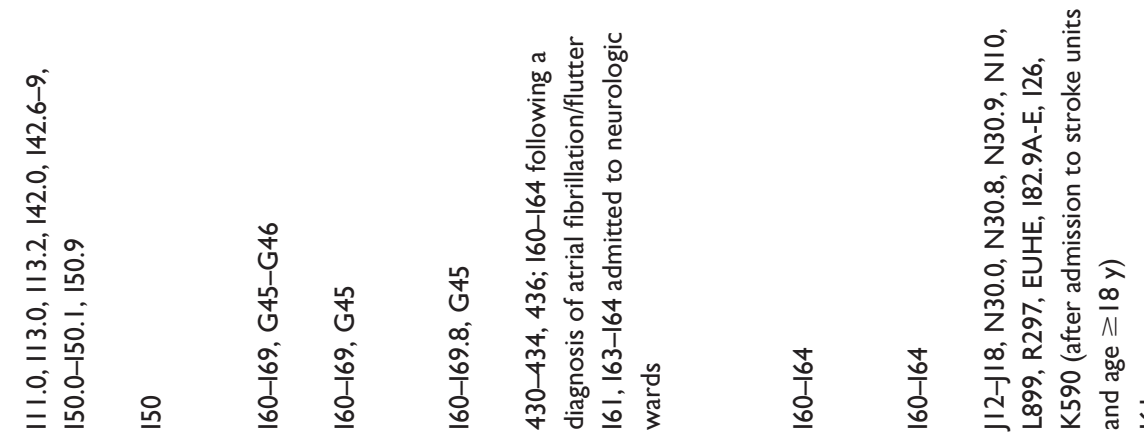

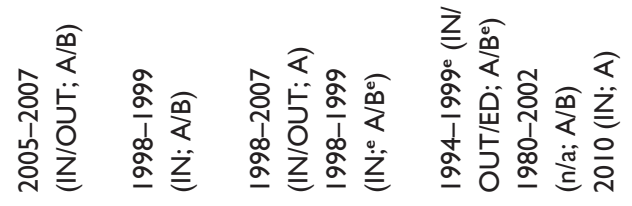

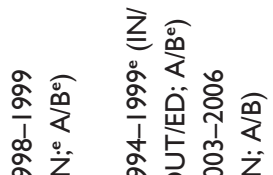

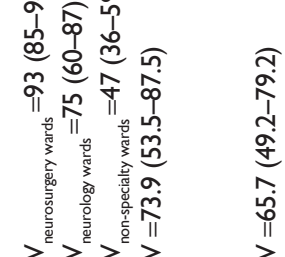

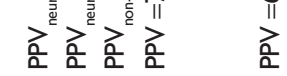
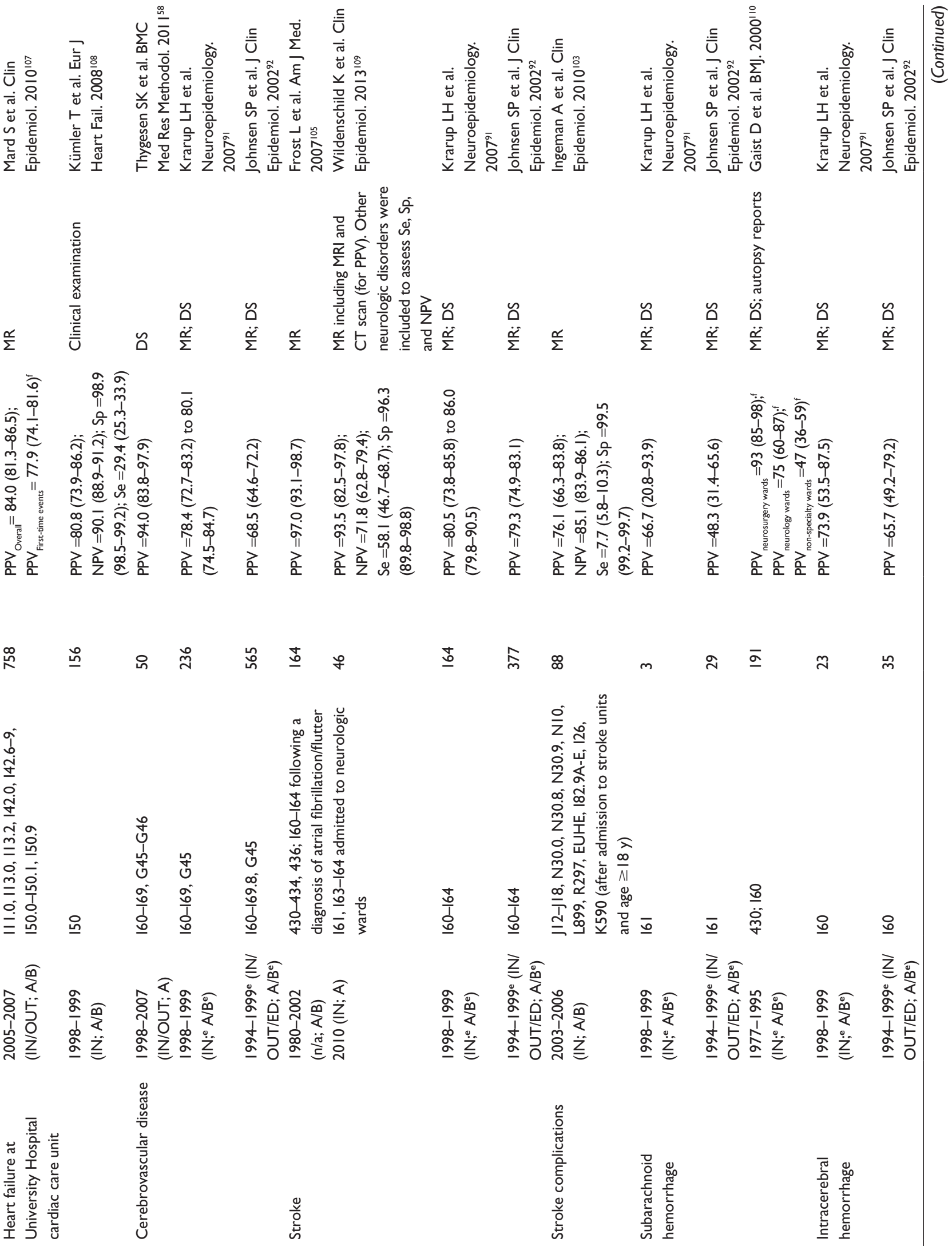

竞
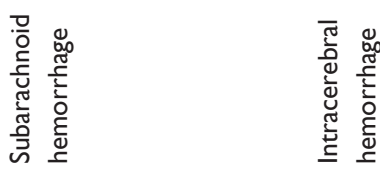

$\underline{0}$

ț
ơ
$\underline{0}$

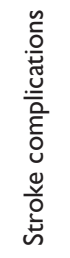

요

$\underline{\overline{ }}$ 


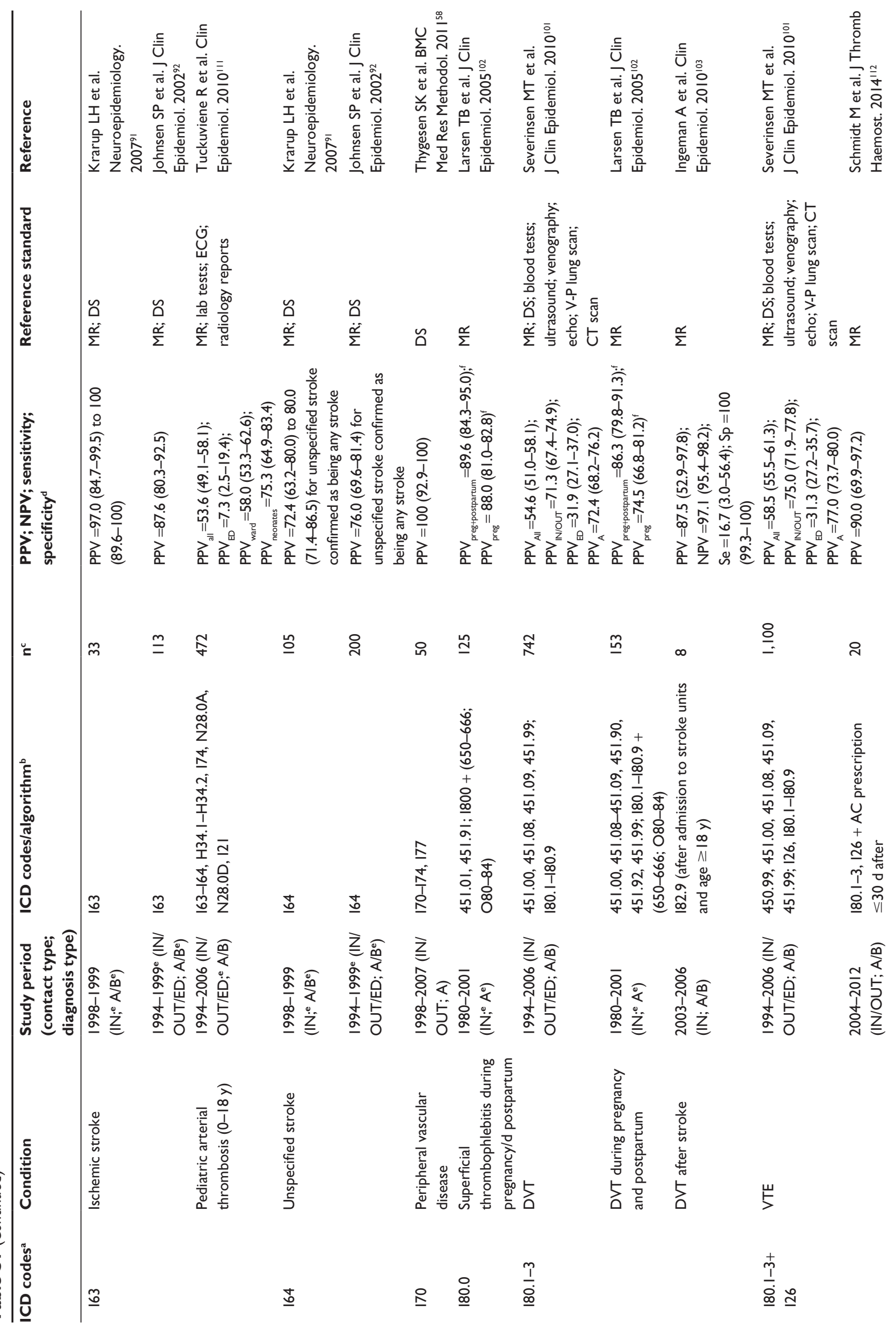




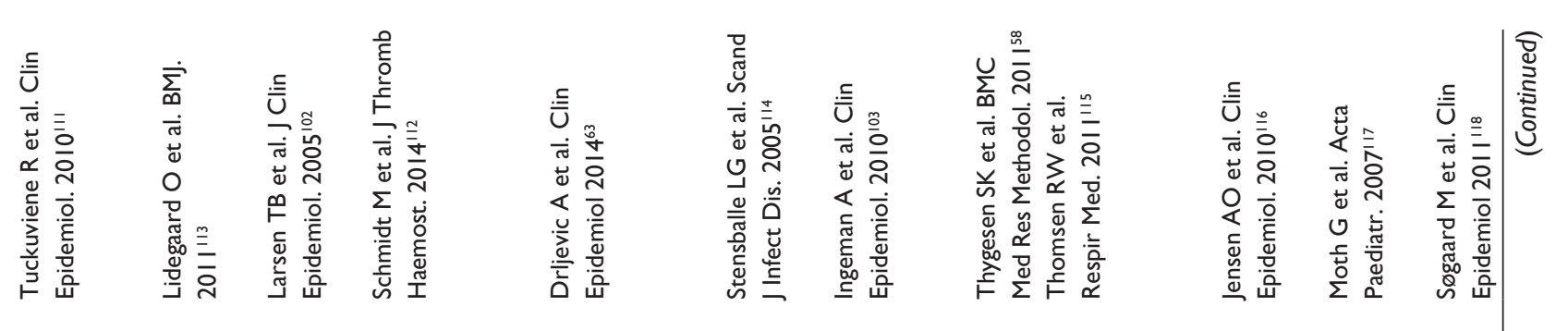

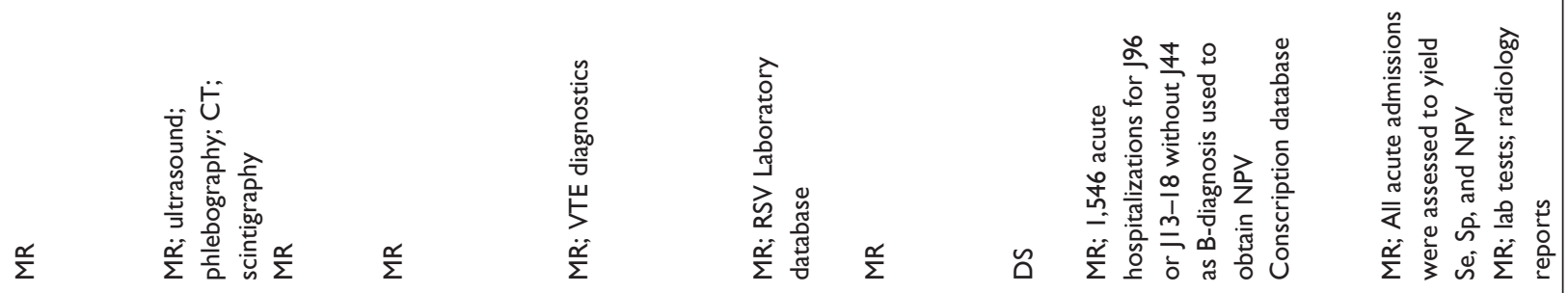

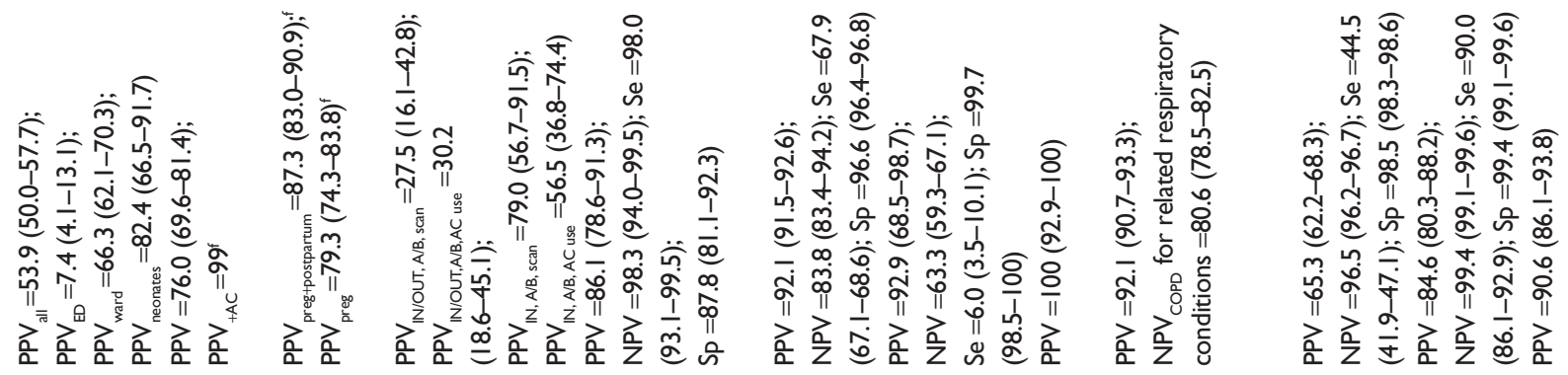

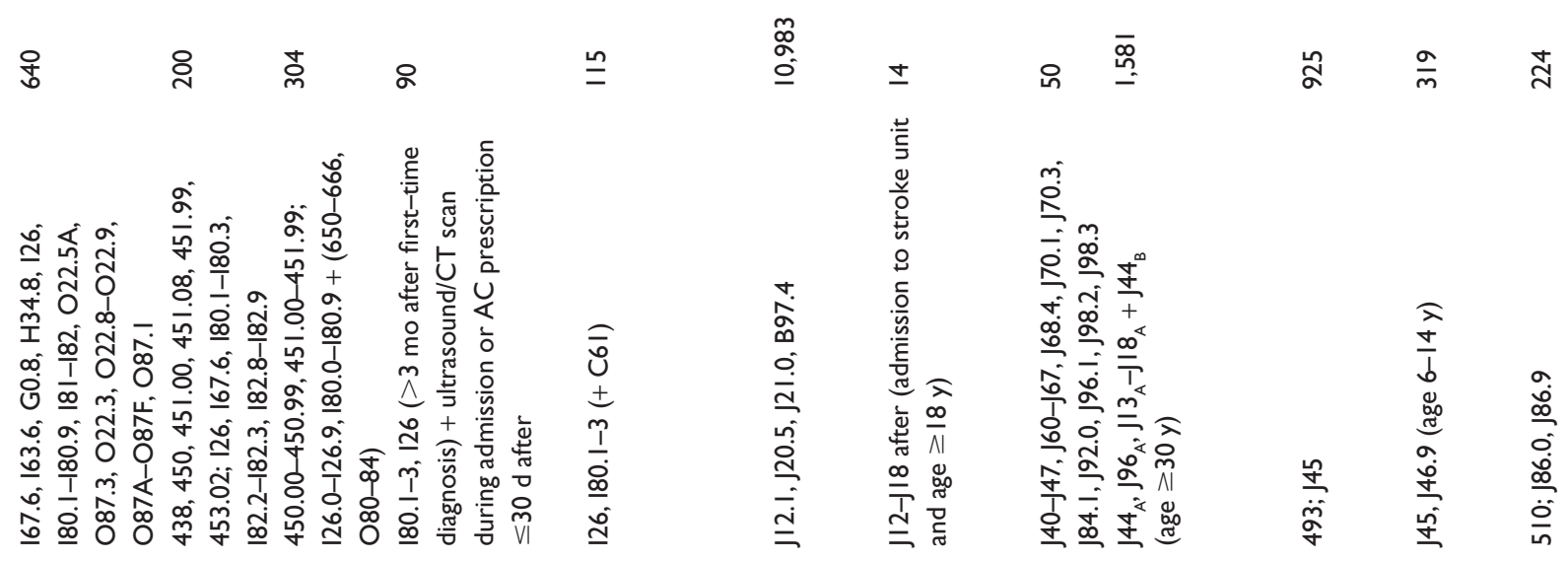

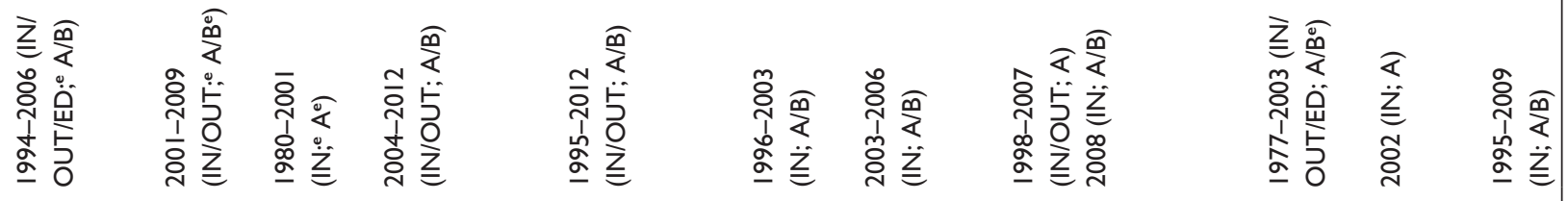

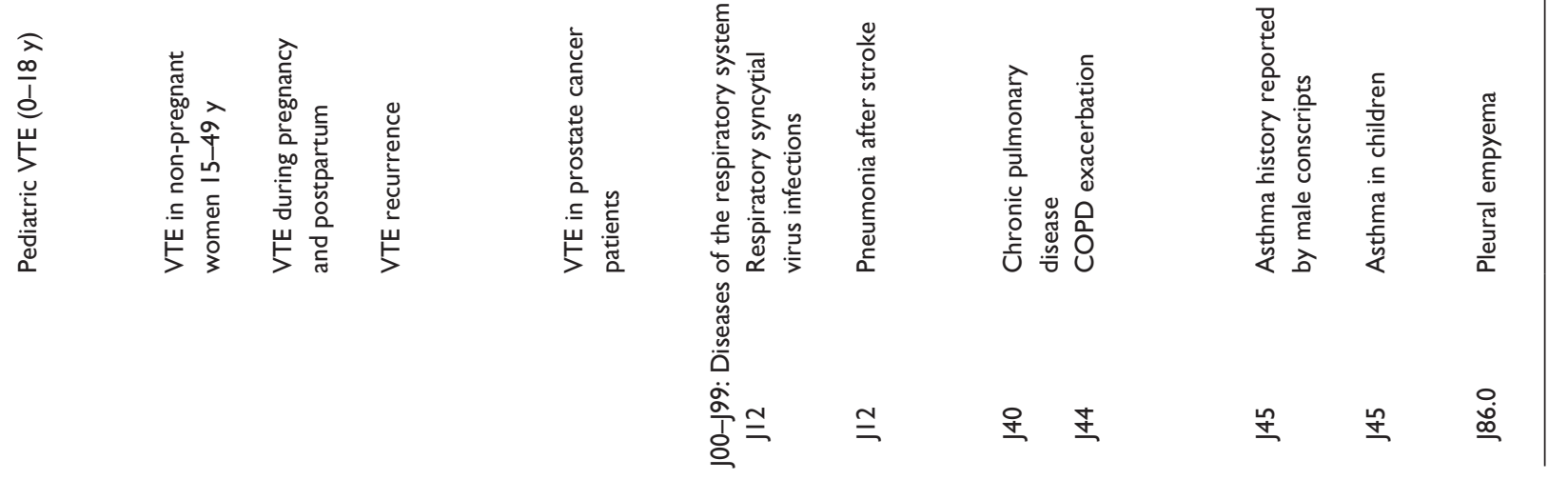




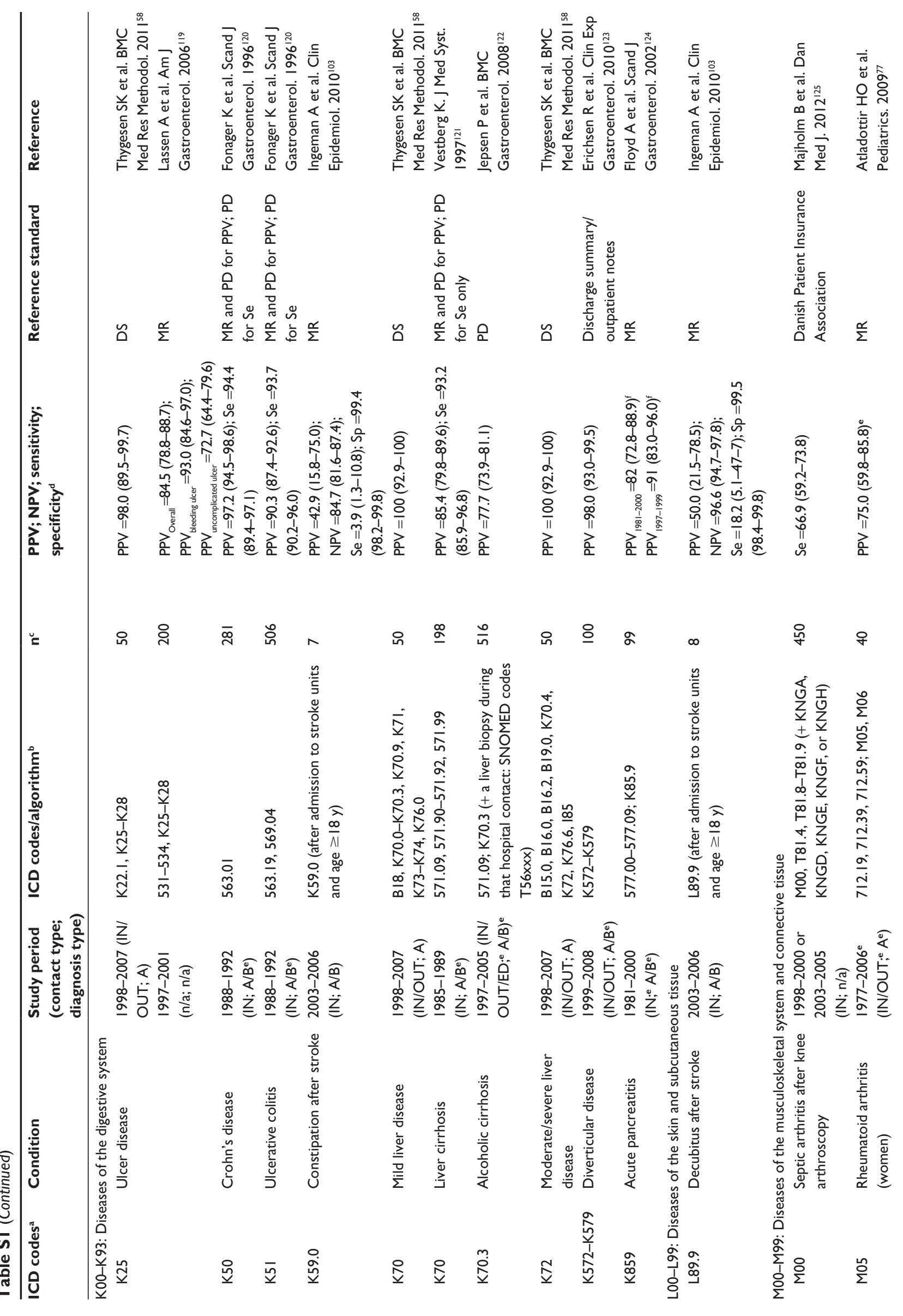




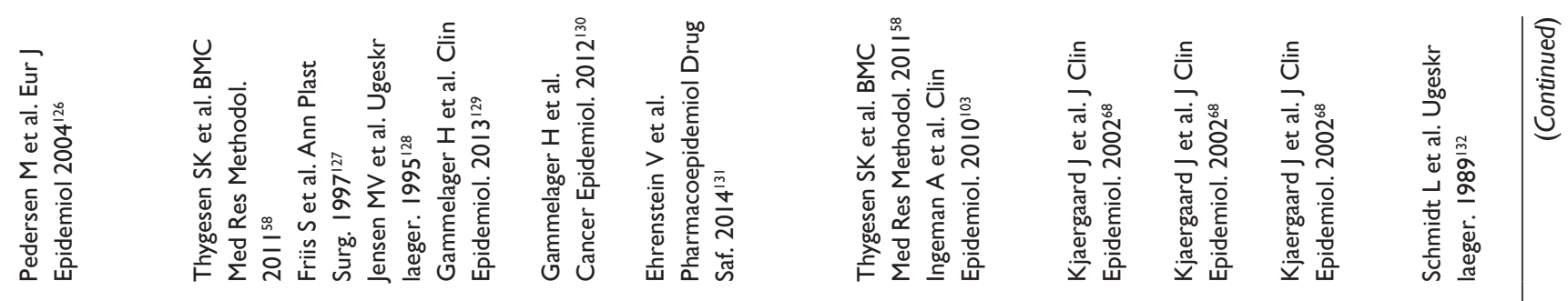

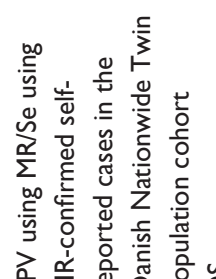

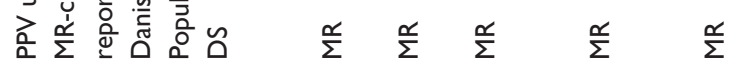
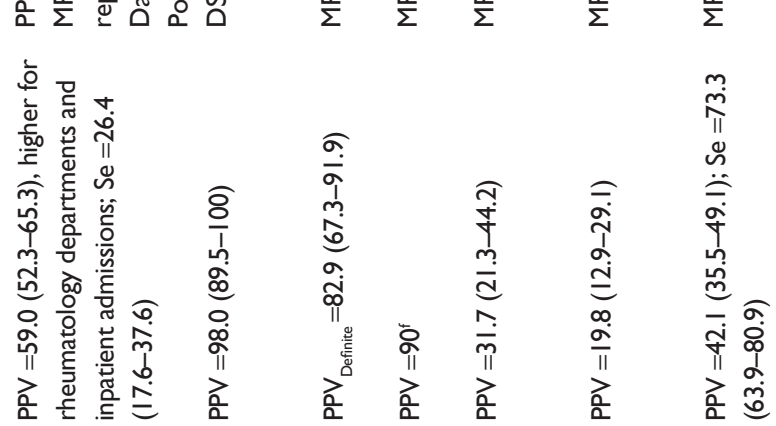

แั

ดั

모

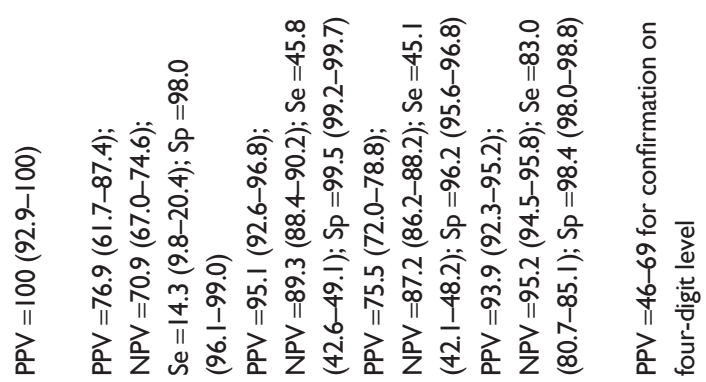

กิ

인

in $\stackrel{\circ}{m}$

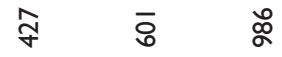

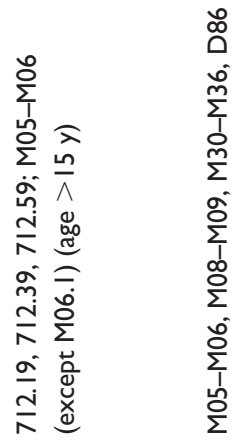

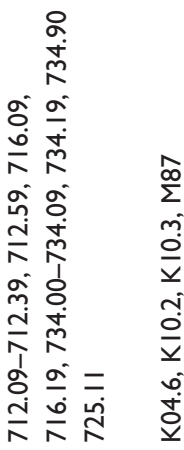

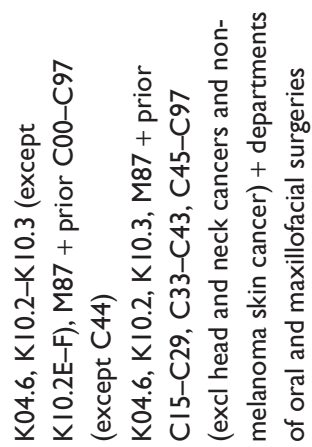

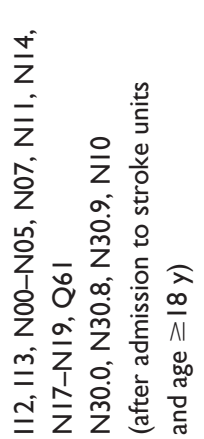

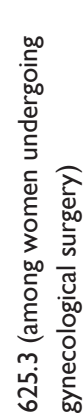

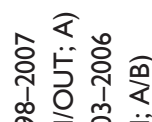

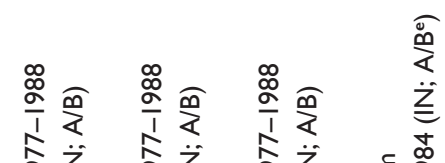

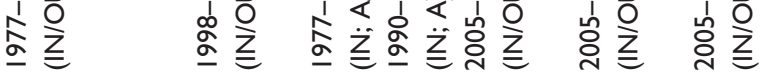

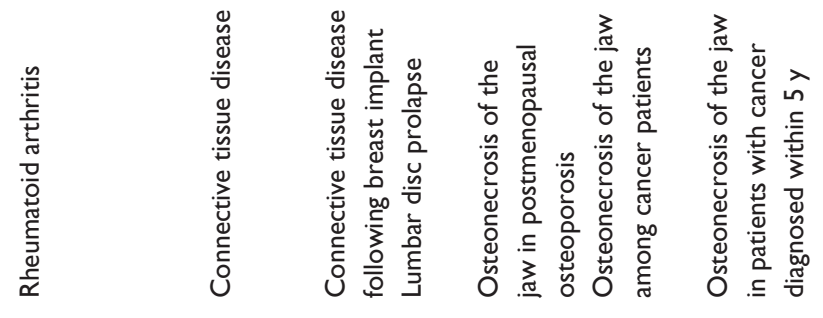

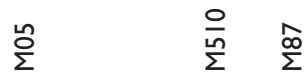

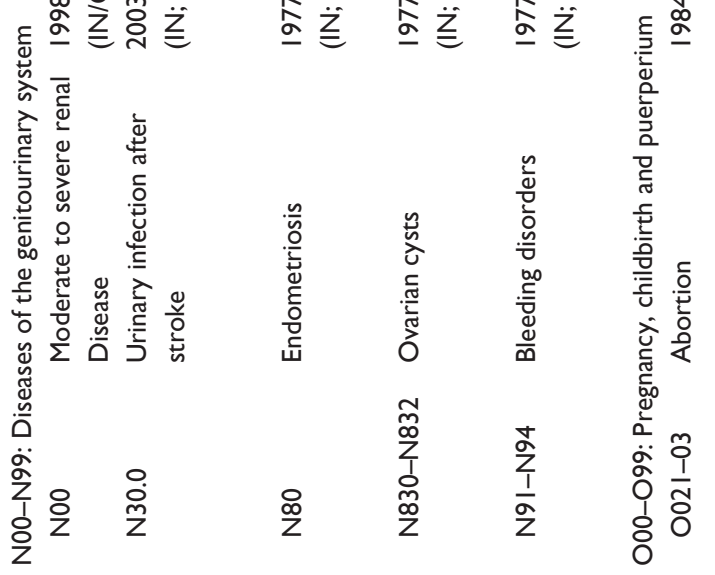




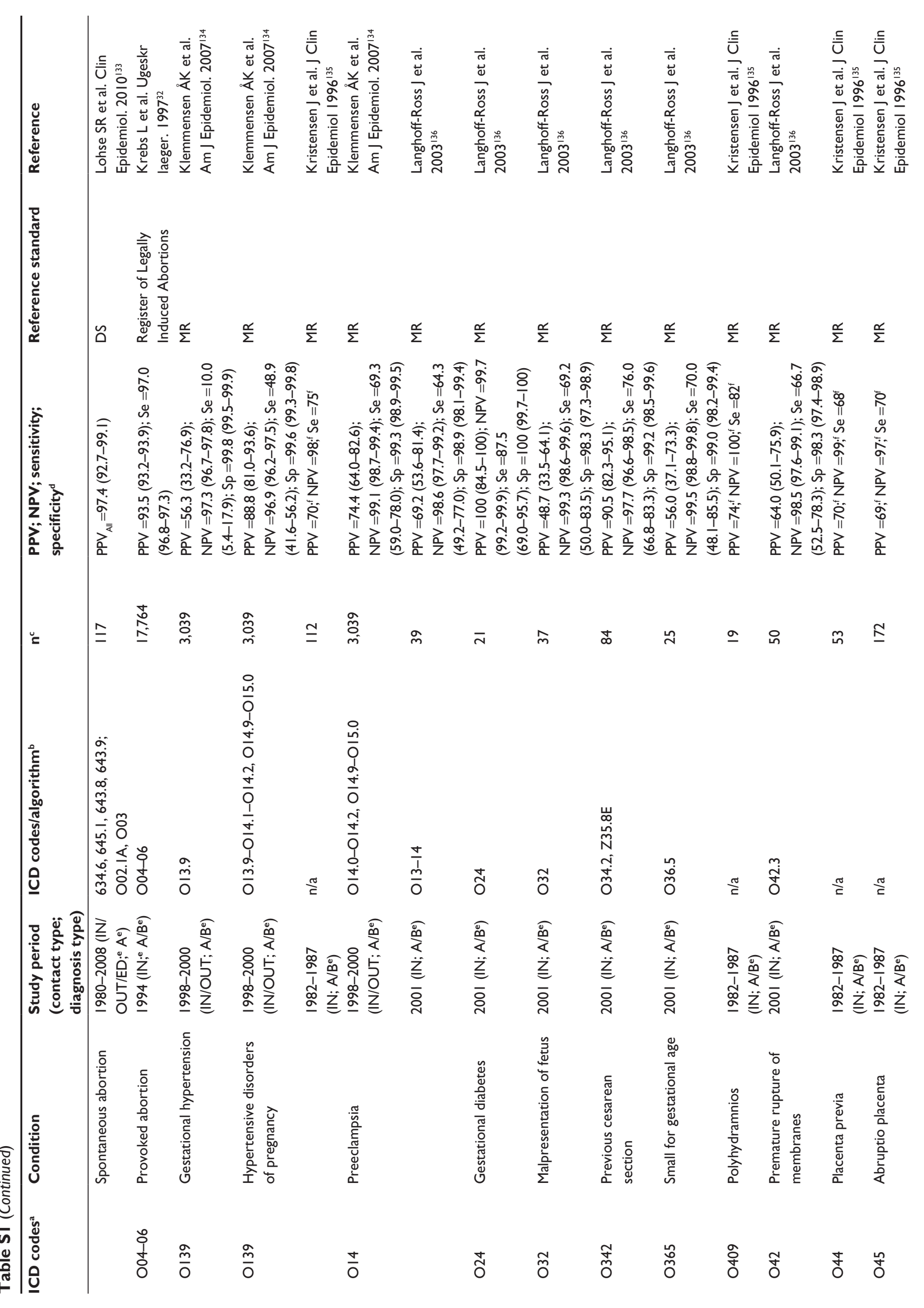




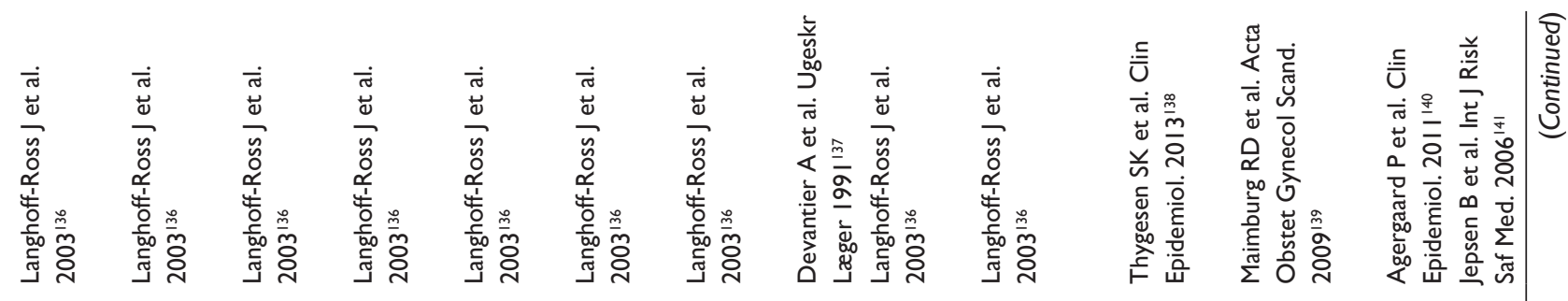

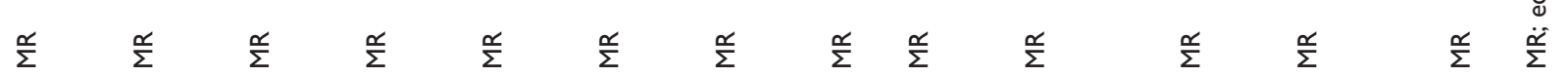

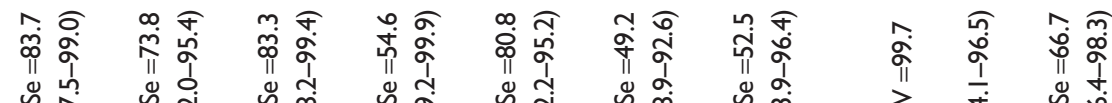

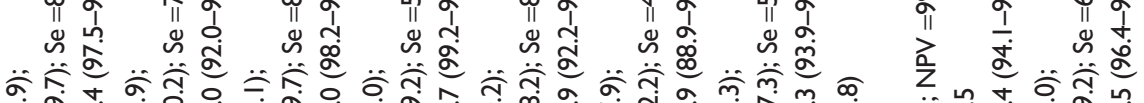
क人

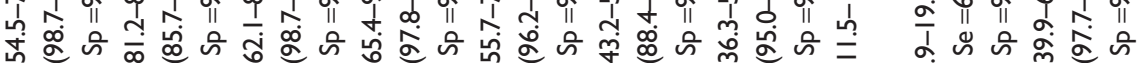

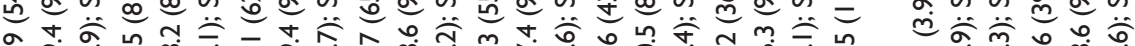

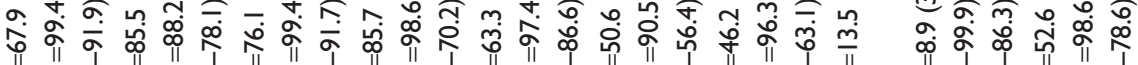

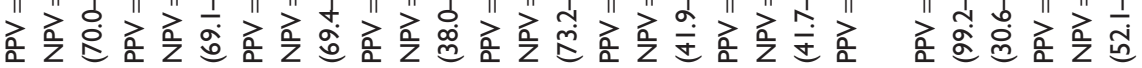

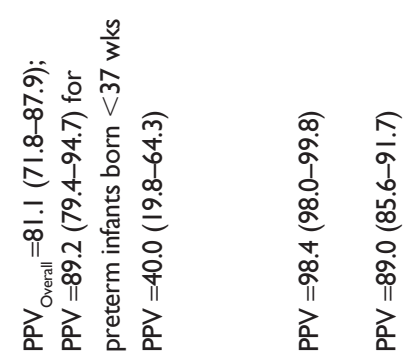

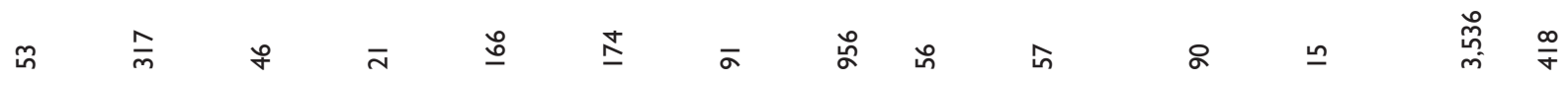

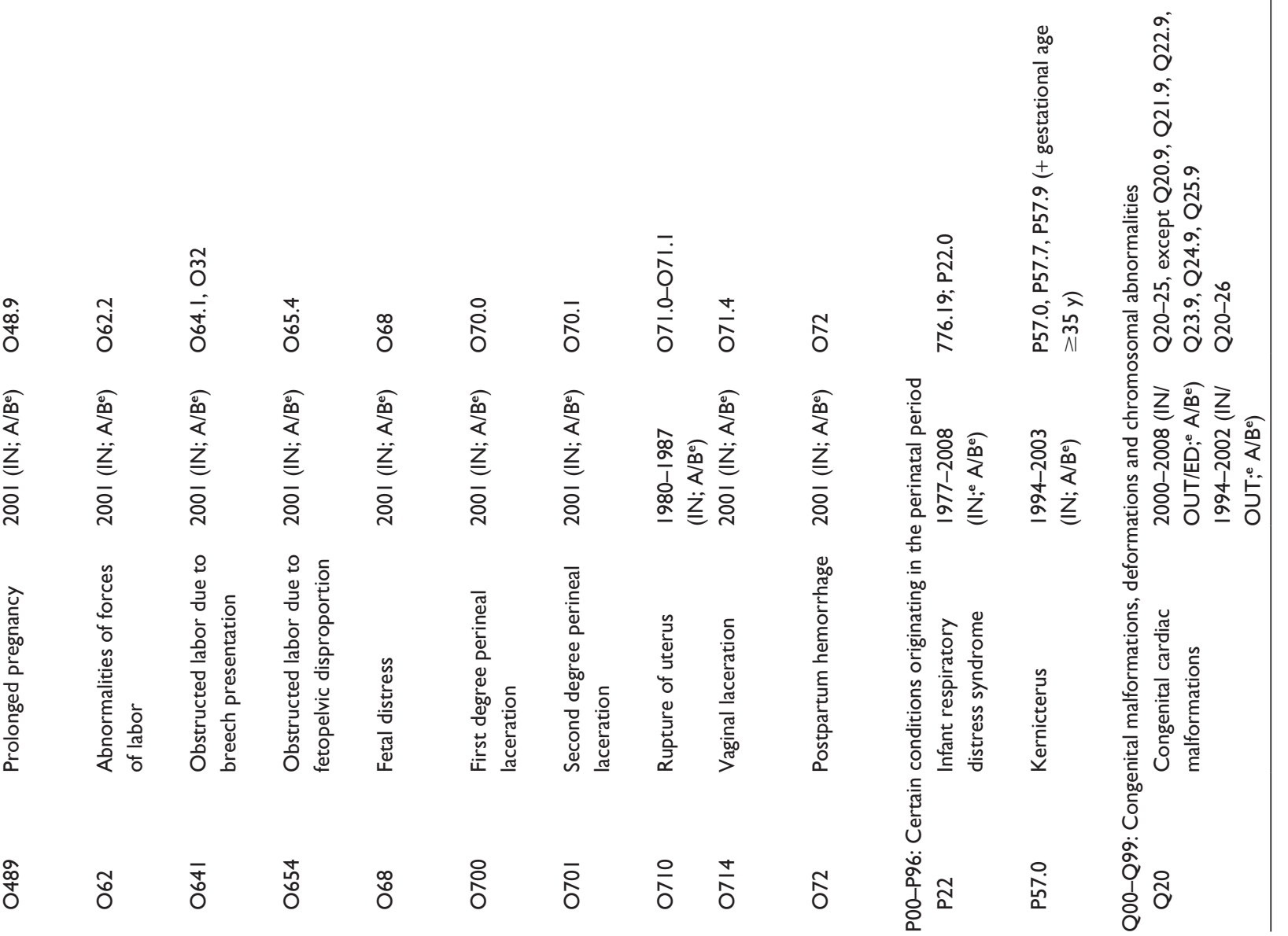




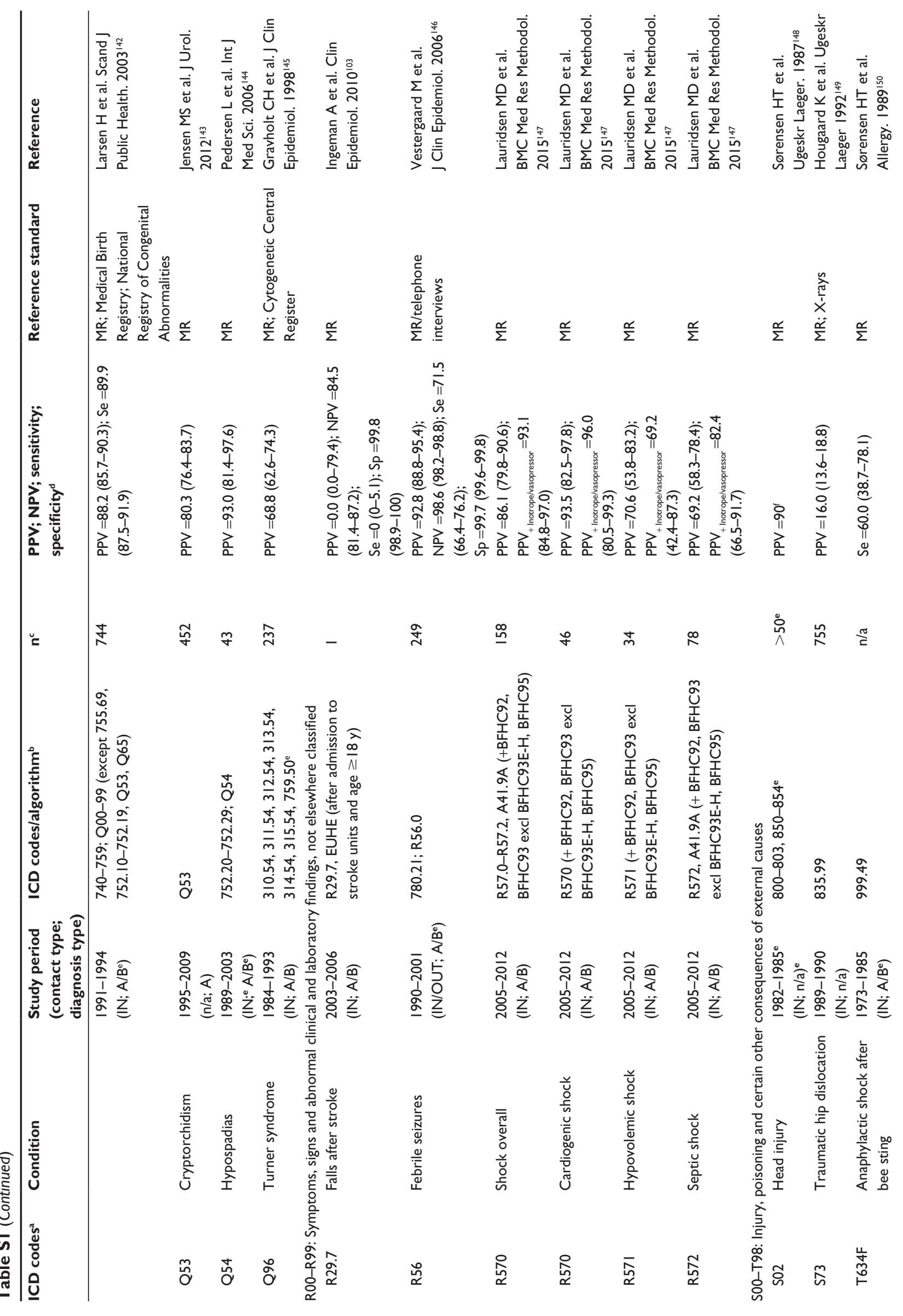




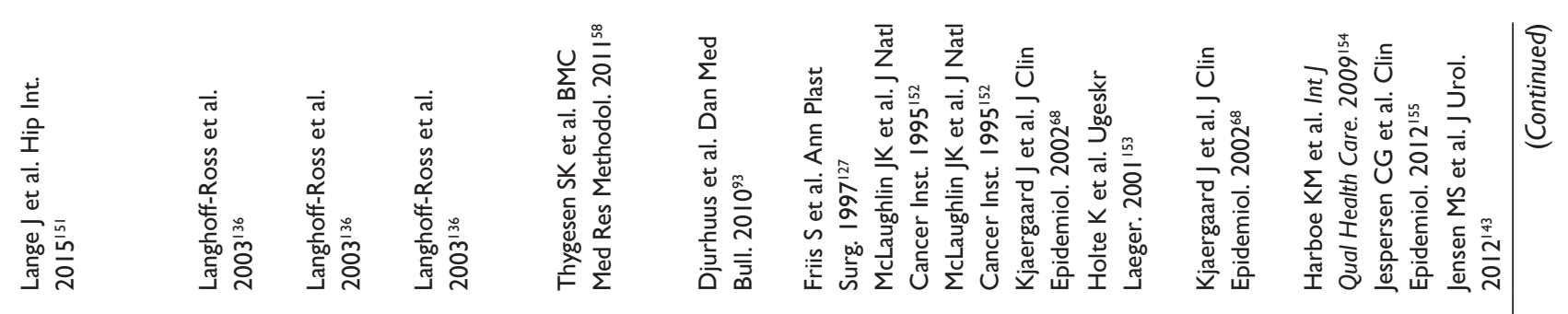

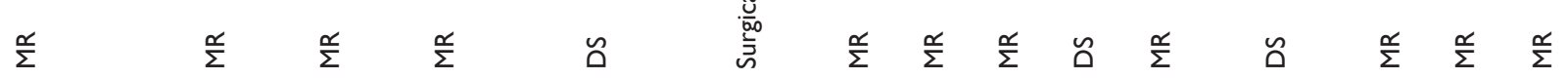

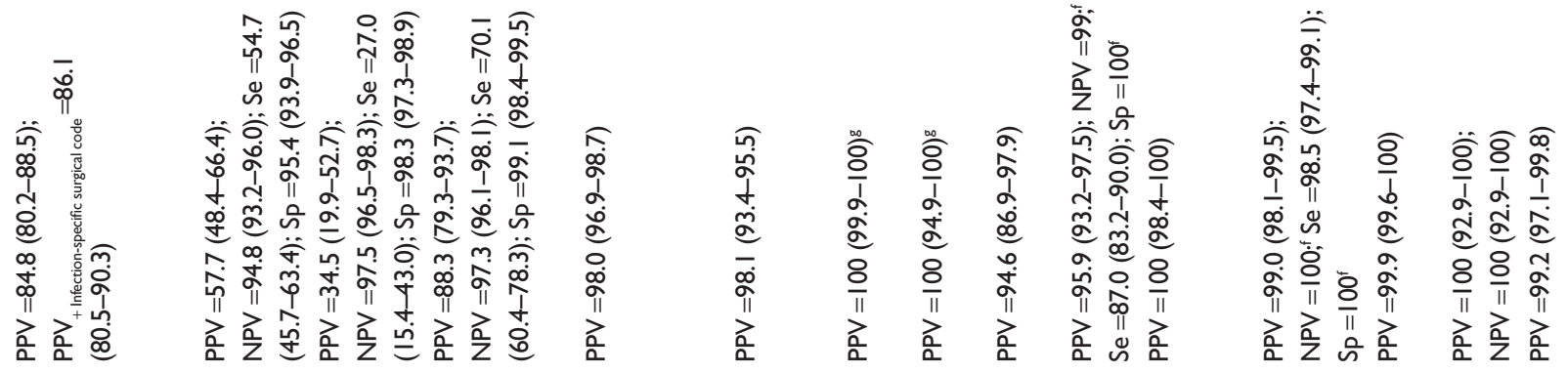

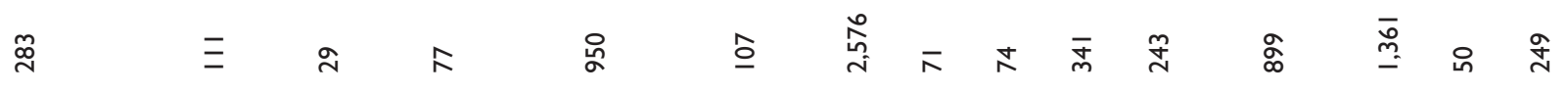

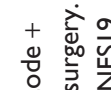

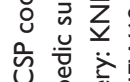

Z

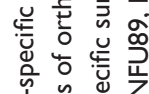

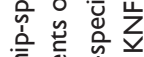

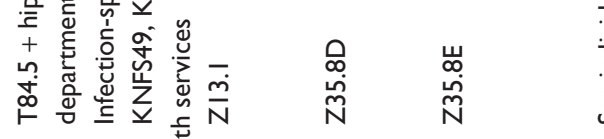

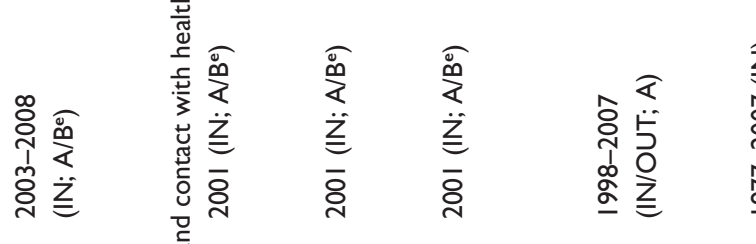

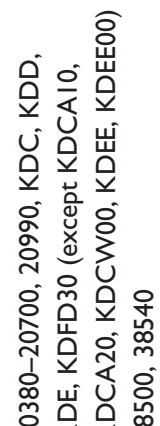

品岂过

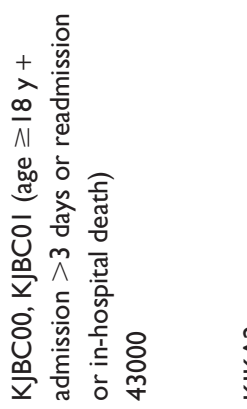

$\underline{\underline{z}}$

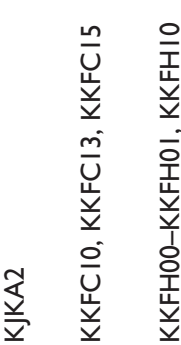

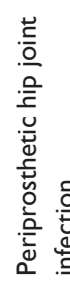

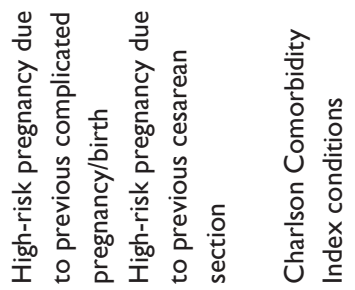

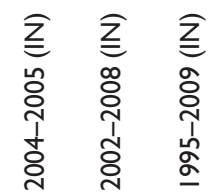

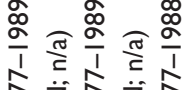

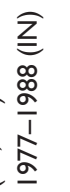
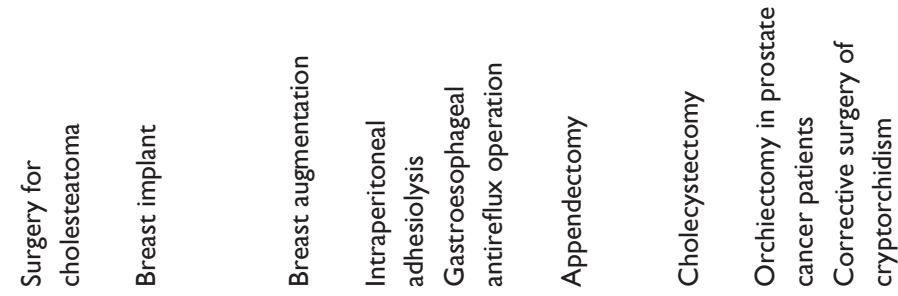

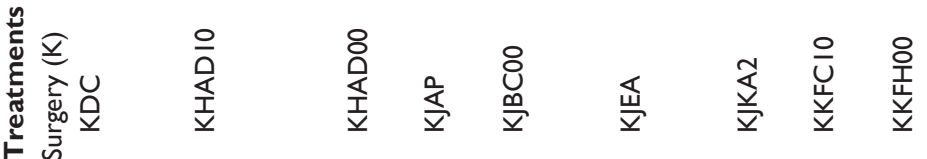




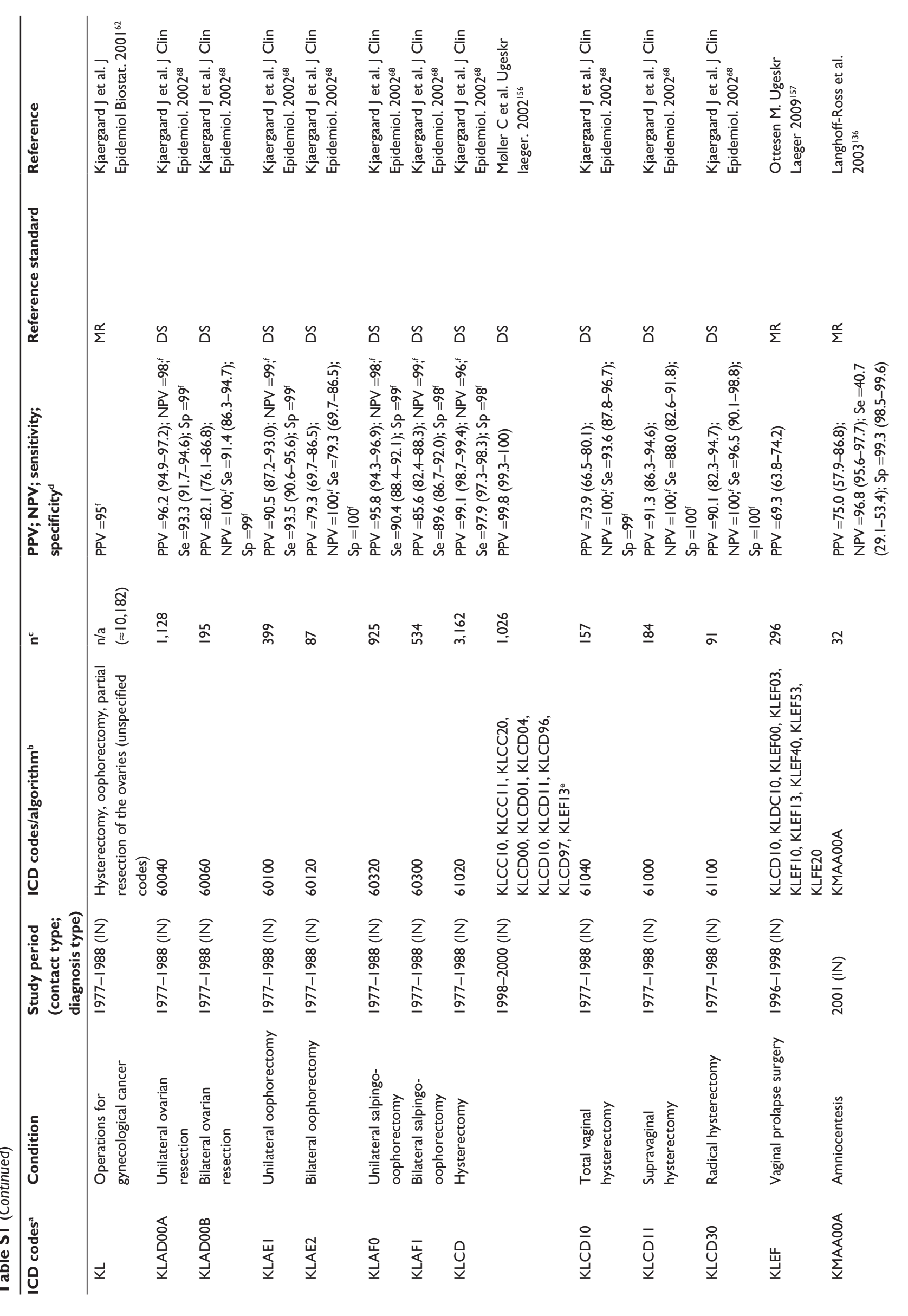


$\frac{\mathscr{\alpha}}{\Sigma} \quad \frac{\mathscr{\alpha}}{\Sigma} \quad \frac{\mathscr{N}}{\Sigma} \quad \frac{\mathscr{\alpha}}{\Sigma} \quad \frac{\mathscr{\alpha}}{\Sigma} \quad \frac{\mathscr{N}}{\Sigma} \quad \frac{\mathscr{N}}{\Sigma} \quad \frac{\mathscr{\alpha}}{\Sigma} \quad \frac{\mathscr{\alpha}}{\Sigma} \quad \frac{\mathscr{N}}{\Sigma} \quad \frac{\mathscr{N}}{\Sigma} \quad \frac{\mathscr{\alpha}}{\Sigma} \quad \frac{\mathscr{N}}{\Sigma} \quad \frac{\mathscr{N}}{\Sigma}$

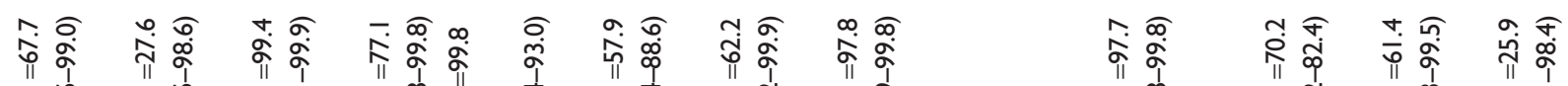

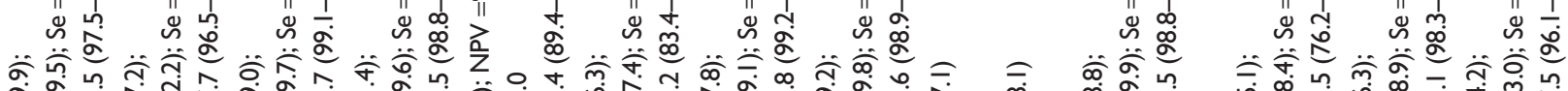

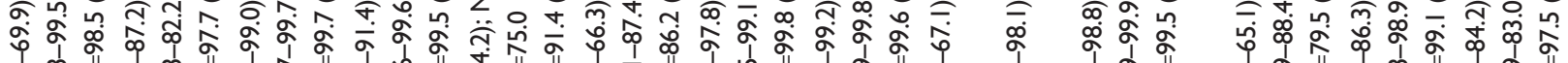
1

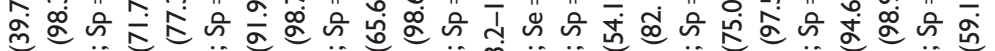

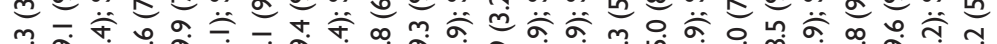

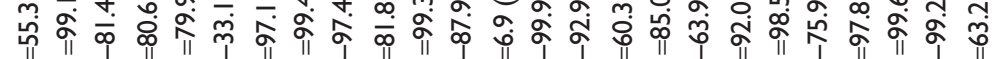

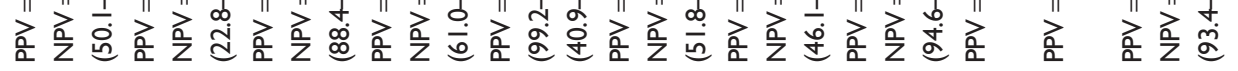

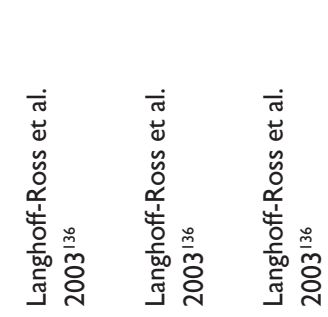

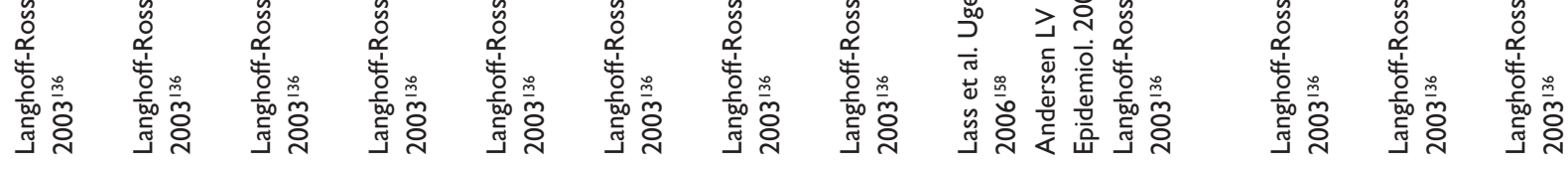

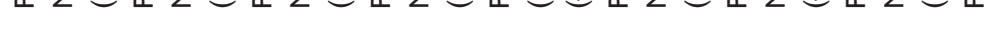

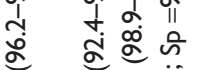

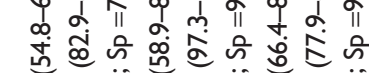

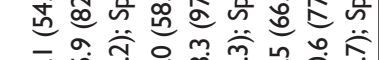

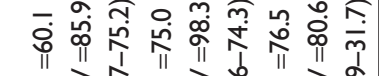

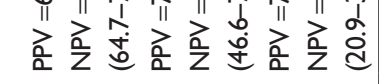

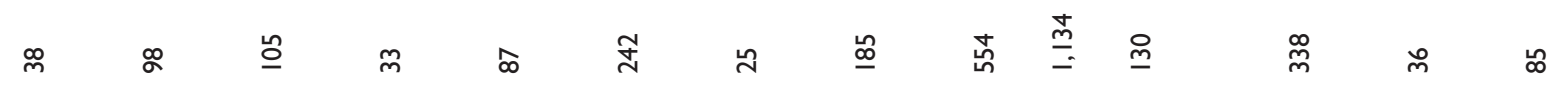

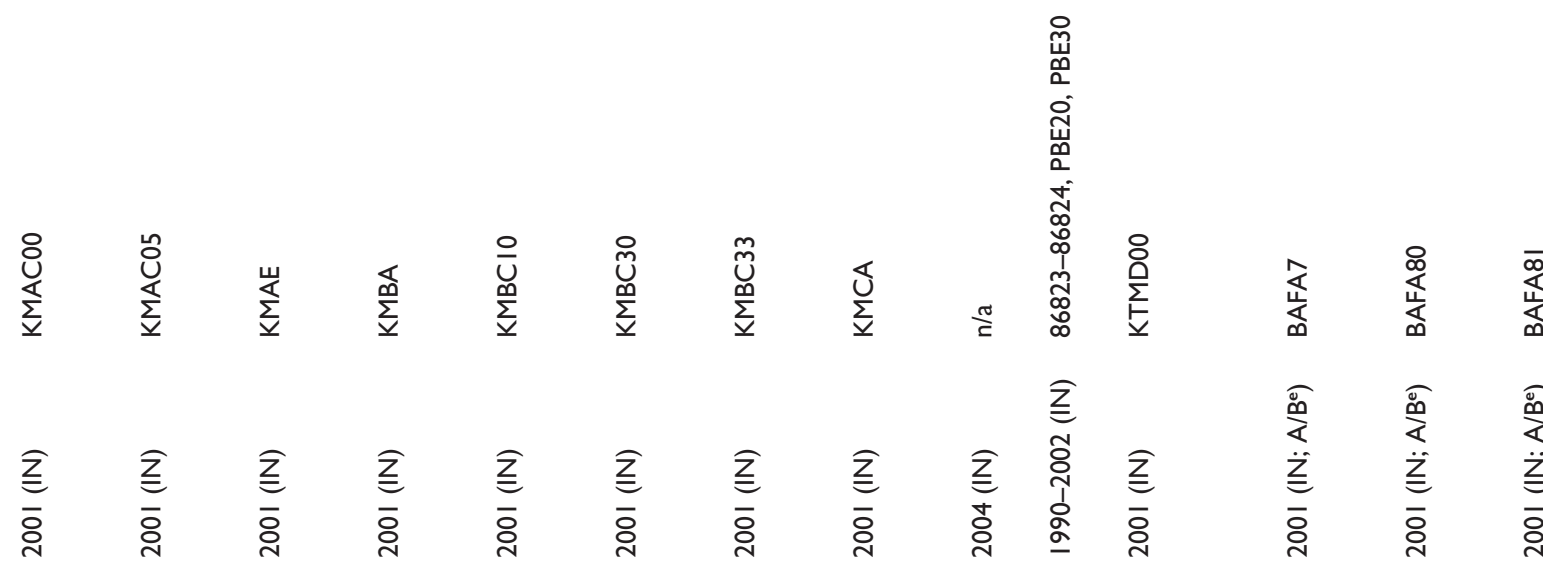

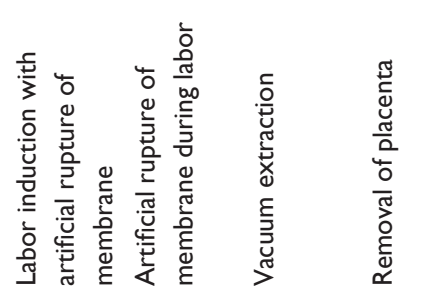


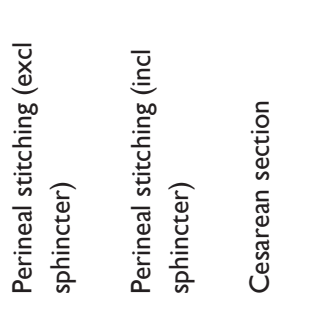

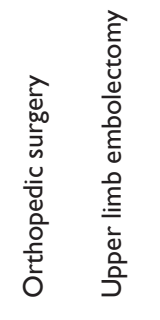

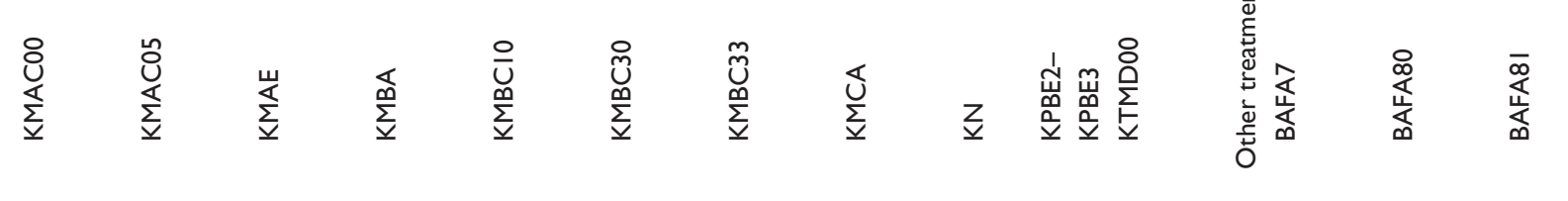




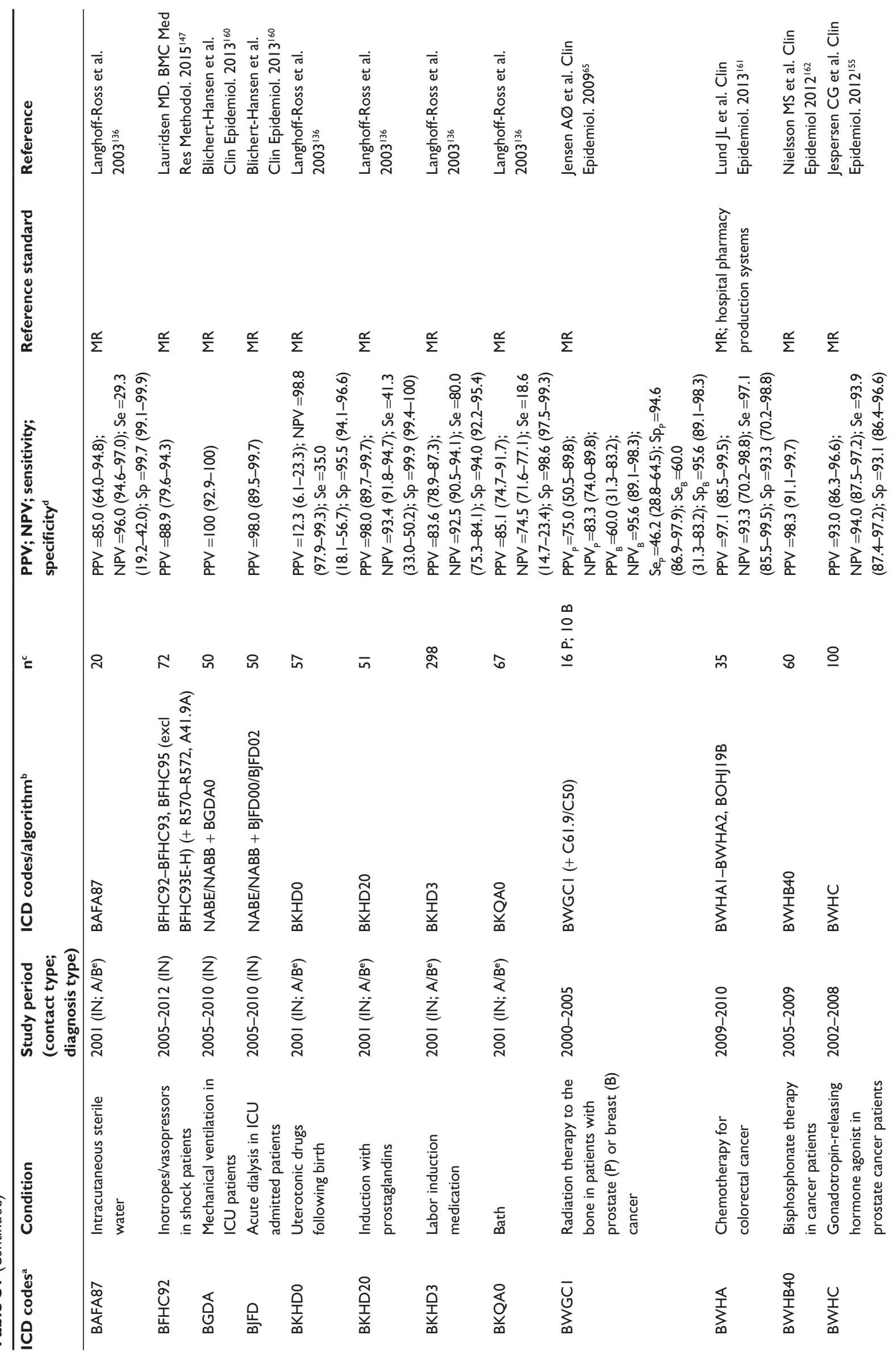




\begin{tabular}{|c|c|c|c|c|c|}
\hline 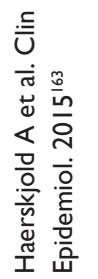 & 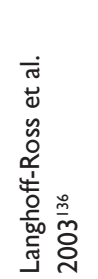 & 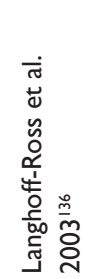 & 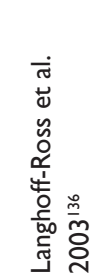 & 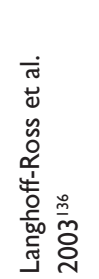 & 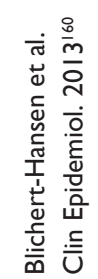 \\
\hline
\end{tabular}

$\frac{\stackrel{\alpha}{\Lambda}}{\stackrel{\ddot{x}}{\Sigma}}$

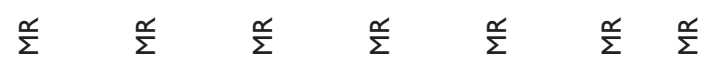

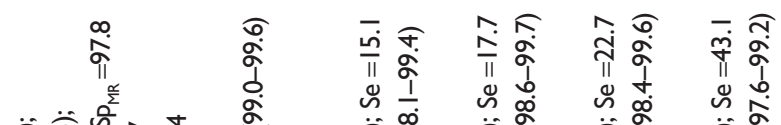

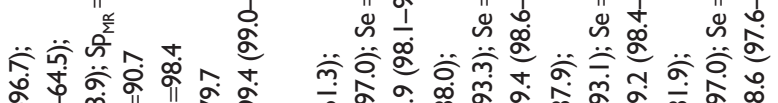

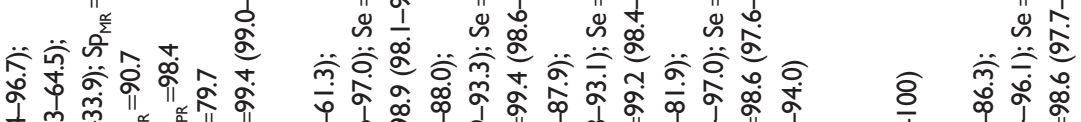

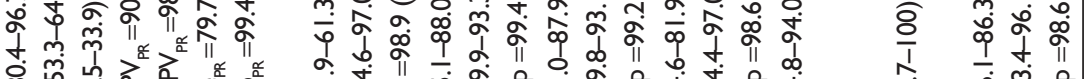
क्व

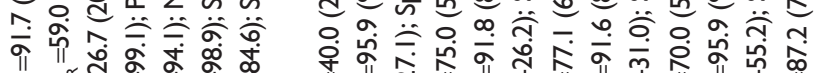

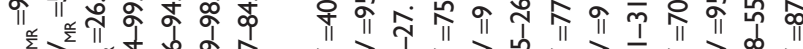

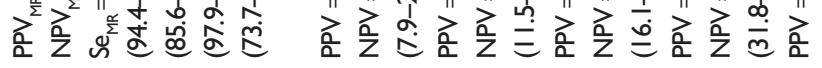

$\underline{\simeq}$

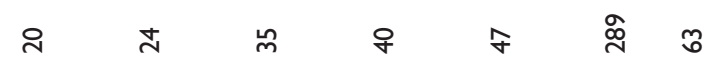

$\stackrel{0}{0}$
$\stackrel{0}{\circ}$
$\stackrel{\circ}{\Sigma}$

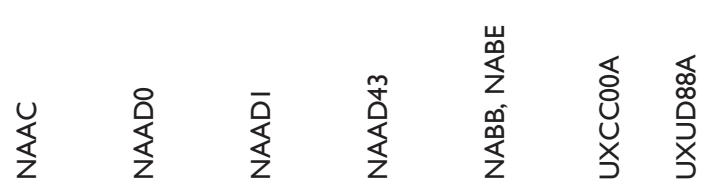

$\frac{\text { 을 }}{\text { ลे }}$

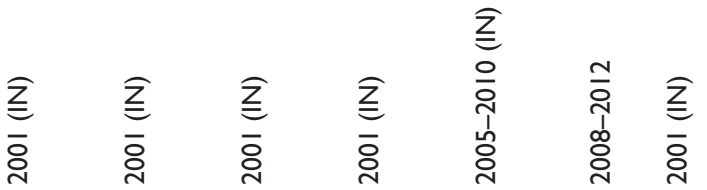

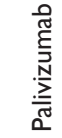

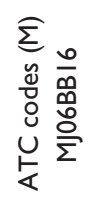

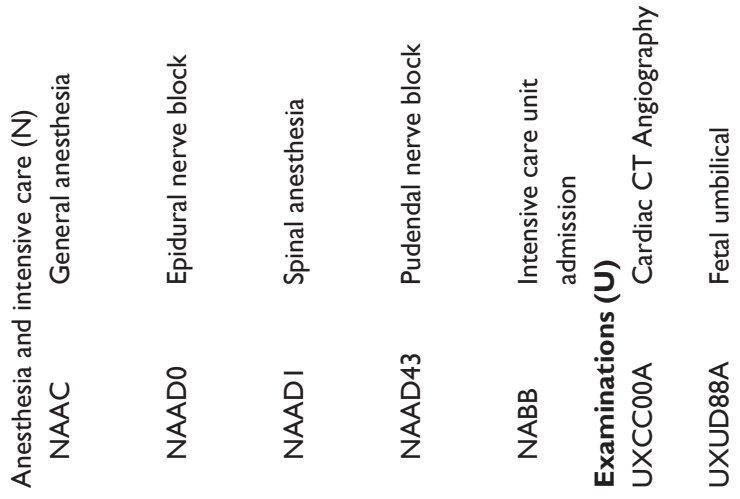




\section{Publish your work in this journal}

Clinical Epidemiology is an international, peer-reviewed, open access, online journal focusing on disease and drug epidemiology, identification of risk factors and screening procedures to develop optimal preventative initiatives and programs. Specific topics include: diagnosis, prognosis, treatment, screening, prevention, risk factor modification,

Submit your manuscript here: http://www.dovepress.com/clinical-epidemiology-journal systematic reviews, risk \& safety of medical interventions, epidemiology \& biostatistical methods, and evaluation of guidelines, translational medicine, health policies \& economic evaluations. The manuscript management system is completely online and includes a very quick and fair peer-review system, which is all easy to use. 